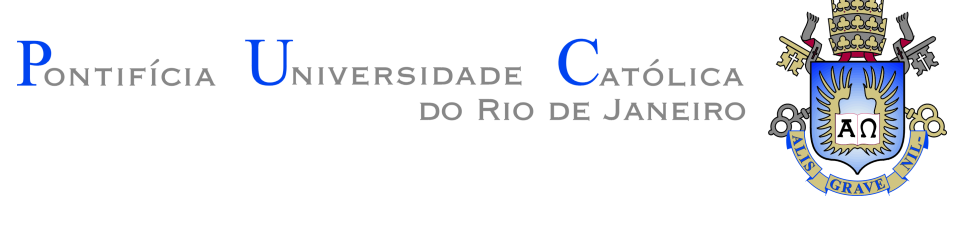

Marina Aguiar Palma

\title{
Essays on human capital formation from gestation to adolescence
}

Thesis presented to the Programa de Pós-graduação em Economia of PUC-Rio in partial fulfillment of the requirements for the degree of Doutor em Economia.

Advisor : $\quad$ Prof. Gabriel Lopes de Ulyssea Co-advisor: Prof. Naercio Aquino Menezes Filho 

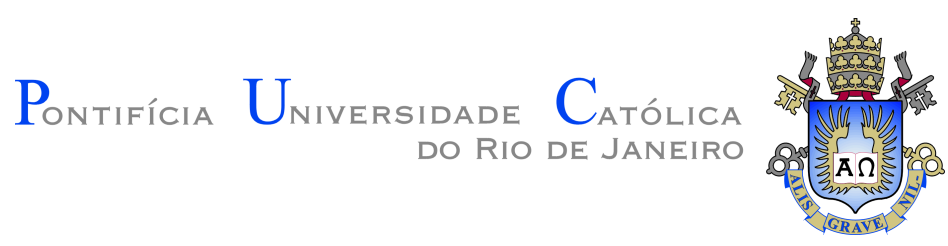

Marina Aguiar Palma

\section{Essays on human capital formation from gestation to adolescence}

Thesis presented to the Programa de Pós-graduação em Economia of PUC-Rio in partial fulfillment of the requirements for the degree of Doutor em Economia. Approved by the undersigned Examination Committee.

Prof. Gabriel Lopes de Ulyssea

Advisor

Departamento de Economia - PUC-Rio

Prof. Naercio Aquino Menezes Filho

Co-advisor

INSPER - INSPER

Prof. Pedro Carvalho Loureiro de Souza

Departamento de Economia - PUC-Rio

Prof. Juliano Junqueira Assunção

Departamento de Economia - PUC-Rio

Prof. Vladimir Pinheiro Ponczek

Escola de Economia de São Paulo - Fundação Getulio Vargas -

SP

Prof. Daniel Domingues dos Santos

Faculdade de Economia e Administração de Ribeirão Preto -

USP

Prof. Augusto Cesar Pinheiro da Silva

Vice Dean of the Centro de Ciências Sociais - PUC-Rio

Rio de Janeiro, September the 5th, 2017 
All rights reserved.

\section{Marina Aguiar Palma}

Graduated with B.Sc. in Economics from the Universiy of Nottingham, U.K. and obtained her M.Sc. Degree in Economics and International Economics from the Universiy of Nottingham, U.K.

Bibliographic data

Aguiar Palma, Marina

Essays on human capital formation from gestation to adolescence / Marina Aguiar Palma; advisor: Gabriel Lopes de Ulyssea; co-advisor: Naercio Aquino Menezes Filho. - Rio de janeiro: PUC-Rio, Departamento de Economia, 2017.

v., 111 f: il. color. ; $30 \mathrm{~cm}$

Tese (doutorado) - Pontifícia Universidade Católica do Rio de Janeiro, Departamento de Economia.

Inclui bibliografia

1. Economia - Teses. 2. Capital humano;. 3. Primeira infância;. 4. Gestação; . I. Lopes de Ulyssea, Gabriel. II. Aquino Menezes Filho, Naercio. III. Pontifícia Universidade Católica do Rio de Janeiro. Departamento de Economia. IV. Título. 


\section{Acknowledgments}

I would like to express my special appreciation to my advisor, professor Gabriel Ulyssea. You have offered not only essential research guidance but your trust and encouragement throughout this journey, all of this in the most thoughtful and kind manner, thank you. I would especially like to thank the professor Naercio Menezes Filho for having contributed immensely to my professional development. A special acknowledgement goes to professors and staff members at PUC-Rio who have strongly supported me academically and emotionally during my Doctorate years. A special mention goes to my professor at Nottingham University Marta Aloi, a role model and friend. I would also like to thank my committee members, professor Daniel dos Santos, professor Vladimir Ponczec, professor Pedro Souza and Professor Juliano Assunção for carefully thought suggestions.

I am indebted to my Doctorate friends, whom have made hard times bearable and hard subjects surpassable. Especially so to the coauthor of one of my articles, Soraya Román.

A special thanks to all my family who shared my dream and supported me to pursue it. Words cannot express how grateful I am to my mother, Eliana, my father, Michele, my mother in law Sandra, my sister Livia and my loving husband Bart. Most of all I would like to thank my son, Oscar.

I am grateful for the funding sources, Conselho Nacional de Desenvolvimento Científico e Tecnológico $(\mathrm{CNPq})$ and Coordenação de Aperfeiçoamento de Pessoal de Nível Superior (CAPES).

This thesis is paritally based on data from the study "Pelotas Birth Cohort, 1993" conducted by Postgraduate Program in Epidemiology at Universidade Federal de Pelotas with the collaboration of the Brazilian Public Health Association (ABRASCO). From 2004 to 2013, the Wellcome Trust supported the 1993 birth cohort study. The European Union, National Support Program for Centers of Excellence (PRONEX), the Brazilian National Research Council $(\mathrm{CNPq})$, and the Brazilian Ministry of Health supported previous phases of the study. 


\section{Abstract}

Aguiar Palma, Marina; Lopes de Ulyssea, Gabriel (Advisor); Aquino Menezes Filho, Naercio (Co-Advisor). Essays on human capital formation from gestation to adolescence. Rio de Janeiro, 2017. 111p. Tese de doutorado - Departamento de Economia, Pontifícia Universidade Católica do Rio de Janeiro.

This thesis consists of three essays on human capital formation from gestation to adolescence. The first two essays use the Pelotas 1993 Birth Cohort Study, from Pelotas, Brazil. The introductory essay looks at the relationship between household income at birth, late childhood, and late adolescence and variables that reflect human capital at age 18. Our results show that income at birth, during childhood and adolescence affect human capital formation. The estimate points at highest impacts being felt at childhood and birth years. These are consistent with the existence of family borrowing constraints, which are particularly pervasive in earlier years. In the second article we investigate the long-term determinants of human capital, from birth until early adulthood. We use the human skill formation model of (1) to estimate a production function of abilities at birth and at age 11. We follow to measure how these abilities combine to produce human capital outcomes. We find that parental investments have strong effects on all our dimensions of child development and at all ages. Further, we use exogenous shifts in income during pregnancy to show that income shocks can have long lasting effects on child abilities and hence on adult human capital levels. Finally, our results show complementarities between parental investments, parental abilities and child abilities. The third essay investigates Chile Crece Contigo a national-scale early childhood development policy implemented in Chile. The policy intended to improve children's development by enhancing their family environment and parents' childcare abilities. We estimate a production function of skills for pre- and post-ChCC cohorts, and find improvements in cognitive and non-cognitive skills for children under two years of age, and mixed results for children over two years of age. The increased abilities are not only associated with higher levels of parental investment but also with an increase in the average marginal product of this variable ${ }^{a}$.

${ }^{a}$ From the unpublished manuscript (2), written with Soraya Roman

\section{Keywords}

Human capital; Early childhood; gestation; 


\section{Resumo}

Aguiar Palma, Marina; Lopes de Ulyssea, Gabriel; Aquino Menezes Filho, Naercio. Ensaios sobre formação de capital humano da gestação até adolescência. Rio de Janeiro, 2017. 111p. Tese de Doutorado - Departamento de Economia, Pontifícia Universidade Católica do Rio de Janeiro.

em três ensaios sobre a formação de capital humano desde a gestação até a adolescência. Os dois primeiros ensaios utilizam o Coorte de Pelotas de 1993. O ensaio introdutório analisa a relação entre a renda familiar no nascimento, na infância tardia e no final da adolescência e variáveis que refletem o capital humano aos 18 anos. Nossos resultados mostram que a renda no nascimento, durante a infância e a adolescência, afetam a formação de capital humano. A estimativa aponta maiores impactos na infância e nos anos de nascimento. Estes são consistentes com a existência de restrições ao crédito familiares, que são particularmente fortes na infância. No segundo artigo, investigamos os determinantes de longo prazo do capital humano, desde o nascimento até o início da idade adulta. Usamos o modelo de formação de habilidades humanas de (1) para estimar uma função de produção de habilidades ao nascimento e aos 11 anos. Seguimos para medir como essas habilidades se combinam para produzir resultados de capital humano. Mostramos que os investimentos dos pais têm fortes efeitos em todas as nossas dimensões do desenvolvimento infantil e em todas as idades. Além disso, usamos mudanças exógenas na renda durante a gravidez para mostrar que choques de renda podem ter efeitos duradouros sobre as habilidades da criança e, portanto, sobre os níveis de capital humano adulto. Finalmente, nossos resultados mostram complementaridades entre investimentos parentais, habilidades parentais e habilidades infantis. O terceiro ensaio investiga o Chile Crece Contigo, uma política nacional de desenvolvimento da primeira infância implementada no Chile. A política é destinada a melhorar o desenvolvimento das crianças via ambiente familiar e as capacidades de cuidados dos pais. Nós estimamos uma função de produção de habilidades para coortes pré e pós-ChCC, e encontramos melhorias nas habilidades cognitivas e não cognitivas para crianças com menos de dois anos de idade e resultados mistos para crianças com mais de dois anos de idade. Este aumento de habilidades não são apenas associadas a níveis mais altos de investimento parental, mas também com um aumento no produto marginal médio desta variável ${ }^{a}$.

${ }^{a}$ Do manuscrito não publicado (2), escrito com Soraya Roman

\section{Palavras-chave}

Capital humano; Primeira infância; Gestação; 


\section{Table of contents}

1 Family income and child development from gestation to age 18: evidence from Brazil

$\begin{array}{ll}1.1 & \text { Introduction } \\ 1.2 & \text { Thedata }\end{array}$

$\begin{array}{lll}1.2 & \text { The data } & 14\end{array}$

$\begin{array}{ll}1.3 \text { Methodology } & 20\end{array}$

1.3.1 Income and human capital outcomes: mechanisms 20

$\begin{array}{lll}\text { 1.3.2 Regression analysis } & 22\end{array}$

1.4 Results 24

1.4.1 Human capital outcomes at adulthood 24

$\begin{array}{ll}1.4 .2 & \text { Intermediate outcomes } \\ 1.5 & 26\end{array}$

1.5 Conclusion 28

2 Human capital formation from gestation to age 18: evidence from Brazil 29

$\begin{array}{lll}2.1 & \text { Introduction } & 29\end{array}$

2.2 Structural modelling and estimation 31

2.2.1 The model 32

2.2.2 Estimation 34

2.2.2.1 A factor structure between measurements and latent variables 35

2.2.3 Endogeneity of parental investment in our production function 36

$\begin{array}{lll}\text { 2.2.3.1 Estimation Procedure } & 37\end{array}$

$\begin{array}{lll}2.3 & \text { Results } & 38\end{array}$

2.3.1 System of measurements and latent variables 38

2.3.2 Production function of child abilities 41

$\begin{array}{lll}2.4 & \text { Conclusion and next steps } & 47\end{array}$

3 A structural assessment of Chile Crece Contigo 49

3.1 Introduction 49

3.2 Chile Crece Contigo 51

3.3 Empirical strategy and Data 56

$\begin{array}{lll}\text { 3.3.1 Data } & 56\end{array}$

3.3.2 Empirical strategy 58

3.4 Structural modelling and estimation 61

$\begin{array}{lll}3.4 .1 & \text { The model } & 61\end{array}$

3.4.2 Estimation 63

3.4.2.1 A factor structure between measurements and latent variables 63

3.4.3 Endogeneity of parental investment in our production function 65

$\begin{array}{lll}\text { 3.4.3.1 Estimation Procedure } & 66\end{array}$

$\begin{array}{lll}3.5 & \text { Results } & 67\end{array}$

3.5.1 System of measures and latent variables 67

$\begin{array}{ll}\text { 3.5.2 Production functions } & 70\end{array}$

$\begin{array}{ll}\text { 3.5.3 Model fit and simulation exercises } & 77\end{array}$

$\begin{array}{ll}3.6 \text { conclusion } & 79\end{array}$

$\begin{array}{ll}\text { Bibliography } & 81\end{array}$ 
$\begin{array}{lll}\text { A } & \text { Chapter } 1 \text { - Additional results } & \mathbf{8 7}\end{array}$

A.1 A life-cycle model of human capital 87

$\begin{array}{lll}\text { B } & \text { Chapter 2 - Additional results } & 105\end{array}$

C Chapter 3 - Additional results 108

C.1 Chile Crece Contigo 108 


\section{List of figures}

Figure 1.1 Family income and human capital outcomes at age $18 \quad 25$

Figure 1.2 Family income and human capital outcomes at age $11 \quad 27$

Figure 3.1 Timeline of the implementation of the social protection system

Figure 3.2 Sample distribution

Figure 3.3 ChCC predicted effect along parental cognition distribution 78

Figure 3.4 Proportion of ChCC quantity effect along parental cognition distribution

Figure A.1 Real value of national minimum wage by date of birth 91

Figure B.1 Distribution of latent variables 105

Figure C.1 Distribution of latent variables - Age 18-23 months 110

Figure C.2 Distribution of latent variables - Age 36-47 months 111 


\section{List of tables}

Table 1.1 Selected demographic and socio-economic statistics of Brazil and Pelotas- 2010

Table 1.2 Descriptive Statistics at birth 16

$\begin{array}{lll}\text { Table 1.3 } & \text { Descriptive Statistics at age } 11 & 18\end{array}$

$\begin{array}{lll}\text { Table 1.4 Descriptive Statistics at age 18 } & 19\end{array}$

Table 2.1 Signal percentage of measurements- latent variables at birth 40

Table 2.2 Signal percentage of measurements- parental latent variables 40

Table 2.3 Signal percentage of measurement of latent variables at age $11 \quad 42$

Table 2.4 Equations on the determinants of investment 43

Table 2.5 CES Production function of children's abilities 44

Table 2.6 CES Production function of human capital outcomes 46

Table 3.1 Coverage and expansion of Chile crece contigo 52

Table 3.2 Instruments and factors to determine vulnerability 55

Table 3.3 Outcomes of Chile crece contigo for families in the public health system $\quad 56$

Table 3.4 Descriptive Statistics - Socio-demographic characteristics 58

Table 3.5 Descriptive Statistics - Potential programme outcomes 59

Table 3.6 Percentage of information per measure of latent variables 69

Table 3.7 Mean difference of latent variable before and after ChCC 70

Table 3.8 Investment functions $\quad 71$

$\begin{array}{lll}\text { Table } 3.9 & \text { External Socio-emotional skills } & 73\end{array}$

Table 3.10 Internal Socio-emotional skills $\quad 74$

Table 3.11 Cognitive skills $\quad 75$

Table 3.12 Differences in production functions parameters 76

Table 3.13 Observed and predicted value of children abilities - Age 18-23 months 77

Table 3.14 ChCC effect on children abilities with and without a $\begin{array}{ll}\text { change in production function } & 79\end{array}$

Table A.1 Attrition $\quad 91$

Table A.2 Schooling at age $18 \quad 92$

Table A.3 Probability of attending a post-secondary institution at age $18 \quad 93$

Table A.4 Probability of completing Secondary Education at age 1894

Table A.5 Probability of having at least one child at age $18 \quad 95$

Table A.6 Health problems index at age $18 \quad 96$

$\begin{array}{lll}\text { Table A.7 } & \text { Schooling at age } 11 & 97\end{array}$

Table A.8 SDQ conduct problems score age 11 98

Table A.9 SDQ hyperactivity and attentional problems score age 1199

Table A.10 SDQ emotional problems score age $11 \quad 100$

Table A.11 SDQ peer relations problems score age 11

Table A.12 SDQ pro-social behaviour score age 11 
Table A.13 SDQ internalising scores age 11

Table B.1 Endogenous CES Production function of children's abilities106

Table B.2 Nested CES Production function of children's abilities 107

Table C.1 ChCC Statistics

108

Table C.2 2010 Descriptive Statistics - Socio-demographic characteristics

Table C.3 2012 Descriptive Statistics - Socio-demographic characteristics 
All happy families are alike; each unhappy family is unhappy in its own way.

Leon Tolstoy, Anna Karenina. 


\section{Family income and child development from gestation to age 18: evidence from Brazil}

\section{1 Introduction}

The relationship between family income and human capital has been a subject of intense debate in social sciences. There is evidence showing that parental income at earlier stages of childhood have greater impacts on human capital when compared to income later stages of $(3,4,5)$ and evidence that exogenous shifts in family income affect child development (7), (8). (9) states that besides the importance of early-life income, other "stylised facts" are that the estimated impact of family income appears to be larger for achievement and cognitive outcomes than for measures of health and socioemotional abilities as well as for children in low-income families when compared to those high-income families. Note that the final stylised fact points at the importance of studying this relationship outside the group of high-income countries. In economics, this relationship is discussed around the concept of financial market imperfections ${ }^{1}$. There is an extensive literature debating the effects of credit constraints on University attendance. (11), (12), (13), (14), suggest that University attendance decisions are explained to a greater extent by current abilities than by current family income. This raised the question on whether family credit constraints at earlier stages of child's life, which affect abilities formations, are more pervasive than at later stages. In fact, (15) shows that more families face credit constraints early in a child's lifecycle when compared later years and that early constraints have compounding effects due to complementarities between investments in early and late years.

We build on this literature by analysing the relationship between family income at different points in a child's life-cycle and child and adult achievement in a middle-income country scenario. We use The Pelotas 1993 Birth Cohort Study, from Pelotas, Brazil, which follows 5,249 children from birth to age 18. Family income is measured at three points in the child's life-cycle: income at

\footnotetext{
${ }^{1}$ Heckman, in (10), notes that a further constraint on reaching optimal levels of parental investments in children is the inability of children to choose their parents.
} 
Chapter 1. Family income and child development from gestation to age 18: evidence from Brazil

birth, income at age 11 and income at age 18. Our results show that income at birth, during childhood and adolescence affect the human capital measures such as schooling and health in early adulthood even after we use a wide range of controls. The controls went beyond the usual socio-economic and demographic variables to include child and parental abilities as well as parental investments. The fact that explanatory power of parental income remained after the inclusion suggests a stronger relationship is indeed present in middleincome countries. Secondly, the estimate points at the highest impacts being felt at childhood and birth years. We take this as evidence suggesting the existence of family borrowing constraints, which are particularly pervasive in earlier years. These are in line with stylised facts one and three above. Contrary to stylised fact two we find stronger associations between parental income and schooling vis-à-vis health but not socio-emotional abilities.

This chapter is organised as follows: we begin with data description, which will also form the basis of our second chapter. The second section offers our methodology and it is followed by results from our regression analysis. We finalise with conclusions.

\section{2 \\ The data}

Chapter one and two of this thesis are based on The Pelotas 1993 Birth Cohort Study, a longitudinal survey of all live births in urban Pelotas in 1993. The survey includes all newborns delivered in the five maternity hospitals of the city. Information was obtained on 5,249 live births and 55 foetal deaths, representing over $99 \%$ of all births that occurred in urban Pelotas between 1st of January and 31st of December 1993. Further surveys were carried out with all cohort members in 2004-5, when they had 10-12 years of age, and in 2011, when they had 17-18 years of age. These are the time periods used in this thesis ${ }^{2}$.

During the perinatal wave mothers were interviewed at hospital for information on pre-natal and perinatal behaviour, socio-economic characteristics of the family and newborn health. All newborns were weighted and measured within 24 hours of birth. All measurements were obtained using standardised techniques practised through training sessions in the maternity hospitals. The 2004-5 questionnaire was divided into three blocks. In the first block mothers were asked about family characteristics, parental variables and child morbidity. The second and third blocks contained questions for the pre-adolescents. The difference between them is that the third block was confidential questionnaires

${ }^{2}$ For more details on the 1993 birth cohort study see (16) 
with questions on alcohol and drug consumption and sexual activity amongst others. The 2011 wave was composed of general, confidential and diet questionnaires. Further, in that year cohort members undertook medical evaluations, psychometric and cognition tests ${ }^{3}$

We must emphasise our middle-income setting. There exist few cohort studies from low and middle-income countries (16). In fact, the preceding Pelotas 1982 Birth Cohort Study is the largest and longest running birth cohort study in a developing country (17). Further, previous studies on human capital formation in childhood and adolescence in developing countries have relied on subsets of populations, as (18), (19) and (20) which focuses on poorest families in Colombia, India and Peru and Ethiopia respectively. We have the entire population, not a subset, of all people born in Pelotas, Brazil in 1993.

Pelotas is a city located in the state of Rio Grande do Sul, the southernmost state of Brazil. The city's socio-economic statistics, as shown in table 1.1, are similar to Brazilian averages, albeit variance distributions are shown to be different. In terms of child poverty, the percentages of children living with less of two dollars per day in Pelotas is $42 \%$ while for the whole of Brazil this percentage is $49 \%$. The proportion of children living in extreme poverty in Pelotas is half of the proportion found in the entire country.

Table 1.1: Selected demographic and socio-economic statistics of Brazil and Pelotas- 2010

\begin{tabular}{lcc}
\hline \hline Variable & Brazil & Pelotas \\
\hline Household income p.c R $\$$ month & 794 & 894 \\
Life expectancy at birth & 73.9 & 75.6 \\
Completed years of education & 9.6 & 9.9 \\
Gini coefficient & 0.60 & 0.54 \\
Children living poverty & 0.49 & 0.42 \\
Children living in extreme poverty & 0.11 & 0.05 \\
\hline \hline
\end{tabular}

We now look at some descriptive statics from our sample.In order to ensure we are measuring changes in purchasing power our income data was deflated using the Brazilian Consumer Price Index ${ }^{4}$. Our population is mostly

${ }^{3}$ We do not have access to entire information set from the 2011 wave as yet.

${ }^{4}$ We used the Brazilian Consumer Price Index Índice Nacional de Preços ao Consumidor downloaded from the Brazilian Institute of Applied Economic Research IPEA for the city of Porto Alegre, the capital of the State of Rio Grande do Sul. We used monthly inflation in the year 1993 and average yearly inflation in the remaining years. In the year of 1993 we have turned the data collected in terms of minimum salaries into nominal income at the currency of the period. In our period of study Brazil changed currencies in two occasions: in August 1993 the country moved from the Cruzeiro to the Cruzeiro Real and in July 1994 
white, specifically $77 \%$ of mothers are white. In our sample average age at birth is 26 years for mothers and 30 years fathers. In terms of education, table 1.2 shows that both father's and mother's completed just under 7 years of education. Pre-natal behaviour shows that $33 \%$ of mothers smoked while pregnant and 5\% drank any alcohol. Further mother's attended on average 8 pre-natal visits, with the first one happening in the first trimester, as recommended. Most women in our sample gave birth in a public hospital, $87 \%$, and had a vaginal delivery, $69 \%$. The majority of babies in our sample are healthy: average birth weight is $3.156 \mathrm{kgs}$ and one minute Apgar scores have a mean of 8.4 points ${ }^{5}$. We also included the following natal measurements which are used in our next chapter: height, head circumference, abdominal circumference, thoracic circumference and the score on test of approximate gestation age of the baby ${ }^{6}$.

Table 1.2: Descriptive Statistics at birth

\begin{tabular}{lccccc}
\hline \hline \multicolumn{5}{c}{ Descriptive Statistics at birth } & \\
\hline Variable & Obs & Mean & Std.Dev & Min & Max \\
\hline Household income 1993 in min. wage & 5136 & 4.29 & 0.88 & 0 & 88.2 \\
Mother's age & 5248 & 26.00 & 6.41 & 13 & 47 \\
Father's age & 5168 & 29.55 & 7.74 & 15 & 77 \\
Mother's education & 5013 & 6.73 & 3.55 & 0 & 19 \\
Father's education & 4659 & 6.83 & 3.51 & 0 & 17 \\
Mother is white & 5247 & 0.77 & 0.42 & 0 & 1 \\
Number of pre-natal visits & 5238 & 7.67 & 3.68 & 0 & 20 \\
Month of first pre-natal visit & 4733 & 2.65 & 1.86 & 0 & 9 \\
Pregnancy weight gain-distance & 4799 & -2.72 & 3.45 & -26.5 & 0 \\
Smoked during pregnancy & 5249 & 0.33 & 0.47 & 0 & 1 \\
Drank alcohol during pregnancy & 5249 & 0.05 & 0.22 & 0 & 1 \\
High Blood Pressure in pregnancy & 5143 & 0.16 & 0.36 & 0 & 1 \\
Diabetes in pregnancy & 5129 & 0.02 & 0.14 & 0 & 1 \\
Mother's weight before pregnancy & 5138 & 58.18 & 10.49 & 33 & 137 \\
Mother's height & 5203 & 159.80 & 6.76 & 125 & 188.5 \\
Male & 5248 & 0.50 & 0.50 & 0 & 1 \\
Caesarian birth & 5249 & 0.31 & 0.46 & 0 & 1 \\
Birth in the public-sector & 5249 & 0.87 & 0.34 & 0 & 1 \\
Weight at birth & 5232 & 3156.59 & 549.40 & 500 & 5500 \\
Head circumference at birth & 4942 & 34.63 & 1.65 & 21.5 & 44.0 \\
Abdominal circumference at birth & 4888 & 28.63 & 2.58 & 17.0 & 43.5 \\
Thoracic circumference at birth & 4944 & 33.32 & 2.20 & 20.0 & 51.5 \\
Length at birth & 4935 & 48.77 & 2.40 & 30.5 & 57.5 \\
Apgar Score 1 min & 3813 & 8.37 & 1.50 & 0 & 10 \\
Dubowitz score of gestational age & 5139 & 52.9 & 5.81 & 11 & 69 \\
Baby in ICU & 5241 & 0.04 & 0.20 & 0 & 1 \\
\hline \hline
\end{tabular}

We follow to show the statistics of our sample when the children were around 11 years of age. We can see that over half of our sample has completed it moved to the Real.

${ }^{5}$ Apgar 1 minute score are based on breathing effort, heart rate, muscle tone, reflexes, skin colour of the baby one minute after birth. An Apgar of 7 points or higher is a considered a healthy score. From The US National Library of Medicine on https : //www.nlm.nih.gov/medlineplus/ency/article/003402.htm accessed on 28 March 2017

${ }^{6}$ We use the Dubowtiz score of gestational age. The Dubowitz/Ballard scores contains 6 exercises which measure newborn neuromuscular maturity and 6 questions which measure newborn physical maturity. Each exercise/question is given scores from -1 to 5 . The final score is the sum of all subscores and gives an estimation of newborn gestational age 
four years or more of education ${ }^{7}$. Similarly, $63 \%$ children, had not failed any grades in school at age 11 . In the survey, $4 \%$ of children have reported to undertake paid work. Children have reported reading magazines, new papers or books on average 2.5 days in a week. In the confidential questionnaire children categorised the number of times in the past six months they have received physical punishment into four groups: never, 1-2 times, 3-5 times, 6 or more. We see that the majority of children were not subjected to physical punishment. In terms of health, $28 \%$ of cohort members have asthma, less than $0.1 \%$ have diabetes while at the interview $12 \%$ had a systolic blood pressure of 120 or higher.

The study also offers an assessment of the child's mental health through the Strengths and Difficulties questionnaire (SDQ). The SDQ was answered by mothers and children themselves. We decided to use the mother's answers as those contained less missing values. The questionnaire is divided into 5 scales: emotional problems, conduct problems, hyperactivity, peer relations and prosocial behaviour ${ }^{8}$.

The SDQ questionnaire is also divided into externalising, composed of conduct problems and hyperactivity, and internalising scores, composed of peer relations and emotional problems. The field of child psychology has long distinguished between "internalising" and "externalising" disorders (21), we follow this separation in our analysis both in all chapters of this thesis. The former reflecting the child negatively acting on the external environmental stimuli and the latter reflecting problems with the child's internal psychological environment. Examples of externalising behaviour problems are aggressiveness, attentional deficits and hyperactivity while examples of internalising behaviour include anxiety and depression. We are particularly interested in the external component of SDQ as external behaviour problems are linked to executive functioning of the brain $(22,23)$. Executive function consists of four principle dimensions: i) attentional control ii) information processing iii) cognitive flexibility iv) goal setting. All contribute to determining a child's cognitive function behaviour, emotional control and social interaction. Attentional control, subdivided into processes of selective attention, self-regulation, self-monitoring and inhibition, appears to emerge in infancy and develop in early-childhood.

${ }^{7}$ On average children had completed the third grade which equates to 4 years of primary schooling in Brazil at the time.

${ }^{8}$ For the first four scales a higher score means a worse mental health condition, while for the last item higher scores represent positive behaviour. The overall score, is made of the sum of all scores where higher points indicate worse mental health. Each scale is given a score of maximum ten points giving a total score of fifty points. A score of 17 points or less is considered to be normal. Please see more on http://www.sdqinfo.com/ accessed on 28 March 2016 
Chapter 1. Family income and child development from gestation to age 18: evidence from Brazil

The remaining three dimensions develop and mature at later stages of childhood (24). Although the early-childhood development literature has not distinguished between "internalising" and "externalising" mental health, it has begun to measure EF as a separate skill from socio-emotional and cognitive skills $(25,26)$.

In our 2004 wave, we have variables of parental health as well as variables that measure the relationship between the child and their parents. We also control for the psychological well-being of the mother through The Self Reported Questionnaire-20 (SQR-20), which is an instrument measuring symptoms associated with neurotic disorders ${ }^{9}$.

Table 1.3: Descriptive Statistics at age 11

\begin{tabular}{lccccc}
\hline \hline & Descriptive Statistics & at 11 yrs & & & \\
\hline Variable & Obs & Mean & Std.Dev & Min & Max \\
\hline Household income 2004 R\$ $\$ 3973$ & 1171 & 2392 & 15 & 53810 \\
Mother's Psychological Score & 4402 & 0.36 & 0.21 & 0 & 1 \\
Psychological problems mother or father & 4386 & 0.35 & 0.48 & 0 & 1 \\
Child is black or brown & 4420 & 0.28 & 0.45 & 0 & 1 \\
Last grade completed & 4442 & 3.51 & 1.15 & 0 & 7 \\
Number grade retentions & 4407 & 0.61 & 0.98 & 0 & 6 \\
Child works & 4441 & 0.04 & 0.20 & 0 & 1 \\
Child's height (female) & 2257 & 146.82 & 7.90 & 111 & 171.1 \\
Child's height (male) & 2185 & 144.84 & 7.76 & 119.3 & 176 \\
Child's weight (female) & 2257 & 40.98 & 10.42 & 17.9 & 101.9 \\
Child's weight (male) & 2186 & 39.94 & 10.32 & 21.4 & 98.8 \\
High Blood Pressure & 4440 & 0.12 & 0.32 & 0 & 1 \\
Asthma & 4426 & 0.28 & 0.45 & 0 & 1 \\
Diabetes & 4421 & 0.00 & 0.06 & 0 & 1 \\
Number Hospitalisations & 4418 & 0.87 & 2.85 & 0 & 55 \\
Child's Psychological Score SDQ & 4361 & 14.17 & 7.95 & 0 & 46 \\
Conduct & 4405 & 2.50 & 2.32 & 0 & 10 \\
Hyper-active & 4408 & 4.33 & 3.09 & 0 & 10 \\
Emotions & 4404 & 4.20 & 2.71 & 0 & 10 \\
Peer & 4412 & 2.11 & 1.96 & 0 & 10 \\
Pro-social & 4419 & 8.95 & 1.63 & 0 & 10 \\
Relationship with mother & 4339 & 4.43 & 0.91 & 1 & 5 \\
Relationship with father & 4279 & 4.10 & 1.19 & 1 & 5 \\
Relationship between parents & 4266 & 3.82 & 1.33 & 1 & 5 \\
How often child reads p.w. & 4442 & 2.38 & 2.49 & 0 & 7 \\
Physical punishments (0-3) & 4335 & 0.63 & 0.87 & 0 & 3 \\
\hline \hline
\end{tabular}

Table 1.4 below depicts variables measured when our cohort members were on average 18 years old. We can see that primary education completion rate is $70 \%$ while secondary education completion stands at $30 \%$ of our sample. We must however warn the reader that at age 18 many youngsters are still on course to completing secondary education. This is shown by the fact $54 \%$ of our sample report to be currently studying while only $13 \%$ are studying at a post-secondary institution. This is also the reason we should show caution when looking at the percentage of those attending college, this number is still expected to increase as our cohort members became older. Table 3 also displays variables on health such as prevalence of asthma, diabetes and high

${ }^{9} \mathrm{~A}$ guide on this questionnaire is available at the World Health Organisations(27) 
Chapter 1. Family income and child development from gestation to age 18: evidence from Brazil

blood pressure. It shows that $6 \%$ of our sample was hospitalised at least once in the last year. Further, $10 \%$ is a teenage parent while $4 \%$ has ever been arrested or has ever been taken into juvenile institution.

Table 1.4: Descriptive Statistics at age 18

\begin{tabular}{lccccc}
\hline \hline & Descriptive Statistics at & 18 yrs & & & \\
\hline Variable & Obs & Mean & Std.Dev & Min & Max \\
\hline Household income 2011 R $\$$ & 4106 & 2134 & 3093 & 0 & 57300 \\
Schooling & 4104 & 8.62 & 2.30 & 0 & 12 \\
Completed Primary Education & 4104 & .71 & .45 & 0 & 1 \\
Completed Secondary Education & 4104 & .29 & .46 & 0 & 1 \\
Attends post-secondary Institution & 4104 & 0.13 & 0.34 & 0 & 1 \\
Has at least one child & 3880 & 0.10 & 0.30 & 0 & 1 \\
Has ever been arrested or institutionalised & 3879 & 0.04 & 0.21 & 0 & 1 \\
Paid work in the last year & 4103 & 0.69 & .46 & 0 & 1 \\
Health index & 3870 & 0.09 & 0.13 & 0 & 0.60 \\
Asthma & 4102 & 0.22 & 0.41 & 0 & 1 \\
Diabetes & 4100 & 0.04 & 0.19 & 0 & 1 \\
High blood pressure & 4102 & 0.09 & 0.29 & 0 & 1 \\
Hospitalised in last year & 4106 & 0.06 & 0.23 & 0 & 1 \\
\hline \hline
\end{tabular}

In chapter two, we use fluctuations in the average value real minimum wages during pregnancy and in the first year of life as an exogenous shock to household income. Before we delve into the results of this section we explain how we constructed this variable. First we collected the value of national minimum wage in Brazilian Reais for the period of January 1992 until December $1994,{ }^{10}$. The second step is to deflate the wages data using the monthly Brazilian Consumer Price Index ${ }^{11}$ for the city of Porto Alegre, the capital of the State of Rio Grande do Sul. In this way we have the value of the minimum wage on a monthly basis for the period of 1992-94. The final step consists of generating a daily real national minimum wage, by simply dividing the monthly values by the numbers of days in each month. We choose to provide estimates by trimester of pregnancy as there exist bio-medical evidence on differential effects of adverse by trimester of pregnancy. Please see appendix for the distribution of the value real minimum wages in each trimester of pregnancy by date of birth.

We now turn to attrition analysis. We have 3,969 observations that belong to all three: our perinatal, our 11 years and our 18 years data waves, representing $76 \%$ of the original sample. In the appendix we run a conjunction of F-tests on mean differences of selected variables between the individuals that belong to all waves of data versus those who have left our sample in at least one year. From our attrition analysis we see that those with higher incomes and weaker health are more likely to have left the survey. We note that some

\footnotetext{
${ }^{10}$ Downloaded from the Brazilian Institute of Applied Economic Research IPEA

${ }^{11}$ We used the Brazilian Consumer Price Index Índice Nacional de Preços ao Consumidor downloaded from the Brazilian Institute of Applied Economic Research IPEA
} 
Chapter 1. Family income and child development from gestation to age 18: evidence from Brazil

attrition is expected as those with worse health are also more likely to have left the sample due to death. In the foetal origins hypothesis literature, the loss of observations due to death, know as culling, is considered a source attenuation bias, since those who have suffered with lowest levels of parental investment during gestation are also subject to higher early-life mortality rates. However worse health is associated with lower income levels and as above our attrition analysis points to those with higher incomes having left the cohort. Hence death is not the sole source of attrition. We cannot fully account for attrition, and this is a limitation of our study.

In the second chapter, the first step of our estimation is done using each variable at time ${ }^{12}$. This means that we use all the observations available for each variable at a time, instead of all observations that have the complete set of variables used in our analysis. This in turn reduces attrition bias especially for variables at birth for which we have the entire sample ${ }^{13}$.

Finally we note that all variables have been standardised using agespecific means and standard deviations ${ }^{14}$. To reduce the sensitivity to outliers and small sample sizes within age categories, we compute the age conditional means and standard deviations using a kernel-weighted local polynomial smoothing method, as in $(28,18)$.

\section{3 \\ Methodology}

\subsection{1}

Income and human capital outcomes: mechanisms

In this section we discuss some of the possible mechanisms behind the association between human capital outcomes in early adulthood and family income. Our article does not intend to determine mechanisms, but this section aids the interpretation of our results.

Economists emphasise the role of credit constraints. In the presence of perfect financial markets low-income families would be able to borrow against future earnings of their children, or their own, to ensure each child receives resources consistent with their innate abilities and family preferences throughout their life. However, when borrowing opportunities are restricted, investments in children and the choice of environment surrounding them is

\footnotetext{
${ }^{12}$ This estimation is also found in (20)

${ }^{13}$ Further, in chapter 1 We have tried to use Heckman sample selection techniques to correct for attrition bias. However, the attempt was fruitless. Our first stage was weak. Further, the probability of leaving the sample was found to not affect any of our explained variables. Hence we excluded this correction from our regression analysis of Chapter 1.

${ }^{14}$ Age in our sample is measured in months
} 
Chapter 1. Family income and child development from gestation to age 18: evidence from Brazil

limited by the level of current income of the family. It is also recognised that financial market imperfections may have intergenerational impacts through parental abilities, that is a child's development may depend not only on whether their parents are credit-constrained but if their grandparent's faced credit constraints. Parental abilities play an important role in shaping child abilities either through children inheriting these abilities or through parental ability enabling higher quality childhood environments and higher levels of parental investments. In this manner, as in (10) we arrive at three channels behind the association between human capital and family income, genetics, parental investments and quality of childhood environments. Although, all of these channels could arise as a result of credit constraints they do not exclusively arise because of them.

We shed some light on this discussion by depicting, in the appendix, a simple theoretical model of the relationship between income at different periods of a child's life-cycle and human capital outcomes in adulthood. Albeit simple, we see that under the model family income affects human capital if and only if we have credit constraints on child investments. The model which is a modified version ((15)), has some unrealistic assumptions. Namely perfectly altruistic parents and human capital at adulthood does not depend on parental human capital. If we relax these assumptions we allow for wider role of income in explaining human capital outcomes. The first is that genetics assume a role in the relationship between parental income and human capital. The second is that if parental income is correlated with parental altruism, we will see a relationship between in family income and human capital formation. However, even relaxing such assumption we may not fully cover all mechanisms behind the association of family income and adult success.

Other fields, as sociology and psychology have also researched the relationship between income and adult success. (29) distinguishes between two pathways: i) investments mediators a model where a child's success is determined by parental material and time investments ii) family stress mediators which uses variables reflecting feelings of economic strain, mother's emotional distress and warm and punitive parenting. The first pathway is in line with the economist's credit constrain view. However the second model represents a somewhat new perspective where family emotional distress due to economic hardship, which could be present even in the presence of perfect financial markets, affects parenting quality and in this way child's development.

Overall, although there are various possible mechanisms behind the correlation between family income and human capital credit constraints are likely to indeed have a prominent role. Family credit constraints potentially 
Chapter 1. Family income and child development from gestation to age 18: evidence from Brazil

affect the main channels discussed here: material investments and choice of child environment as well as parental emotional distress.

\subsection{2}

\section{Regression analysis}

Our methodology is simple, we use regression analysis to investigate the relationship between household income at birth, at late childhood, and at late adolescence and variables that reflect human capital at age 18 . We begin with measures of educational attainment. These are last grade completed, probability of entering a post-secondary institution and probability of secondaryschooling completion. We follow to analyse the probability of being a teenage parent and of having spent time in jail or a youth facility. We also add a measure of health, we construct an index health problems at age 18 which is created from dummies on the following health conditions: asthma, diabetes, high-blood pressure or having been admitted to hospital in the year before the interview.

In order to gain a deeper understanding of the relationship between income at different stages of childhood and human capital we also analyse intermediate outcomes, which are measured at age 11. Specifically we look at number of grade retentions and two sub-dimensions the Strengths and Difficulties Questionnaire. The external mental health variable which contains scores related to adolescents' attentional capabilities and ability to control his or her conduct. The internal mental health variable which reflects issues related to depression, difficulties in making friends and others. ${ }^{15}$. Specifically we estimate the following equation:

$$
H_{i}=\beta_{0}+\beta_{1} \ln y_{i, t}+\delta X_{i}+\epsilon_{i}
$$

Where $H_{i}$ is the outcome of interest measured either at age 18 or at age 11 and $y_{i, t}$ represents family income at the different time periods. The selection and grouping of control variables $y_{i, t}$ is based on the seminar model of Cunha, Heckman and Schennach (1). In the model child abilities -or skills- are shaped by a combination of previous stocks of ability, parental investments, parental abilities and family characteristics. We add blocks of control variables in the following manner: i) standard socio-economic controls ii) measurements of parental abilities iii) measurements of child's abilities iv) parental investments in the previous period.

\footnotetext{
${ }^{15}$ The appendix contains the results of each of the 5 dimension of SDQ which compose the externalising and internalising scores
} 
Chapter 1. Family income and child development from gestation to age 18: evidence from Brazil

Standard socio economic controls are the child's gender, the child's race, whether parent's live together or not, the mother's age, the child's age and the number of time the mother has been pregnant. The second block contains parental years of completed education, a normalised score of psychological problems for the mother, mother's weight and height, and a dummy on weather either parent has ever suffered from psychological problems. The child abilities component at age 11 consists of the five dimensions of the SDQ mental health normalised scores, the number of grade repetitions and difficulties at school, height-for-age and weight-for-age at age 11 and health at birth. Parental investments at age 11 are measured using the child's rating of the relationship with the father and the mother on 1-5 scale, the number of beatings the child's reported receiving in the six months before the interview and how often the child reads newspapers, books or magazines in an average week ${ }^{16}$. The Abilities at birth block is composed weight at birth height at birth, head circumference, abdominal circumference, thoracic circumference and Dubowitz gestation age score ${ }^{17}$. Parental investments at gestation are measured using number and index on the quality of pre-natal visits, month of first pre-natal visit and whether the mother smoked during pregnancy. Note that we do not have any direct controls for the child's cognitive ability in our population. However, as described our dataset is rich, and we have variables which are highly related to cognitive ability such number of repetitions at school, external and internal socio-emotional skills, and parental education. All family income variables are normalised, so comparison between coefficients found in our regressions is direct.

The idea behind this methodology is that the first two blocks control for family characteristics that are time invariant, such as family preferences, family composition and at large, parental abilities ${ }^{18}$. We then introduce the block containing child abilities inherited from the previous periods, which we expect would reduce the coefficients of past income by more than current family income. The final block, parental investments in previous period, should affect all family income variables. This is because although the variable is measured at age 11, or at birth, it also reflects a permanent component of parental investments. The introduction of all blocks should reduce the family income coefficients as our measurements largely reflect the three channels of through which income relates to child development: genetics, parental investments and quality of childhood environments (10).

\footnotetext{
${ }^{16}$ The first two variables were taken from confidential questionnaires.

${ }^{17}$ all anthropometric measures are normalised by gender

${ }^{18}$ (18) finds that an ECD programme was not able to change parental abilities and we reach the same conclusion in our later article A structural assessment of Chile Crece Contigo
} 
Chapter 1. Family income and child development from gestation to age 18: evidence from Brazil

However the significance of family income may not disappear all together due to omitted variable bias. Noticeably we do not control for current child abilities ${ }^{19}$, and we do not have any controls for the child's cognitive ability. It is also worth noting that our methodology implies a linear relationship between income and child development. From the literature on production function of abilities, $(1,18,19,20)$, we know that there are important non-linearities in this relationship, which also affects our estimates.

\section{4 \\ Results}

\subsection{1}

\section{Human capital outcomes at adulthood}

In this section we examine the effects of family income on variables that reflect human capital outcomes at age 18. Overall figure 1.1 shows that our measurements of educational attainment and the probability of having had a child by age 18 or before are affected by all our family income variables, and this results persists after the introduction of our wide range of controls. We observe that income at birth and at age 11 have higher coefficients in our first two specifications, however once we include parental abilities all coefficients become similar in magnitude. This points at the fact that family income during birth and childhood having a greater correlation with family characteristics and education, perhaps because these controls were all measured at those ages. For health index and the probability having been incarcerated by age 18 we see that only income at birth is significant. For the former the coefficient estimate is independent of specification while for latter the pattern is as described for our other variables.

We begin with completed years of education at age 18, first sub-figure of 1.1. We have our three measures of family income. We see that without any controls income at birth and at age eleven has a coefficient that is twice the coefficient of family income at age 18. As we add our controls for family characteristics and parental ability the relative importance of each of our income variables becomes closer: a on standard deviation increase in family income augments education by 1-2 months. Note that significance of family income persists even after the addition of an array of explanatory variables. We interpret this as evidence suggesting that educational attainment at age 18 is affected by credit constraints which are present from gestation to age 18

\footnotetext{
${ }^{19}$ Unfortunately, we do not have measures of ability at age 18 in our dataset. In order to keep our methodology consistent we also do not include ability at age 11 when analysing outcomes at age 11
} 
Chapter 1. Family income and child development from gestation to age 18: evidence from Brazil

Figure 1.1: Family income and human capital outcomes at age 18

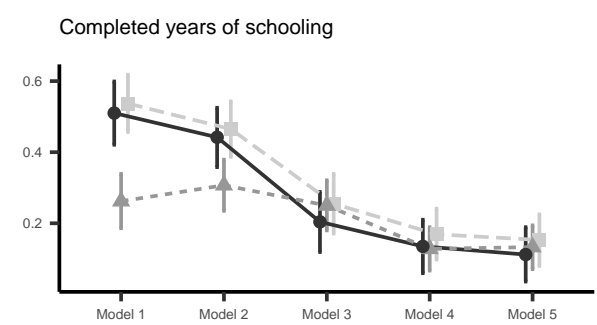

Probability of attending University

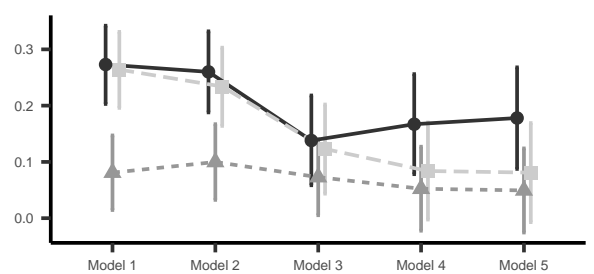

- Income age 11

Income age 11 Income age 18

Probability of completing Secondary School

Probability of having at least one child
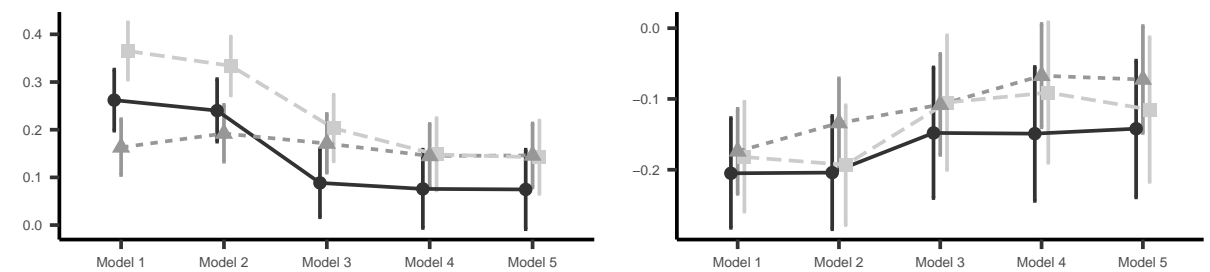

- Income age $11 \quad$ Income age 18 Income at birth

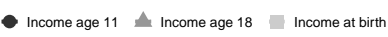

Probability of incarceration

Health problems index
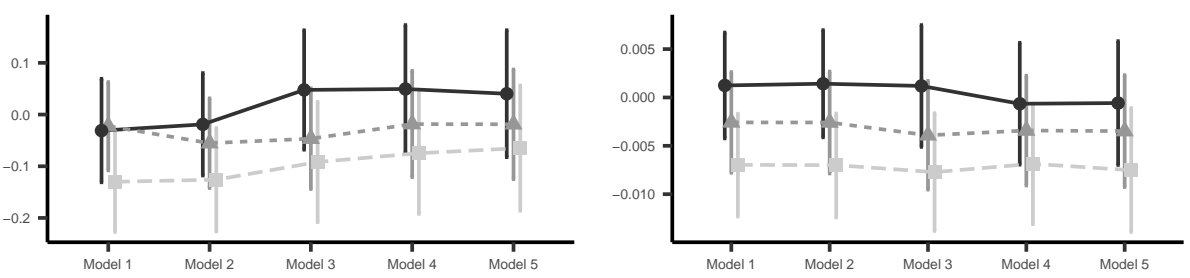

- Income age 11 Income age 18

- Income age $11 \quad$ Income age $18 \quad$ Income at birth

Model 1: no controls. Model 2: standard socio-economic controls. Model 3: model $2+$ measurements of parental abilities. Model 4: model $3+$ measurements of child's abilities. Model 5: model 4+ parental investments in the previous period.

The second figure of the first row of 1.1 looks at the probability of attending a Post-Secondary Institution at age $18^{20}$. Again, we begin with a picture of past levels of parental income having much higher coefficients when compared to current income. This pattern persists as we progress with the addition of our blocks of controls, at parental income at age 18 ceases to be significant. This is line with literature on borrowing constraints and University attendance which shows that current constraints explain only a small part of the observed variance in University attendance.

We observe that family income at birth has a higher correlation with Secondary-School completion, when compared to family income at age 11, which in turn has a higher correlation than family income at age 18. An increase in one standard deviation of family income at birth is associated with a 0.12

${ }^{20}$ In our classification of Post-Secondary Institution we have Universities, technical courses, and courses aimed a passing entrance exams to Universities Pré-Vestibular 
Chapter 1. Family income and child development from gestation to age 18: evidence from Brazil

points increase in the mean probability of having finished secondary school at age 18 , which is 0.29 . The same point estimate for income at late childhood is 0.9 while for income at age 18 we have a value of .06 . Including our full range of control variables family income at birth and current family income have similar coefficients, 0.04, while family income at age 11 has half of that value. The results suggest that family credit constraints affects the probability of completing secondary education. These constraints are most pervasive in gestation and childhood. We also note that easing constraints at age 18 would still impact secondary education completion at the correct age.

We analyse another human capital outcome which is having a child at age 18 or earlier. We see on the fourth sub-figure of that an increase in one standard deviation in family income in any of our three periods is associated with an approximately 0.03 reduction in the mean probability of having a child by age 18 , which is 0.10 . The significance of our three variables of family income remains after the inclusion of our blocks of controls. However, we observe higher impacts family income at age 11 and at birth when compared to current levels of family income. Again, we see this as suggestive evidence of the existence credit constraints impacting the probability of being a teenage parent, with highest impacts being felt at earlier years.

We proceed to look at the probability of having ever stayed at juvenile detention facility, or a prison by age 18 . we observe that only income at birth has a correlation with incarceration probability. If we increase family income at birth by one standard deviation the probability of have ever been arrested decreases by 0.01 points from a mean of 0.04 . This correlation however appears to work through family characteristics and parental abilities, as we control for those variables the effect recedes.

The final sub-figure depicts correlations between family income throughout the child's lifecycle and a health problems index at age 18. We observe that only family income at birth appears to explain the emergence of health problems at age 18. Further, this correlation remains strong after the addition of controls.

\section{4 .2 \\ Intermediate outcomes}

This subsection is dedicated to the analysis of outcomes at age 11. Overall we see that family income at birth and at age 11 are significant predictors of human capital at age 11 controls and that the estimated effects fall significantly after the inclusion of parental abilities.

The first intermediate outcome we analyse is years of completed educa- 
Chapter 1. Family income and child development from gestation to age 18: evidence from Brazil

Figure 1.2: Family income and human capital outcomes at age 11

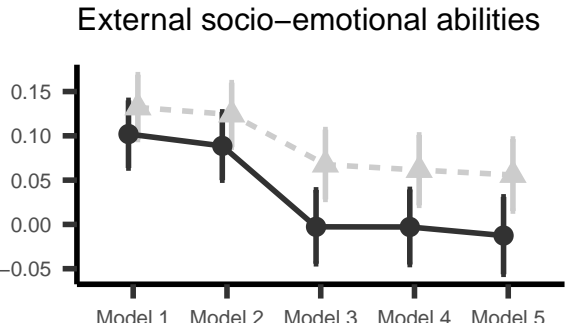

Income age $11 \ldots$ Income at birth

Completed years of schooling

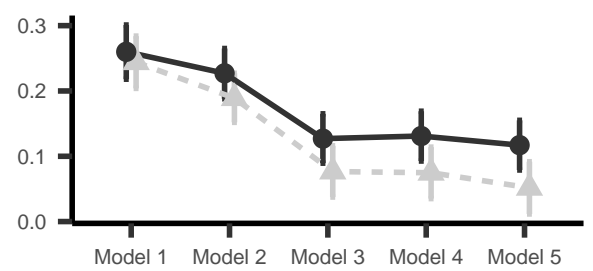

- Income age $11 \simeq$ Income at birth
Internal socio-emotional abilities

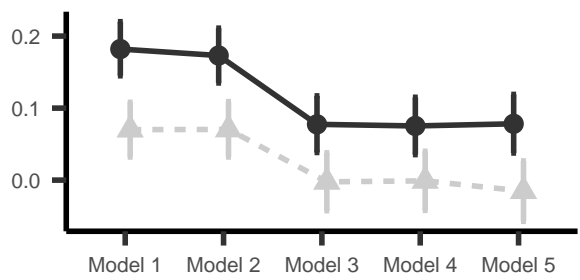

- Income age $11=$ Income at birth

Model 1: no controls. Model 2: standard socio-economic controls. Model 3: model $2+$ measurements of parental abilities. Model 4: model $3+$ measurements of child's abilities. Model 5: model $4+$ parental investments in the previous period.

tion at age 11. Both parental income at birth and current income positively affect years of completed education. Augmenting family incomes by one standard deviation from its mean level raises years by 3 months. As expected the introduction of our controls impacts earlier income more. However, both are significant predictors of educational attainment even with our range of controls.

The second sub figure of 1.2 shows that the correlation between family income at birth and externalising scores is higher then that of current family income. Further, the correlation between current income and externalising scores appears to work through parental abilities, as we see the significance of current income disappears once we control for parental abilities. Family income at birth continues to predict externalising scores even after we add blocks of control variables.

Interestingly, the picture for internalising scores is a mirrored reflection of externalising scores. Current family income begins with higher correlation when compared to income at birth and income at birth ceases to be significant once we control for parental abilities while current incomes continues to be 
Chapter 1. Family income and child development from gestation to age 18: evidence from Brazil

significant after the addition of all of our controls. We take this as evidence that internalising and externalising scores are in fact measuring different capabilities which react in an opposing manner family income at birth and current, age 11, family income.

\section{5}

\section{Conclusion}

We analyse the relationship between family income at different points of the child life-cycle and human capital outcomes using a rich panel dataset from a middle-income country, Brazil.

We find evidence consistent with of the existence of credit constraints throughout a child's life-cycle. Family income predicts number of years of education, probability of attending University, probability of finishing secondary education, probability of becoming a teenage parent, and overall health even after we control for family characteristics, parental abilities, child stock of abilities and parental investment. This persistence is surprising since we believe the principle channels behind this relationship would be covered by our controls. In line with literature on child development our results shows that these constraints are likely most binding at birth and childhood years, although constraints also likely to be present at adolescence. After turning our attention to human capital outcomes at age 11 we continue to observe strong effects of family income at different points of the child's life-cycle on total years of education and socio-emotional abilities. Again these effects remain after the introduction of our wide range of controls. We propose two alternative explanations for this finding. The first is that we still suffer from omitted variable bias even after our wide range of controls, noticeably we control only for past child abilities and we do not have controls for cognitive abilities. A second and non-rival explanation is that the association between income and human capital is indeed stronger in developing countries as supported by evidence from the USA of a stronger association between child and adult achievement amongst low-income families. Our findings thus support the need for more studies on the association between family and child and adult-success in middle and low income countries. 


\section{Human capital formation from gestation to age 18: evidence from Brazil}

\section{1 Introduction}

A human capital formation framework is the basis for understanding the origins of human inequality and for devising policies to reduce it(30). (31) delineates a multi-period model of human capital formation in childhood and adolescence where cognitive and socio-emotional skills are formed by parental investments, inherited levels of past skills and environmental characteristics. The model features 'self-productivity' higher levels of a skill in one period creates higher levels of that skill in future periods; 'cross-productivity' higher levels of a skill in one period creates higher levels of a different type of skill in future periods; 'dynamic complementarities' higher levels of skills in past periods make present investments in skills more productive. These features allows it to explain a large body of evidence in economics, psychology, neuroscience and education, $(32,33)$ summarises this literature. Namely it explains: the high rates of returns of early investments and the fact that late investments are more productive when preceded by early investment $(34,35,36,37)$; evidence on socio-emotional skills affecting cognitive skills(1); and the existence of critic and sensitive periods of child development(39). Moreover, the referred framework incorporates a dynamic relationship between genes and environment, where we no longer have a static -nature versus nurture- view of human capital formation but a complex interplay between genetic and environmental factors ${ }^{1}$

Contemporaneously, in health economics we have seen the consolidation of evidence that the environment we are exposed to during early development, from egg fertilisation to infancy, can have long term consequences for human capital. Prominent examples are the multitude of studies stemming from the natural experiment of the Dutch hunger winter of 1944-45, where the siege of Dutch cities by Nazi armies has been used to demonstrate the effects of food

${ }^{1}(40)$ offers an in depth explanation of this relationship which is accessible to a wide audience. 
deprivation during pregnancy on chronic disease, psychological health and labour market outcomes amongst others $(41,42)$. We also note $(43)$, which uses data from Norwegian twins to find that birth weight differences between twins predict height, IQ, earnings and education differences in adulthood. Heckman, in (30), states that it is a natural, and fruitful, step to join the health economics and human capital formation literature by adding health to the skills vector of (31) human capital formation framework. This proceeded to happen. $(20,19)$ use this framework to show that health is an important determinant of cognitive skills for children aged 1-15 in Peru and Ethiopia and for children aged 5-15 in India respectively. (44) uses a simplified linear version of the model and finds that health affects socio-emotional skills in children of 0-5 years of age in the U.K. Although the studies mentioned emphasise the role of gestation on long-term human capital, we have yet to see the inclusion of foetal investments in the human capital formation framework. Indeed (45), in their review of literature on long-term effects of in utero investments, the so-called foetal origins hypothesis, mentions the suitability of the human capital formation framework to consider such theory.

Our article contributes to both these literatures by joining them. We add foetal investments to the human capital formation framework of (31), and divide abilities into three dimensions health, internal and exteral socioemotional abilities. Joining the two strands of literature allows us to extend the current understanding of human capital formation to a wider dimension, health, and to a wider time-span which includes gestation. Specifically, we use the Pelotas 1993 birth cohort, which followed all children born in urban Pelotas, Brazil from birth to age 18, to estimate a production function of health and socio-emotional abilities. In our model abilities at birth are determined by investments in gestation, parental abilities and families characteristics. These abilities are inherited in subsequent periods and joined by, parental investments, parental abilities and family characteristics to determine subsequent levels of internal and external socio-emotional skills and health. Finally we relate these three dimensions of ability to human capital outcomes at age 18 .

Almond and Currie in (45) suggest priorities for future research on the foetal origins hypothesis. The first item is to identify long-term effects of less-extreme changes, those not related to natural disasters, in foetal environments. This, they say, would be extremely useful to guide policies on mother and child care. Our article contributes to this policy agenda. The year of 1993 was a period of hyperinflation in Brazil which meant that variations 
in the day of conception lead to variations in the real value of the National Minimum wage during the period of gestation ${ }^{2}$. We use these exogenous shifts in the real value of the minimum wage to identify the effects of changes in purchasing power of family income during gestation on in utero investments. We then use our structural framework allows us to document how changes in utero investments translate into different levels of human capital in adulthood.

Our findings suggest that investments in gestation and parental abilities are complements in producing newborn abilities. In fact the principal inputs of the production function of newborn abilities are gestational investment and maternal health. This is expected as maternal and foetal health are intrinsically related during gestation. We also find complementarities in the production function of health, socio-emotional and cognitive abilities in childhood as well as human capital at age 18. Taken together, our findings show that investments in gestation are more productive in terms of adult human capital when followed by high levels of parental investments during childhood. Thus policies aimed at increasing human capital at adulthood must consider investments from gestation trough to late childhood.

In terms of gestational investments, we find that changes in the real value of national minimum wage, especially in the first trimester of gestation, are linked to higher levels of investment in the baby to come, which impact levels of abilities found at birth. Birth abilities affect levels childhood health and cognition which in turn influence educational attainment at early adulthood. This points at high returns for policies aimed at increasing gestational investments such as raising the number of pre-natal visits and ensuring the first prenatal visit happens within the first trimester of pregnancy.

This chapter is organised as follows. We begin by explaining our modelling and estimation strategy. We proceed with results for production function of child abilities and human capital. We finalise with conclusions and next steps.

\section{2}

\section{Structural modelling and estimation ${ }^{3}$}

This section is divided into two sub-sections. The first section details the production function we wish to estimate. The second section is devoted to its

\footnotetext{
${ }^{2}(46)$ shows that the same variation in the first year of life affects child health and socioemotional skills at age 11, as well schooling at age 18 but only for low-educated mothers

${ }^{3}$ Based on the unpublished manuscript (2)
} 
Chapter 2. Human capital formation from gestation to age 18: evidence from Brazil

estimation, it explains the econometric challenges we face and our estimation procedure.

\subsection{1}

\section{The model}

Our model is based on the seminal article of Cunha, Heckman and Schennach(1). They develop a theoretical and empirical framework where a child's abilities depend on parental abilities, previous period abilities and parental investments through a Constant Elasticity of Substitution (CES) production technology.

The production function describes the formation of child abilities in two moments of time. The initial moment is the child's birth, which we denote by $t_{0}$. The second moment, which we denote by $t_{1}$, is 2004-5 when Pelotas cohort member were aged between 10-12 years. We assume a CES technology in the production of abilities. Child's ability at birth $\theta_{t_{0}}$ is a result of the combination of a vector of parental cognitive, socio-emotional skills and parental health $\boldsymbol{\Omega}=\left[\omega^{c}, \omega^{s}, \omega^{h}\right]$, gestational investment $i_{t_{0}}$, and a factor-neutral productivity parameter $A_{t_{0}}$. Note that child abilities at birth is single dimensional, this is because it is difficult to distinguish between abilities at birth. We define the production function of three types of abilities at age 11, given by $\theta_{t_{1}}^{k}$ for $k=c, s, h$ represents internal socio-emotional skills, external socio-emotional skills, and health respectively. The child's ability vector at age $11 \theta_{t_{1}}^{k}$ is a result of the combination of a vector of parental cognitive, socio-emotional skills and parental health $\Omega=\left[\omega^{c}, \omega^{s}, \omega^{h}\right]$, child's birth skills $\theta_{t_{0}}$, parental investment $i_{t_{1}}$, and a factor-neutral productivity parameter $A_{t_{1}}$. Our production functions of abilities at birth and of each of the three dimensions of child skills at age 11 are depicted below, the second in matrix notation.

$$
\theta_{t_{0}}=A_{t_{0}}\left[\gamma_{1, t_{0}}\left(i_{t_{0}}\right)^{\phi_{t_{0}}}+\gamma_{2, t_{0}}(\boldsymbol{\Omega})^{\phi_{t_{0}}}\right]^{\frac{1}{\phi_{t_{0}}}}
$$

where $\gamma_{1, t_{0}}, \gamma_{2, t_{0}}, \gamma_{3, t_{0}}, \phi^{t_{0}}$ are single parameters, and $A_{t_{0}}$ is given by the following expression which depends on a set of controls $\boldsymbol{X}$ and a random shocks $u_{t_{0}}$ :

$$
\begin{gathered}
A_{t_{0}}=\exp \left(\delta_{1, t_{0}}+\delta_{2, t_{0}} \boldsymbol{X}+u_{t_{0}}\right) \\
\theta_{t_{1}}^{k}=A_{t_{1}}^{k}\left[\gamma_{1, t_{1}}^{k}\left(i_{t_{1}}\right)^{\phi_{t_{1}}^{k}}+\gamma_{2, t_{1}}^{k}\left(\theta_{t_{0}}\right)^{\phi_{t_{1}}^{k}}+\gamma_{3, t_{1}}^{k}(\boldsymbol{\Omega})^{\phi_{t_{1}}^{k}}\right]^{\frac{1}{\phi_{t_{1}}}}
\end{gathered}
$$

where the production function parameters $\gamma_{1, t_{1}}^{k}, \gamma_{2, t_{1}}^{k}, \phi_{t_{1}}^{k}$ are vectors of the same length as $k$, while $\gamma_{3, t_{1}}^{k}$ is matrix of dimension $k x k$ and $A_{t_{1}}^{k}$ is given 
by the following equation:

$$
A_{t_{1}}^{k}=\exp \left(\delta_{1, t_{1}}^{k}+\delta_{2, t_{1}}^{k} \boldsymbol{X}+u_{t_{1}}^{k}\right)
$$

We follow to estimate how child abilities found at age 11 form human capital outcomes at age 18 . We continue to assume a CES production function but now we produce human capital using internal and external socio-emotional abilities and health as inputs. The function continues to control for family characteristics through a factor neutral productivity parameter. The human capital production function at age 18 is then:

$$
Q_{t_{2}}^{j}=A_{t_{2}}^{j}\left[\gamma_{1, t_{2}}^{j}\left(\theta_{t_{1}}^{c}\right)^{\phi_{t_{2}}^{j}}+\gamma_{2, t_{2}}^{j}\left(\theta_{t_{1}}^{s}\right)^{\phi_{t_{2}}^{j}}+\gamma_{3, t_{2}}^{j}\left(\theta_{t_{1}}^{h}\right)^{\phi_{t_{2}}^{j}}\right]^{\frac{1}{\phi_{t_{2}}}}
$$

again $\gamma_{1, t_{2}}^{j}, \gamma_{2, t_{2}}^{j}, \gamma_{3, t_{2}}^{j}, \phi_{t_{1}}^{k}$ are vectors of the same length as $j$, the number of human capital outcomes we have at age 18. $A_{t_{2}}^{j}$ is as above bar for the different superscripts and subscripts:

$$
A_{t_{2}}^{j}=\exp \left(\delta_{1, t_{2}}^{j}+\delta_{2, t_{2}}^{j} \boldsymbol{X}+u_{t_{2}}^{j}\right)
$$

The advantage of this functional form is that we do not have to assume a specific degree of substitutability between the inputs of our production function. The parameter $\boldsymbol{\Phi} \in(-\infty, 1]$ determines the elasticity of substitution, that is given by $\frac{1}{1-\boldsymbol{\Phi}}$ where $\boldsymbol{\Phi}=\left[\phi_{t_{0}}, \phi_{t_{1}}^{k}, \phi_{t_{1}}^{j}\right]$. The elasticity of substitution measures the sensitivity of the composition of the production function to changes in the relative productivity of each input. In the case of perfect substitutes $\phi=1$, we have that the relative productivity is constant for any combination of inputs, being even possible to produce using a single input. For $\phi \in(0,1)$ we have that a change in the relative productivity of inputs generates a greater than one-to-one change in the relative proportion of inputs. If $\phi=0$ the CES technology reduces to a Cobb-Douglas case, where the elasticity of substitution is one. For $\phi \in(-\infty, 0)$ we have that a change in the relative productivity of inputs generates a lesser than one-to-one change in the relative proportion of inputs. When $\phi$ approaches $-\infty$ we have a unique combination of inputs through which production increases, and any variation in that combination leads to infinite losses in relative marginal productivity. Finally, for any $\phi<1$ we have that the marginal productivity of each input depends on the level of other inputs, meaning we have some degree of complementarity between inputs. The lower $\phi$ the higher the complementarity between production function inputs.

We adopt a logarithm version of our model as in Attanasio et al (19). The equations to be estimated are thus: 


$$
\begin{aligned}
& \ln \theta_{t_{0}}=\frac{1}{\phi_{t_{0}}} \ln \left[\gamma_{1, t_{0}}\left(i_{t_{0}}\right)^{\phi_{t_{0}}}+\gamma_{2, t_{0}}(\boldsymbol{\Omega})^{\phi^{t_{1}}}\right]+\delta_{1, t_{1}}+\delta_{2, t_{1}} \boldsymbol{X}+u_{t_{1}} \\
& \ln \theta_{t_{1}}^{k}=\frac{1}{\phi_{t_{1}}^{k}} \ln \left[\gamma_{1, t_{1}}^{k}\left(i_{t_{1}}\right)^{\phi_{t_{1}}^{k}}+\gamma_{2, t_{1}}^{k}\left(\theta_{t_{0}}\right)^{\phi_{t_{1}}^{k}}+\gamma_{3, t_{1}}^{k}(\boldsymbol{\Omega})^{\phi_{t_{1}}^{k}}\right] \\
& +\delta_{1, t_{1}}^{k}+\delta_{2, t_{1}}^{k} \boldsymbol{X}+u_{t_{1}}^{k} \\
& \ln Q_{t_{2}}^{j}=\frac{1}{\phi_{t_{2}}^{j}} \ln \left[\gamma_{1, t_{2}}^{j}\left(\theta_{t_{1}}^{c}\right)^{\phi_{t_{2}}^{k}}+\gamma_{2, t_{2}}^{j}\left(\operatorname{theta}_{t_{1}}^{s}\right)^{\phi_{t_{1}}^{k}}+\gamma_{3, t_{2}}^{j}\left(\theta_{t_{1}}^{h}\right)^{\phi_{t_{2}}^{j}}\right] \\
& +\delta_{1, t_{2}}^{j}+\delta_{2, t_{2}}^{j} \boldsymbol{X}+u_{t_{2}}^{j}
\end{aligned}
$$

\subsection{2}

\section{Estimation}

The estimation of our non-linear production function is complex. We face two challenges: the variables of interest are non-observables, and parental investments may be endogenous. The variables of our function: child abilities, parental abilities and parental investments are latent traits. We do not observe them directly, but instead we have a variety of measures in our dataset that reflect these traits. Hence we need to develop a model that relates the measures in our data and our latent variables in a manner that permits a non-linear relationship between our latent variables.

The second problem with the estimation of our production function is that parental investments may suffer from endogeneity. This is because when parents make their investment decisions they may take into account random shocks to the child's ability. For example, if a child falls sick her parents may invest more in her to offset this negative shock, or act in a way to reinforce it.

In the next subsections we explain our estimation procedure, which deals with the non-observability and endogeneity problems, and follows Attanasio et. al.(19). Our estimation consists of three steps. In the first step, we estimate the distribution of our measurements. We then use the distribution of measurements to recover the distribution of latent factors. In the final step, using the distribution of latent factors we draw a synthetic dataset and apply non-linear least squares to estimate our non-linear production functions. 
Chapter 2. Human capital formation from gestation to age 18: evidence from Brazil

\subsubsection{1}

\section{A factor structure between measurements and latent variables}

The principle challenge with our estimation is the fact that our variables of interest are non-observable. Hence we need to model the relationship between our measurements and our latent factors. Denote our latent factors ability at birth, investment at birth, abilities at age 11, investment at age 11, parental abilities and controls by $\boldsymbol{\Psi}=\left[\theta_{t_{0}}, i_{t_{0}}, \theta_{t_{1}}^{k}, i_{t_{1}}, \boldsymbol{\Omega}, \mathbf{X}\right]$. We assume a factor structure between latent variables and measurements, where each measurement has a component associated with the latent factor and a component which is purely noise. The intuition behind factor models, such as ours, is that the common variance between our measurements is attributed to the latent factor they all reflect, while the remaining variance is the noise. The factor structure for each measurement is related to latent variables $\boldsymbol{\Psi}$ as follows:

$$
\begin{aligned}
M^{\theta_{t_{0}}} & =\beta^{\theta_{t_{0}}}+\lambda^{\theta_{t_{0}}} \ln \left(\theta_{t_{0}}\right)+\epsilon_{\theta_{t_{0}}} \\
M^{i_{t_{0}}} & =\beta^{i_{t_{0}}}+\lambda^{i_{t_{0}}} \ln \left(i_{t_{0}}\right)+\epsilon_{i_{t_{0}}} \\
M^{\boldsymbol{\Theta}_{t_{1}}} & =\beta^{\theta_{t_{1}}}+\lambda^{\theta_{t_{1}}} \ln \left(\boldsymbol{\Theta}_{t_{1}}\right)+\epsilon_{\boldsymbol{\Theta}_{t_{1}}} \\
M^{i_{t_{1}}} & =\beta^{i_{t_{1}}}+\lambda^{i_{t_{1}}} \ln \left(i_{t_{1}}\right)+\epsilon_{i_{t_{1}}} \\
M^{\boldsymbol{\Omega}} & =\beta^{\boldsymbol{\Omega}}+\lambda^{\boldsymbol{\Omega}} \ln (\boldsymbol{\Omega})+\epsilon_{\boldsymbol{\Omega}} \\
M^{\mathbf{X}} & =\mathbf{X}
\end{aligned}
$$

where $\quad M^{\theta_{t_{0}}}, M^{i_{t_{0}}}, M^{\boldsymbol{\Theta}_{t_{1}}}, M^{i_{t_{1}}}, M^{\Omega}, M^{\mathbf{X}}$ are vectors of measurements, $\beta^{\theta_{t_{0}}}, \beta^{i_{t_{0}}}, \beta^{\theta_{t_{1}}}, \beta^{i_{t_{1}}}, \beta^{\boldsymbol{\Omega}}$ are vectors of measurement means, $\lambda^{\theta_{t_{0}}}, \lambda^{i_{t_{0}}}, \lambda^{\theta_{t_{1}}}, \lambda^{i_{t_{1}}}, \lambda^{\Omega}$ are factor loadings and $\epsilon_{\theta_{t_{0}}}, \epsilon_{i_{t_{0}}}, \epsilon_{\boldsymbol{\Theta}_{t_{1}}}, \epsilon_{i_{t_{1}}}, \epsilon_{\boldsymbol{\Omega}}$ are idiosyncratic error terms. Notice that $\theta_{t_{0}}, i_{t_{0}}, \theta_{t_{1}}, i_{t_{1}}, \Omega$ are measured with error whereas the control variables, $\mathbf{X}$, are measured without error.

In order to identify the parameters of the measurement system, we assume that errors are orthogonal to latent variables and normalise our system by setting the factor loading coefficient of the first measurement of each latent variable to one, as the extant literature does. Further, we assume that errors are independent amongst themselves ${ }^{4}$.

At this point, we remind the reader that we wish to recover the distribution of latent factors. It is standard to assume normal distributions for all errors and measurements, which implies that latent factors also are mul-

${ }^{4}$ This assumption can be relaxed if we have more than two measurements per latent trait as shown in (1). However, data restrictions do not allow us explore this possibility. 
Chapter 2. Human capital formation from gestation to age 18: evidence from Brazil

tivariate normally distributed. Multivariate normal distribution implies that any linear combination of its components, latent variables, is also normally distributed. This implies linear conditional means of children abilities given other latent traits, ruling out a non-linear production function. In order to add enough flexibility we assume latent factors are drawn from a mixture of two normal distributions, as done by Attanasio et al $(19)^{5}$. We also assume that the errors of the equations above are normally distributed. We thus have:

$$
\epsilon \sim N\left(0, \Sigma^{\epsilon}\right)
$$

$$
f \ln \Psi=\tau f^{1} \ln \Psi+(1-\tau) f^{2}(\ln \Psi)
$$

where $f^{1}$ and $f^{2}$ are multivariate normal distribution and $\tau$ represents the weight of each distribution.

Given the above equations and our measurements to latent factor structure we can derive the following formula for our distribution of measurements:

$$
f(\tilde{m})=\tau \int g(\Lambda \ln \Psi-\tilde{m}) f^{1}(\ln \Psi) d \ln \Psi+(1-\tau) \int g(\Lambda \ln \Psi-\tilde{m}) f^{2}(\ln \Psi) \ln \Psi
$$

where $\mathrm{g}($.$) is \epsilon \sim N\left(0, \Sigma^{\epsilon}\right), f^{1}(\ln \Theta)=N\left(\mu^{1}, \Sigma^{1}\right), f^{2}(\ln \Theta)=N\left(\mu^{2}, \Sigma^{2}\right)$

\subsection{3}

\section{Endogeneity of parental investment in our production function}

Endogeneity of parental investments results in the error term of production function no longer being independent from parental investment, that is we have $E\left(u_{t_{0}} \mid \boldsymbol{\Omega}, i_{t_{0}}, \boldsymbol{X}\right) \neq 0, E\left(u_{t_{1}} \mid \theta_{t_{0}}, \boldsymbol{\Omega}, i_{t_{1}}, \boldsymbol{X}\right) \neq 0$. We solve this problem with the introduction of a control function for investment. We assume that the conditional expectation of the error term in equations (2-1,3-1), is linear on an endogeneity component $v_{t_{0}}, v_{t_{1}}$, and a true random error ${ }^{6}$. Hence, we have $E\left(u_{t_{0}} \mid \boldsymbol{\Omega}, i_{t_{0}}, \boldsymbol{X}\right)=E\left(u_{t_{0}} \mid v_{t_{0}}\right)=\rho v_{t_{0}}, E\left(u_{t_{1}} \mid \theta_{t_{0}}, \boldsymbol{\Omega}, i_{t_{1}}, \boldsymbol{X}\right)=E\left(u_{t_{1}} \mid v_{t_{1}}\right)=\rho v_{t_{1}}$, and the errors of the production function for time $t_{0}$ and $t_{1}$ becomes:

$$
u_{t_{0}}=\rho_{t_{0}} v_{t_{0}}+\zeta_{t_{0}}
$$

\footnotetext{
${ }^{5}$ Attanasio et al (2015) test mixed normal distributions with more than two components but revert to the two component normal mixture. The gain from adding mixtures is small when compared to the computational burden of such choices

${ }^{6}$ We also assume that both errors, $u_{t_{1}}$ and $v_{t_{1}}$, are jointly independent of the state variables $\theta_{t_{0}}, \boldsymbol{\Omega}, \boldsymbol{X}_{t_{1}}$, and that the parental investment has a one-to-one function with the endogenous error term, as in (47)
} 


$$
u_{t_{1}}=\rho_{t_{1}} v_{t_{1}}+\zeta_{t_{1}}
$$

We proceed to estimate the endogeneity components $v_{t_{0}}, v_{t_{1}}$, by constructing an equation with the determinants of our endogenous variable, investment. We assume the equation on the determinants of investments in time $t_{0}$ and $t_{1}$ are follows:

$$
\ln i_{t_{0}}=\alpha_{1, t_{0}}+\alpha_{2, t_{0}} \Omega+\alpha_{3, t_{0}} \boldsymbol{X}+\alpha_{4, t_{0}} \ln q_{t_{0}}+v_{t_{0}}
$$

$$
\ln i_{t_{1}}=\alpha_{1, t_{1}}+\alpha_{2, t_{1}} \ln \theta_{0}+\alpha_{3, t_{1}} \boldsymbol{\Omega}+\alpha_{4, t_{1}} \boldsymbol{X}+\alpha_{5, t_{1}} \ln q_{t_{1}}+v_{t_{1}}
$$

where, as standard, we assume that $E\left(v_{t_{0}} \mid \ln \boldsymbol{\Omega}, \boldsymbol{X}, \ln q_{t_{0}}\right)=0$ $E\left(v_{t_{1}} \mid \ln \theta_{t_{0}}, \ln \Omega, \boldsymbol{X}, \ln q_{t_{1}}\right)=0$. The investment equation contains all variables of the production function in addition to an instrument, $\ln q_{t_{0}}, \ln q_{t_{1}}$ for birth and age 11 time periods respectively. Our identification rests on finding a variable that affects ability only via parental investments. A natural candidate for our instruments are prices or income shocks. They are likely to affect investment through the family budget constraint, but not the production function directly.

Once we secure our identification, we use the investment equation to obtain an estimate of $\hat{v}_{t_{o}}$ and $\hat{v}_{t_{1}}$. This estimated error terms becomes an additional variable in our production functions, a variable that controls for the endogeneity of investment in time $t_{0}$ and $t_{1}$ respectively.

\subsubsection{1}

\section{Estimation Procedure}

We have now established our complete estimation approach. For clarity we detail each step of our estimation procedure.

In the first step, we estimate the distribution of demeaned measurements. We assume $f(\tilde{m})$ is a mixture of normal distributions given by the equation (??). We use an Expectation Maximisation algorithm ${ }^{7}$ to estimate the means and variance-covariance matrices of $f(\tilde{m}): \tilde{\mu}^{1}, \tilde{\Sigma}^{1}, \tilde{\mu}^{2}, \tilde{\Sigma}^{2}, \tilde{\tau}$.

${ }^{7}$ This method has been widely utilised for estimating mixture of normals, as described in (48). This method consists of two steps. First, the expectation step computes the probability that each observation belongs to one of the normal distributions given a set of parameters. Then, given these probabilities, we find parameters which maximize the log-likelihood function. These two steps are repeated until convergence. We also note that our initial set of parameters is found using a K-means distribution. 
In the next step, we estimate the distribution of latent variables $f(\ln \Psi)$, which is defined by the means and covariance-variance matrices of each mixture component, given by $\mu^{1}, \Sigma^{1}, \mu^{2}, \Sigma^{2}, \tau$, factor loadings matrix $\Lambda$ and the covariance matrix of the distribution of errors $\Sigma^{\epsilon}$.

The parameters of the latent variables are given by the minimum distance between the right-hand side of the equation and the parameters of the distribution of measurements, obtained in the earlier step, in the left-hand side of the system below ${ }^{8}$.

$$
\begin{gathered}
\tau=E[\tilde{\tau}] \\
\Lambda \mu^{1}=E\left[\tilde{\mu}^{1}\right] \\
\Lambda \mu^{2}=E\left[\tilde{\mu}^{2}\right] \\
\Lambda^{\prime} \Sigma^{1} \Lambda+\Sigma^{\epsilon}=E\left[\tilde{\Sigma}^{1}\right] \\
\Lambda^{\prime} \Sigma^{2} \Lambda+\Sigma^{\epsilon}=E\left[\tilde{\Sigma}^{2}\right]
\end{gathered}
$$

The final step consists of using $f(\ln \Psi)$ to draw a synthetic dataset of latent factors and estimate our production, equations (2-1,3-1), as if the latent variables were observable. Specifically we use OLS to estimate the determinants of investment, equation $(2.2 .3,3.4 .3)$, and construct $\hat{v}_{t_{0}}$ and $\hat{v}_{t_{1}}$. Then we apply non-linear least squares with the addition of the endogeneity controls and estimate parameters of our production function.

The standard errors are obtained by a bootstrap procedure. We report confidence intervals for all our estimates. In this way, we do not need to assume a standard distribution to compute p-values for our estimates.

\section{3}

Results

\subsection{1}

\section{System of measurements and latent variables}

We begin by showing the measurements we chose for each of our latent variables, and their information to noise ratios or communality percentages. Our selection of measurements was guided by the still small literature on nonlinear production function of abilities $(1,19,18,20)$ and the availability of

${ }^{8}$ The only conceptual difference between our estimation and (19) is that they compute the covariance matrix between latent traits and control by equating it to the covariance matrix between the measurement of the latent trait which had its weight normalised to one and the controls. We on the other hand, minimise the distance between the covariance matrix of latent traits and controls and the covariance matrices of all measurements and controls. Our estimation is computationally more demanding but more general. 
measurement in our dataset. We note that the E.M algorithm often converges to a degenerate distribution or estimates became very imprecise with the use of dummy variables or variables with small variances (48). Hence we have avoided the use of discrete variables in our analysis unless those proved to be very informative. The distribution of each latent trait is depicted in the appendix.

When interpreting the results we remind the reader that latent traits are extracted from the common variance between each of its measurements, while the remaining variance is set aside and considered noise. Intuitively, consider interpreting the result of parental health, which is composed of mother's height and weight, it is common to think that this is not good measurements as weight is often negatively related to overall health in adults. However, consider how much of variation of weight is associated with the variation of height, the common variation is attributed to health, and the variation of weight that goes beyond height is excluded. This in turn appears plausible.

Table 2.1 shows our measurements of child's ability at birth. Our most informative variable is weight at birth which has over $80 \%$ communality with other variables, the same is true for thoracic circumference. We then have head circumference, abdominal circumference and length at birth which are all over $50 \%$ informative. The Dubowitz score which measures newborn neuromuscular and physical maturity has an information to noise ratio of $30 \%$ while the Apgaar score at one minute appears to be purely noise. Note that we have a wide range of measurements for this latent trait and our variables have higher levels of information than existing articles. However (1) divides their variables at birth between cognitive abilities formed of height and weigh at birth and motor-social development at birth, and socio-emotional abilities as friendliness at birth and birth difficulty. As we have mostly health measures and only two test scores, of which is one purely noise, we have opted for a single dimensional latent variable representing abilities at birth. Our gestation investment variable, which is a novelty in the literature is composed of 5 measurements. The most informative of them are the number of pre-natal visits and the month of the first pre-natal visit at ratios just below $50 \%$ and $35 \%$ respectively. Our variable on whether or not the mother smoked during gestation shows a communality of $10 \%$ while the quality of prenatal visits has $6 \%$ communality. The gestation weight gain variable measured as a distance from medical recommendations given the mother's BMI before pregnancy is extremely noisy ${ }^{9}$

\footnotetext{
${ }^{9}$ We have attempted to use the question on alcohol use and other dummies on pre-natal investments but the EM estimation converged to a degenerate distribution.
} 
Table 2.1: Signal percentage of measurements- latent variables at birth

\begin{tabular}{ccc}
\hline \hline & Measures & signal (\%) \\
\hline Abilities & Dubowitz gestational age score & 0.297 \\
at birth & Lenght at birth & 0.544 \\
& Head circumference at birth & 0.646 \\
& Thoracic circumference at birth & 0.805 \\
& Abdominal circumference at birth & 0.574 \\
Parental & Aapgar score 1 min & 0.013 \\
investment & Weight at birth & 0.810 \\
& Month of first prenatal visit & 0.342 \\
& Quality index of prenatal visits & 0.056 \\
& Smoked during pregnancy & 0.097 \\
& Gestation & 0.012 \\
& Neight gain distance from recommended & 0.489 \\
\hline \hline
\end{tabular}

Parental cognitive abilities consists of two measurements, mother's and father's schooling in years, both are very informative with signal to noise ratios of $49 \%$ and $67 \%$ respectively. The literature also uses cognitive test scores of the mother for recuperating parental abilities, however we do have any such variable in our data. Parental socio-emotional ability is measured using the mother's SRQ-20 neuroticism score, a variable measuring the number of social activities the mother participates in a week and a variable on weather either parents report having ever suffered from psychological problems. We see that the SRQ score has communality of $53 \%$ followed by the dummy on parental psychological problems at $25 \%$ and mother's social activity at $6 \%$. Parental health is composed of mother's height and weight, which show a 34 and 47 percent of information each. The measurements used in the latter two latent traits are consistent with current literature.

Table 2.2: Signal percentage of measurements- parental latent variables

\begin{tabular}{ccc}
\hline \hline & Measures & signal $(\%)$ \\
\hline Parental & Mother's education & 0.486 \\
cognitive skills & Father's education & 0.673 \\
Parental & Mother's social activity p.w & 0.061 \\
socio-emotional skills & Mother or father ever had psychological problems & 0.249 \\
& Mother's psychological score & 0.530 \\
Parental & Mother's weight & 0.468 \\
health & Mother's height & 0.336 \\
\hline \hline
\end{tabular}

We now analyse our system of variables for when cohort members were around 11 years of age. Our greatest drawback is the lack of test scores which reflect cognitive abilities. We attempt to solve this by using other variables in our dataset. First we use the number of times the child has repeated a year 
at school $^{10}$ and a variable which asked the child to rate from 1-4 the level of difficulties they felt at school. We have also separated the SDQ mental health score into internalising and externalising components. As described earlier externalising scores have been linked by psychology and neuroscience to executive functioning, which is defined as a cognitive process. The two dimensions of internalising scores, emotional problems and peer relations, are joined by the dimension of pro-social attitudes to form our internal socioemotional latent variable.

In table 2.3 we see that the variable relating to conduct is the most informative at $43 \%$ communality, followed by attentional and hyperactivity problems at $31 \%$. Our computed probability of repeating is around $25 \%$ informative while the same number for school difficulties rank is one tenth. In terms of internal socio-emotional abilities we have pro-social behaviour and emotional problems with $40 \%$ communality while peer problems score displays half of that ratio. In terms of health we have used the usual weight for age and height for age scores. Both variables are very informative and have a high level of common correlation, the information ratio for the former is over $80 \%$ and the latter in nearly $60 \%$. The chosen variables for parental investments are variables measuring the relationship between their father, their mother and between the parents. We have also included the number of times the child received beatings in the last six months and the number of number of books or magazines the child read in the last week. The literature tended to use either variables on the frequency of activities between child and parents, or amount spent on goods for the child ${ }^{11}$ We see the child's rating of the relationship with the father and the mother show similar ratios of information at over $50 \%$, while the relationship between parents has a lower coefficient at 30\%. The number of beatings and number of magazines read have a communality with our other investment variables of 9 and 4 percent respectively.

\subsection{2}

\section{Production function of child abilities}

We can move to the estimation of the production functions. The first step in the estimation is to obtain $\hat{v}$ through modelling the determinants of

\footnotetext{
${ }^{10}$ As described above our EM estimation does not comport discrete variables well. This was the case when we used the number of grade repetitions directly. We have then made this variable continuous by using the predicted probability of having repeated a year. We use a poisson model where the explanatory variables are father and mother's education, the school the child attends, the number of books or magazines per week the child reads and the current level of family income.

${ }^{11}$ We have attempted to use variables on activities outside school, hours of TV per week, but these were purely noise and these have again resulted in imprecise estimations.
} 
Chapter 2. Human capital formation from gestation to age 18: evidence from Brazil

Table 2.3: Signal percentage of measurement of latent variables at age 11

\begin{tabular}{ccc}
\hline \hline & Measures & signal (\%) \\
\hline Cognitive & Hyperactivity score (-) & 0.311 \\
abilities & Conduct score (-) & 0.429 \\
& Difficulties at school (1-4) & 0.105 \\
& Probability of repeating a year & 0.257 \\
Socio-emotional & Emotional problems score (-) & 0.404 \\
abilities & Peer problems score (-) & 0.214 \\
& Prosocial behaviour score & 0.400 \\
Health & Weight for age & 0.585 \\
& Height for age & 0.829 \\
Parental & Relationship with father (1-5) & 0.518 \\
investment & Relationship with mother (1-5) & 0.520 \\
& Number of beatings in 6m & 0.088 \\
& Relationship between parents (1-5) & 0.297 \\
& Number of book or magazines read p.w & 0.038 \\
\hline \hline
\end{tabular}

investment. As explained in the model section we need a variable that affects the production function only through its effect on parental investments. We use variables measuring changes in the average value of national minimum wage during the first, second and third trimester of gestation. We argue the shock exogenous for it depends on 3 variables largely outside household's control: i) the date of birth of the child ii) the rate of inflation during pregnancy and first year of life iii) dates of increase in the nominal value of the Brazilian National Minimum wage.

In 2004, when our cohort members were between 10-12 years of age Brazil was no longer suffering from a hyper-inflation episode precluding the use of similar variable. However, a good candidate are the fluctuations family income from its permanent component, as shown in the equation below. We argue that given extended range of control of parental attributes such abilities, health, age and family composition these income shocks are truly unexpected and exogenous. We compute our fluctuation in income using the equation below, where we recuperate the predicted value for household income at age 11 and subtract it from the actual household income at age 11. As a second instrument we use weather or not the head of household was classified as unemployed. Again we see this variables as unexpected shock.

$$
y_{1}=\rho y_{0}+u_{1}
$$

Table 2.4 contains the determinants gestational and age 11 parental investments. For gestational investments we see that the value of the National Minimum Wage in gestation during the first trimester of pregnancy significantly predicts gestational investments. The effect is however modest: a one 1 
Table 2.4: Equations on the determinants of investment

\begin{tabular}{|c|c|c|}
\hline & $\begin{array}{c}\text { Gestational } \\
\text { investment } \\
(1) \\
\end{array}$ & $\begin{array}{c}\text { Age } 11 \\
\text { investment } \\
(2)\end{array}$ \\
\hline Real National minimum wage 1st trimester & $\begin{array}{c}0.023 \\
(0.001,0.052)\end{array}$ & \\
\hline Real National minimum wage 2 nd trimester & $\begin{array}{c}-0.001 \\
(-0.016,0.042)\end{array}$ & \\
\hline Real National minimum wage 3rd trimester & $\begin{array}{c}0.021 \\
(-0.011,0.039)\end{array}$ & \\
\hline Real income shock age 11 & & $\begin{array}{c}0.008 \\
(-0.008,0.016)\end{array}$ \\
\hline Unemployed head of household & & $\begin{array}{c}-0.022 \\
(-0.029,-0.010)\end{array}$ \\
\hline Ability at birth & & $\begin{array}{c}0.003 \\
(-0.006,0.011)\end{array}$ \\
\hline Parental Cognition & $\begin{array}{c}0.394 \\
(0.357,0.517)\end{array}$ & $\begin{array}{c}0.031 \\
(0.017,0.050)\end{array}$ \\
\hline Parental Health & $\begin{array}{c}0.050 \\
(-0.017,0.111)\end{array}$ & $\begin{array}{c}0.001 \\
(-0.016,0.016)\end{array}$ \\
\hline Parental socio-emotional skills & $\begin{array}{c}-0.015 \\
(-0.087,0.029)\end{array}$ & $\begin{array}{c}0.060 \\
(0.037,0.086)\end{array}$ \\
\hline Child is male & $\begin{array}{c}0.009 \\
(-0.014,0.029)\end{array}$ & $\begin{array}{c}0.001 \\
(-0.005,0.006)\end{array}$ \\
\hline Number of pregnancies & $\begin{array}{c}-0.200 \\
(-0.226,-0.146)\end{array}$ & $\begin{array}{c}-0.011 \\
(-0.019,-0.003)\end{array}$ \\
\hline Child is not white & $\begin{array}{c}-0.070 \\
(-0.090,-0.029)\end{array}$ & $\begin{array}{c}-0.016 \\
(-0.027,-0.007)\end{array}$ \\
\hline Mother's Age & $\begin{array}{c}0.010 \\
(-0.035,0.031)\end{array}$ & $\begin{array}{c}0.013 \\
(0.004,0.022)\end{array}$ \\
\hline Constant & $\begin{array}{c}0.014 \\
(-0.011,0.033)\end{array}$ & $\begin{array}{c}0.0002 \\
(-0.004,0.013)\end{array}$ \\
\hline
\end{tabular}

$95 \%$ confidence intervals based on 100 bootstrap replications in parenthesis

standard deviation increase in the value of the average national minimum wage in the first trimester increases gestational investment by 0.02 standard deviations. In this function the only parental ability which significantly impacts gestational investment is cognition. Further larger families and non-white families are associated with lower levels of investments in pregnancy. For investments at age 11 parental cognition and socio-emotional skills show positive significant coefficients. Again the number of previous pregnancies, proxying the number of siblings, and race are negatively related to parental investments. For both ages we do not observe evidence on male bias. We note that both of our exogenous variables have the expected effect, with unemployment negatively affecting investments and positive fluctuations in income increasing investment. The latter however is not significant investment determinant at the $5 \%$ level

Table 2.5 offers our CES production functions of abilities at birth and cognitive, socio-emotional abilities and health at age 11 . We begin by analysing 
Table 2.5: CES Production function of children's abilities

\begin{tabular}{|c|c|c|c|c|}
\hline & $\begin{array}{c}\text { Ability at birth } \\
\text { (1) }\end{array}$ & $\begin{array}{c}\text { Cognition } \\
(2) \\
\end{array}$ & $\begin{array}{c}\text { Socio-emotional } \\
(3)\end{array}$ & $\begin{array}{c}\text { Health } \\
(4)\end{array}$ \\
\hline Parental investment & $\begin{array}{c}0.576 \\
(0.407,0.744)\end{array}$ & $\begin{array}{c}0.376 \\
(0.161,0.499)\end{array}$ & $\begin{array}{c}0.767 \\
(0.662,0.934)\end{array}$ & $\begin{array}{c}0.170 \\
(0.068,0.254)\end{array}$ \\
\hline Parental Cognition & $\begin{array}{c}-0.173 \\
(-0.273,-0.076)\end{array}$ & $\begin{array}{c}0.193 \\
(0.127,0.410)\end{array}$ & $\begin{array}{c}0.022 \\
(-0.017,0.060)\end{array}$ & $\begin{array}{c}0.092 \\
(0.050,0.154)\end{array}$ \\
\hline Parental socio-emotional skills & $\begin{array}{c}0.066 \\
(0.013,0.150)\end{array}$ & $\begin{array}{c}0.381 \\
(0.316,0.481)\end{array}$ & $\begin{array}{c}0.200 \\
(0.077,0.273)\end{array}$ & $\begin{array}{c}0.073 \\
(0.030,0.148)\end{array}$ \\
\hline Parental health & $\begin{array}{c}0.530 \\
(0.437,0.596)\end{array}$ & $\begin{array}{c}0.033 \\
(-0.067,0.054)\end{array}$ & $\begin{array}{c}0.012 \\
(-0.023,0.037)\end{array}$ & $\begin{array}{c}0.587 \\
(0.545,0.706)\end{array}$ \\
\hline Abilities at birth & & $\begin{array}{c}0.017 \\
(0.004,0.047)\end{array}$ & $\begin{array}{c}-0.002 \\
(-0.012,0.016)\end{array}$ & $\begin{array}{c}0.078 \\
(0.036,0.116)\end{array}$ \\
\hline Investment residual & $\begin{array}{c}-0.296 \\
(-0.464,-0.082)\end{array}$ & $\begin{array}{c}0.097 \\
(-0.075,0.509)\end{array}$ & $\begin{array}{c}-0.603 \\
(-0.865,-0.372)\end{array}$ & $\begin{array}{c}0.177 \\
(-0.077,0.334)\end{array}$ \\
\hline CES coefficient & $\begin{array}{c}-0.098 \\
(-0.230,0.027)\end{array}$ & $\begin{array}{c}-0.058 \\
(-0.135,-0.015)\end{array}$ & $\begin{array}{c}-0.049 \\
(-0.132,0.059)\end{array}$ & $\begin{array}{c}-0.072 \\
(-0.233,0.035)\end{array}$ \\
\hline Controls & Yes & Yes & Yes & Yes \\
\hline
\end{tabular}

$95 \%$ confidence intervals based on 100 bootstrap replications in parenthesis

Controls are: child's gender, child's race, mother's age and mother number of previous pregnancies

general patterns in the production functions. First we have CES coefficients that vary between $\boldsymbol{\Phi} \in(-\infty, 0]$ which means that the inputs of each the ability function are complements. Indeed, we find that the CES production function often reduces to a Cobb-Douglas case, where the elasticity of substitution between inputs is one. This is in line with existing literature. Secondly, the share of parental investment is positive and significant in all cases. This has important policy implications as parental investments are not fixed in time and respond to policy changes. Examples of policy evaluations which use the same human capital framework are (18) and the final chapter of this thesis, both find that policies in early childhood are effective in changing parental investments. Thirdly, investment residuals are significant and negative for abilities at birth and socio-emotional abilities and not significant for cognition and health. This again is consistent throughout literature: in $(19, ?)$ the investment residual coefficient of health is not distinguishable from zero in Ethiopia, Peru and India for most ages. The same coefficient for cognition is mostly negative but for some age brackets they also find non-significant effects in Peru and India. We interpret this as evidence that parents compensate shocks to the children's skills at birth and socio-emotional skills.

The first column of table 2.5 shows that newborn abilities at birth are most responsive to parental investments. This points at high returns for policies aimed at increasing gestational investments such as raising the number of pre-natal visits and ensuring the first prenatal visit happens within the first trimester of pregnancy. Another variable that has strong and significant impact on newborn abilities is parental health. This is expected as maternal health forms an intrinsic part foetal development during gestation. We also see that parental non-cognitive abilities show a positive and significant coefficient, this is line with foetal origins hypothesis, where maternal mental distress affects newborn well-being. The coefficient on parental cognitive abilities is negative 
and significant. This is contrary to expectations but not unique in literature, in (?) finds the same significant negative relationship between health at age 5-the youngest age- and parental cognition in Ethiopia. Further, in the final chapter of this thesis, we find the same significant negative relationship between child cognition at age 18-23 months and parental cognition in Chile. We note that when we exclude the component controlling for the endogeneity of parental investment this result disappears ${ }^{12}$. Finally, the CES coefficient is negative, however not different from zero at 5\% significance level, showing a CobbDouglas level of complementarity.

We turn to abilities at age 11 . We begin with our measure of cognition. As explained in the data section, we do not have a test measuring cognition directly, but a latent variable that reflects the child's schooling, the child's ability to focus and to control their behaviour. The production function shows that parental investments and parental socio-emotional skills have the highest input share at 0.38 , followed by parental cognition at 0.19 and abilities at birth 0.02 . All of which are significant coefficients at $5 \%$ level. In terms of cross productivity we see that abilities at birth produce cognitive skills. Note also that this is the only, function for which the CES is significantly different from zero, pointing at a higher level of complementarity than a Cobb-Douglas function.

Analysing socio-emotional abilities we see that only two inputs have shares which are significantly different from zero, parental investments and parental socio-emotional abilities. The former has a very high coefficient, pointing at high level of malleability of socio-emotional during early adolescence. Again, we have CES coefficient that shows the case of a Cobb-Douglas production function.

All inputs of the production function of child's health at age 11 are significant. The input with the highest share is parental health at near 0.60 , this also appears natural. Maternal and child height, both used to form each health latent traits, are very correlated. The same is true for maternal and child weight the other measurement variable used. Parental investments have a coefficient of 0.17 , followed by parental socio-emotional skills, parental cognition and the child's inherited abilities from birth. We note he cross productivity between abilities at birth and health at age 11. The health CES coefficient is not different to zero.

\footnotetext{
${ }^{12}$ We have tried to answer by controlling for type of delivery at birth. In our data ceaserean birth are correlated with parental abilities, and are also related to complications at birth as well as to gestational age at birth, however the introduction of the variable did not affect the results and brought instability to our EM estimation as explained in the model session. Thus we excluded this variable.
} 
Table 2.6: CES Production function of human capital outcomes

\begin{tabular}{lc}
\hline \hline & $\begin{array}{c}\text { Schooling at age 18 } \\
(1)\end{array}$ \\
\hline Cognitive skills & 0.913 \\
& $(0.684,1.129)$ \\
Socio-emotional skills & -0.113 \\
& $(-0.324,0.131)$ \\
Health & 0.200 \\
& $(0.159,0.228)$ \\
CES coefficient & 0.138 \\
& $(-0.060,0.270)$ \\
Controls & Yes \\
\hline \hline \\
95\% confidence intervals based on 100 bootstrap replications \\
in parenthesis \\
Controls are: child's gender, child's race, mother's age and \\
mother number of previous pregnancies
\end{tabular}

Finally we analyse human capital outcomes at age 18 . We see that cognitive and health skills positively affect completed years of schooling at age 18. However, the share of cognitive skills is much higher than of health, at .82 for the former and 0.16 for the later. The coefficient associated with socio-emotional skills is not different from zero in our case. This differs from (1), we believe this difference arises from the manner we measured cognitive and socio-emotional skills. Noticeably, our measure of cognitive skills contains years of school at 11, and measures of hyperactivity and behavioural problems which also contain a socio-emotional component. Again, human capital follows a Cobb-Douglas production with complementarity between child ability measurements.

The appendix contains two extra estimations of all production functions. First, we show the results of not including an investment endogeneity component. The endogenous CES are analogous to the above for health and cognitive abilities at age 11, for the endogeneity component is not significant. For abilities at birth and socio-emotional abilities the extra component increases the coefficient of investment while reducing the coefficient on parental abilities. This is evidence of the endogeneity of investment resulting in an overestimation of the effects of parental ability and an underestimation of the effects of parental investments. We have also included a CES function where we join all parental abilities. The nested CES function reduces to te former non-nested case for abilities at birth and socio-emotional abilities. This is because we cannot reject that both the inner CES parameter, measuring complementarity between parental skills, and the outer CES parameter, measuring complementarity between parental skills, parental investments and 
previous stock of abilities, are the same, they are both not different to zero. In the case of cognition we have a stronger complementarity between inputs of the production function than found in the CES function while the opposite is true for health. However the differences found are small and the conclusions reached when analysing the CES function continue to be true when analysing its nested version.

\section{4}

\section{Conclusion and next steps}

In this article we estimate a production function of abilities at birth and at age 11 . We find complementarities between the inputs of the production function: parental investments, parental abilities and stock of abilities inherited from previous periods. Consistent with extant literature our ability production functions generally follow a Cobb-Douglas technology. Gestation investments and parental health determine levels of child's abilities at birth. This is logical, during gestation maternal health is intrinsically related to foetal health. At childhood years we continue to see parental investment to have the largest shares amongst inputs. The exception is health for which the prominent factor is parental health. We have evidence of abilities at birth impacting cognition and health at age 11. In turn cognition and health at childhood impact educational attainment at age 18 . We also have complementarities between cognition, socio-emotional abilities and health in producing educational attainment at age 18 .

The policy implications of this article are encouraging. Parental investments are crucial to producing child abilities from gestation to age 11 . The complementarities found mean that investments in childhood are more productivity if preceded by high levels of gestational investment. In terms of prenatal policies we see that changes to real value family income during gestation, especially in the first trimester, raise levels of foetal investments, which impact abilities at birth. Birth abilities are linked to health and cognition in childhood years. Childhood levels of health an cognition in turn influence educational attainment at early adulthood. This existence of long-term returns for policies aimed at increasing gestational investments such as raising the number of pre-natal visits and ensuring the first prenatal visit happens within the first trimester of pregnancy. Our results support the foetal origins hypothesis.

There are many avenues for future work within this article, we highlight two. The first involves extending our dataset to gain a deeper understanding of our results. The article would greatly benefit from the inclusion of measures 
of child cognitive abilities. We intend to undertake this work by adding the mathematics and language results of the Prova Brasil to our dataset. Further, we could extend our analysis to ages between birth and age 11 by using the using surveys taken by subsets of the 1993 Pelotas Birth Cohort. This would clarify the mechanisms through which abilities at birth affect cognition and health at age 11. Finally, with access to wider range of variables at age 18 we could look at other human capital outcomes not necessarily educational attainment and estimate production functions at that age.

The second area of future work is quantifying our results through simulations on the effects of changes in gestational real income on human capital outcomes at adulthood. We can trace and measure the size of effects of these changes on prenatal investments, natal outcomes, abilities at childhood and finally adult human capital. Policy makers would then have an estimation of not only short-term but long-term rate of returns to foetal investments. To further enrich our analysis we could separate the effects found by family or child characteristics. This would allows to check for heterogeneous effects within our population and find child/mother pairs which are most responsive to, or alternatively, in need of prenatal investments. 


\section{A structural assessment of Chile Crece Contigo ${ }^{1}$}

\section{1}

\section{Introduction}

Extant literature established that well-target and well-designed Early Childhood Development (ECD) programmes affect children abilities ${ }^{2}$, with some impact lasting until adulthood. The prominent examples of such literature are: the Perry School Pre-school project implemented from 1962 to 1967 in the USA $(34,35)$, the Abecedarian project implemented between 1972 and 1977 also in USA (37), the INCAP nutritional programme which occurred in the mid 1960s in Guatemala (49), and finally the Jamaica home-visits project which happened between 1986-1987 (36). From a policy point of view however, the scaling up of such interventions remains a challenge (33). This article contributes to this literature by assessing the Chilean national early childhood policy Chile Crece Contigo.

The social protection system Chile Crece Contigo - ChCC hereinafter - is a comprehensive, intersectoral and multi-component policy aimed at reducing existing inequalities in the development of early childhood, from gestation until entry in the educational system (pre-school). The idea of the ChCC policy is to provide services, material resources and information to enhance the child's family environment and the parents participation in the child's care and education. Although some of its actions are universal, the policy focuses on families that use the public health system and who are classified as having bio-psycho-social vulnerabilities. The first point of contact between families and $\mathrm{ChCC}$ happens in the first pre-natal visit. During this visit personalised actions are devised according to the family's vulnerability level. From there on a wide range of services are offered to the family to offset such vulnerabilities with most of those happening during gestation and in the first year of the child's life.

A pillar of $\mathrm{ChCC}$ is the so called foetal origins hypothesis, the now consolidated idea that environment we are exposed to during early development,

${ }^{1}$ From the unpublished manuscript (2), written with Soraya Roman

${ }^{2} \mathrm{We}$, like (10) use the terms ability and skills interchangeably. 
from egg fertilisation to birth, can have short and long-term consequences on health, psycho-social behaviour and cognition (45). Examples of such literature are as follows. (60) reviews effects of maternal anxiety and stress during pregnancy on child outcomes to conclude that these lead to child conduct disorders such as ADHD, antisocial behaviour, schizophrenia. A number of contributions arise from studies of the natural experiment of the Dutch hunger winter of 1944-45, which demonstrates the effects of food deprivation during pregnancy on chronic disease, psychological health and labour market outcomes amongst others $(41,42)$.

Using data from 2010 and 2012 Longitudinal Early Childhood Survey of Chile (ELPI), we construct two cohorts of children, those who were conceived before and after the official date of ChCC expansion to the entire country. Thus our evaluation considers the comparison of two non-concurrent cohorts of children. In this manner we compare children exposed to $\mathrm{ChCC}$ from conception to those exposed at later point in their life. We choose this due to the focus of $\mathrm{ChCC}$ on prenatal behaviour and environment. We investigate whether different exposure to $\mathrm{ChCC}$ are associated with differences in parental investments and child abilities. Specifically, we estimate a production function of abilities for children conceived before and after the start of ChCC separately, as in (1). The latter allows us to i) view differences in distribution of abilities between the two groups children ii) map the mechanisms through which these changes occurred iii) check whether productivity of parental investments differs between groups. We estimate these cohort differences for two age groups: 18-23 months of age and 36-47 months of age.

We find that children who were exposed to ChCC since conception have higher levels of socio-emotional abilities when compared to children exposed at later stages. We however have inconclusive result for children's cognitive abilities. The higher levels of socio-emotional abilities are explained by both increases in parental investments and productivity of parental investments, with the latter explaining $40 \%-80 \%$ of the total effect. Our results suggest that $\mathrm{ChCC}$ had differential effects between age groups. For children of 18-23 months of age vulnerable populations appear to have felt the highest benefits. While for children of 36-47 months of age we find families at the top of ability distribution appear to have benefited most from the policy. Our results are consistent with prenatal behaviour and environment affecting the level and the productivity of parental investment during early childhood.

Our analyses builds on previous evaluations of the ChCC programme. Bedegral evaluates the short-term impact of a subsection of ChCC, the Biopsycho-social Development Support Programme -PADB in Spanish(50). In 
the same manner, the evaluation considers two non-concurrent (or historical) cohorts of children: those born before the the start and consolidation of the PADB program and those born after it but uses a different dataset to ours. The results show positive impacts on global development and in the socio-personal and adaptive development. Asesorías para el Desarrollo compares four groups according to two variables, the quality of implementation, given by the Key Performance Indicator by municipality and cohort(51). They find higher levels of child cognitive development for the treatment cohort only within districts defined as having high quality implementation. Our added value lays on using structural modelling to analyse the mechanisms behind ChCC.

This article is organised as follows. The next section, two, describes ChCC and its implementation in more detail. The third section delves into our data. The fourth section is dedicated to structural modelling. The fifth section shows our estimates of productions functions and distribution of parental investments and child's abilities. We follow with some simulation exercises. The final section concludes.

\section{2 \\ Chile Crece Contigo}

Chile Crece Contigo is Chile's social protection system for children. This national policy aims at reducing existing inequalities in the development of early childhood, from gestation until the entry to the educational system at its transitional level (pre-school).(54) The main idea of the policy is to improve child's cognitive and non-cognitive skills through actions that enhance the family environment, parenting skills and parental investment. Although some of ChCC services are available for the entire population ${ }^{3}$, the policy focuses on families that use the public health system and who are classified as having bio-psycho-social vulnerabilities.

The design and implementation of ChCC happened between 2007 and 2009. The central components of the policy are the Bio-psycho-social Development Support Programme (PADBP in Spanish) and the Basic Community Networks, which were designed until June 2007. The policy was implemented in 159 pilot districts on that date and expanded to the whole country in 2008 . The pilot districts implemented only the actions for pregnant women, attending only $19 \%$ of 2007 's live births, which represented $24 \%$ of live births in the public health system. The expansion of the policy in 2008 was rapid. In fact, all pregnancies, live births and children under 2 years old registered in the public

${ }^{3}$ Among these services are radio promotional campaigns related to early childhood development, a website and toll-free line for information and support on childcare 
Table 3.1: Coverage and expansion of Chile crece contigo

\begin{tabular}{|c|c|c|c|c|c|c|c|}
\hline & 2006 & 2007 & 2008 & 2009 & 2010 & 2011 & 2012 \\
\hline \multicolumn{8}{|c|}{ Chilean demographics in number of habitants } \\
\hline Live births & 231,383 & 240,569 & 246,581 & 252,240 & 250,643 & 247,358 & 243,635 \\
\hline \multicolumn{8}{|l|}{ Children by age in months } \\
\hline$<12$ & 230,900 & 235,457 & 242,535 & 248,363 & 250,453 & 248,203 & 244,493 \\
\hline $12-23$ & 230,667 & 231,072 & 235,687 & 242,775 & 248,628 & 250,790 & 248,599 \\
\hline $24-47$ & 470,108 & 464,090 & 462,670 & 467,807 & 479,556 & 492,626 & 500,837 \\
\hline \multicolumn{8}{|c|}{ Percentage of population in the public health system } \\
\hline Live births & 70.4 & 68.7 & 69.2 & 68.1 & 68.5 & 66.3 & 64.7 \\
\hline Pregnancies per live birth & 76.0 & 81.5 & 82.2 & 79.6 & 78.9 & 79.4 & 77.0 \\
\hline \multicolumn{8}{|l|}{ Children by age in months } \\
\hline$<12$ & 70.5 & 69.3 & 69.6 & 70.9 & 69.2 & 69.4 & 69.4 \\
\hline $12-23$ & 72.4 & 72.7 & 73.9 & 74.2 & 74.6 & 73.6 & 72.3 \\
\hline $24-47$ & 69.2 & 68.7 & 69.7 & 70.4 & 70.7 & 70.3 & 69.2 \\
\hline \multicolumn{8}{|c|}{ Percentage of population who benefited from Chile crece contigo } \\
\hline Live births & 0.0 & 16.7 & 69.2 & 68.1 & 68.5 & 66.3 & 64.7 \\
\hline Pregnancies per live birth & 0.0 & 19.8 & 82.2 & 79.6 & 78.9 & 79.4 & 77.0 \\
\hline \multicolumn{8}{|l|}{ Children by age in months } \\
\hline$<12$ & 0.0 & 0.0 & 69.6 & 70.9 & 69.2 & 69.4 & 69.4 \\
\hline $12-23$ & 0.0 & 0.0 & 73.9 & 74.2 & 74.6 & 73.6 & 72.3 \\
\hline $24-47$ & 0.0 & 0.0 & 0.0 & 70.4 & 70.7 & 70.3 & 69.2 \\
\hline
\end{tabular}

Source: DEIS(2006-2012), INE(2006-2012)

health system received ChCC benefits. Finally, in 2009, the policy expanded its services to children under 4 years old in the public health system.(52) As shown in Table 3.1, these children represent nearly $70 \%$ of all Chilean children under 4 years old.

Further, during the period of implementation, the policy suffered additional adjustments, which expanded its services and improved its monitoring(See timeline on Figure 3.1). Thus, ChCC started with: monitoring of mother's health and child's development, home visits, education on parenting and children development, free didactic materials, stimulation sessions, and preferential access to public social programmes. Most of these actions belong to the PADBP, and are executed by health facilities and basic community networks ${ }^{4}$. ChCC added the distribution of nutritional supplements for pregnant women through the National Programme of Complementary Food (PNAC in Spanish) in 2008, and a package of free clothes and other child rearing materials to all babies born in the public health system in 2009 (New Born Healthcare Programme - PARN in Spanish). Later, in September of that year, the National Congress approved the Law 20379, that regulates ChCC benefits, its monitoring and evaluation. Finally, other minor measures were implemented

${ }^{4}$ The PADBP is carried out by the Ministry of Health. Its main task is to monitor and give personalized support to children in the pubic health system. Once a child or pregnant woman is identified and diagnosed, the PADBP either defines actions executed by the health staff e.g. home visits, specialists consults, stimulation sessions, or activates targeted benefits that require the involvement of other sectors, such as education and social services. On the other hand, the Basic Community Network is a district-level coordination unit which joins relevant institutional actors for the provision of goods and services directed to the children, e.g. family health centre directors, public nurseries directors, municipal social services unit. They gather to define a yearly plan with inter-sectoral goals based on the needs of district children and pregnant women. $(52,55)$ 
between 2009 and 2010, such as the distribution of free stimulation packages, changes in the content of the prenatal workshops, promotion of breastfeeding to midwives, new home visits manuals, and a new methodology for parenting workshops -"nobody is perfect" (Nadie es perfecto in Spanish).(52, 55)

Figure 3.1: Timeline of the implementation of the social protection system

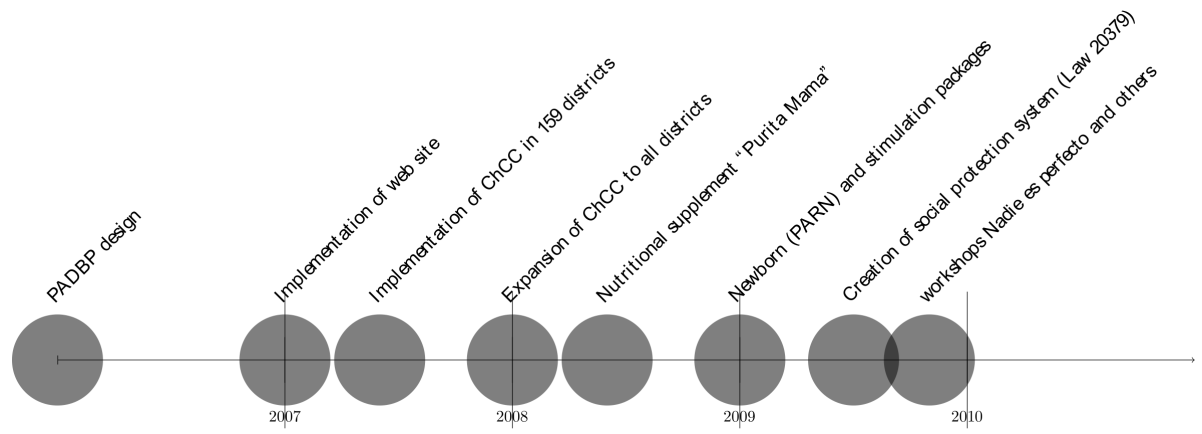

ChCC actions vary according to the vulnerability of each child and her family. Initially, ChCC offers a basic package destined to all mothers and children under five in the public health system ${ }^{5}$. But it also has several combinations of complementary packages which activate depending on specific child and family vulnerabilities. On the one hand, the basic package contains: (i) regular health controls to assess potential family vulnerabilities, mother's mental health and child's development risks, delays and deficits, (ii) free rearing and didactic materials for children development, (iii) nutritional supplements for mothers, and (iv) education on pregnancy topics and parenting during consults or group sessions at health facilities ${ }^{6}$.(55) A child with normal development and no family vulnerabilities has monthly controls from gestation to the fourth month of life. The next controls are at the sixth, eighth, twelfth and eighteenth month of life. After that, the controls become annual.(57)

On the other hand, the complementary packages consist of home visits, access to technical assistance at health facilities, free access to nurseries and daycares and preferential access to other social programmes. The home visits consist of therapeutic/educational sessions for parents and children conducted in the house by a health professional and a paramedic technician ${ }^{7}$. The purpose of the sessions is to address the vulnerabilities identified during health controls.

${ }^{5}$ Recently, ChCC expanded to children up to 9 years old.(57)

${ }^{6}$ Parenting workshops consist of six group meetings where parents and workshop facilitator discuss rearing experiences, learn from each other, and receive orientations respect to specific child development issues. Among the usual discussion topics are: how to comfort a crying child, answer effectively to tantrums, foster language, security, independence, etc.

${ }^{7}$ Duration, frequency of home visits and the health professional in charge depend on the situation of each family. Each home visit lasts between 60 to 90 minutes, and the whole process can last between four months to two years. The professionals attending the home visits usually are nurses, midwives, doctors, social workers, psychologists, occupational therapists, educators and nutritionists.(58) 
Vulnerability is determined by a group of test, which evaluates the following factors: family environment, maternal mental health, maternal attachment, and child developmental delays ${ }^{8}$. Table 3.2 offers details on these tests. If we are evaluating factors related with family environment, it is enough to identify one of them, e.g. suspicion of domestic violence, to do a home visit. Otherwise, the decision to do a home visit depends on mother or child not reaching certain thresholds of psychometric tests. According to ChCC statistics, in 2012, near $40 \%$ of pregnant women had at least one risk associated with their family environment and $6 \%$ of children presented risks or deficits in development ${ }^{9}$.

The remaining $\mathrm{ChCC}$ benefits are regulated by the Intersectoral Social Protection System law (law № 20379). According to this law, all vulnerable pregnant women should access to Chile Solidario ${ }^{10}$. In addition, $60 \%$ of the socioeconomically most vulnerable families are entitled to access to technical aids for children with disabilities, and free access to daycares and nurseries. Likewise, $40 \%$ of the socioeconomically most vulnerable families have preferential access to other social programmes such as remedial education, employment insertion, improvement of housing and living conditions, mental health care, judicial assistance, prevention of child abuse, etc. (54) Families are granted access to these benefits through the social protection card, that determines to which percentile a family belongs to. This instrument is explained in Table 3.2. The specific course of action for each family is determined locally by the basic community network, which connects the families with other social programmes. $(52,51)$ There is no stantardized procedure to do that. So far, in 2012, the most common benefits among families in the public health system were public subsidies for pregnant women(60\%), other Chile Solidario benefits $(26 \%)$, access to nurseries and daycares (near 30\%), mental health care (11\%), and improvement of living conditions $(10 \%)^{11}$. (51)

Table 3.3 shows ChCC's potential outcomes, given its main actions. The idea behind $\mathrm{ChCC}$ is that health controls, home visits and other actions should aid the improvement of the family environment and parenting skills, which later lead to increases in child's cognitive and non-cognitive skills. ChCC ac-

${ }^{8}$ Contingent on these vulnerabilities, the health professional gives support, encouragement and information to overcome family problems; helps to build safe relationship between parents and children; models parent-children interactive games for children stimulation or gives specific reinforcements for children with development delays, among others. In addition, home visits allow the early detection of other potential risks.(58)

${ }^{9}$ See these statistics in table C. 1

${ }^{10}$ Chile Solidario is part of Chile's social protection system and grants monetary and non-monetary aids to families without socioeconomic support.

${ }^{11}$ This information was obtained from the study of Asesorias para el Desarrollo, which considers a sample from the $15 \%$ top and $15 \%$ bottom of the distribution of districts ranked by the degree of ChCC implementation. 
Table 3.2: Instruments and factors to determine vulnerability

\begin{tabular}{|c|c|}
\hline Instrument & Description \\
\hline 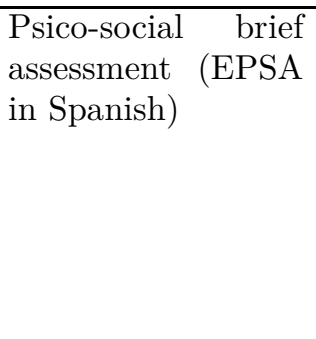 & $\begin{array}{l}\text { Questionnaire for pregnant women to identify the following } \\
\text { psycho-social risks: } 1 \text {. Suspect of maternal/paternal depres- } \\
\text { sion } 2 \text {. Suspect of domestic violence } 3 \text {. Insufficient family } \\
\text { support, social isolation } 4 \text {. Drugs and alcohol abuse } 5 \text {. Con- } \\
\text { flicts with motherhood } 6 \text {. Teenage mother } 7 \text {. Less than pri- } \\
\text { mary education } 8 \text {. First pre-natal control after } 20 \text { weeks of } \\
\text { gestation . If at least one of the risk is present, the women } \\
\text { is considered vulnerable. }\end{array}$ \\
\hline $\begin{array}{l}\text { Edinburgh postna- } \\
\text { tal depression scale }\end{array}$ & $\begin{array}{l}\text { Answered by the mother during the first year of life of the } \\
\text { child. It consists of ten short statements. Mother chooses } \\
\text { which of the four possible answers - always, sometimes, } \\
\text { rarely, never - is the one that most closely resembles the } \\
\text { way she felt in the week before. A score higher than } 10 \\
\text { indicates possible depression. }\end{array}$ \\
\hline $\begin{array}{l}\text { Mass-Campbell } \\
\text { scale }\end{array}$ & $\begin{array}{l}\text { Applied in the first year of life. It measures mother-child } \\
\text { attachment during stress based on } 6 \text { parameters: gazing, } \\
\text { affective sharing, vocalizing, touching infant, clinging ma- } \\
\text { ternal holding, and physical proximity. These components } \\
\text { are graded for the intensity of the attraction or avoidance } \\
\text { between a mother and baby the baby's response. }\end{array}$ \\
\hline $\begin{array}{l}\text { Brief psycho-motor } \\
\text { development test }\end{array}$ & $\begin{array}{l}\text { Applied to children under } 2 \text { years old. It contains an in- } \\
\text { ventory of four actions/characteristics that predict the de- } \\
\text { velopment status by age. Each predictor corresponds with } \\
\text { one area of development: motor, coordination, social and } \\
\text { language. If a child satisfies all of them, he has an adequate } \\
\text { development status. }\end{array}$ \\
\hline $\begin{array}{l}\text { Evaluation Scale of } \\
\text { Psycho-motor De- } \\
\text { velopment (EEDP } \\
\text { in Spanish) }\end{array}$ & $\begin{array}{l}\text { Applied to children under } 2 \text { years old. Similar to the previ- } \\
\text { ous test, but more extensive. It contains } 75 \text { items, divided } \\
\text { in the four areas of development mentioned before. The fi- } \\
\text { nal score is standardised and then, children are classified } \\
\text { into three groups: normal development, at risk, delayed de- } \\
\text { velopment. }\end{array}$ \\
\hline $\begin{array}{l}\text { Psycho-motor } \\
\text { Development test } \\
\text { (TEPSI in Spanish) }\end{array}$ & $\begin{array}{l}\text { Applied to children between } 2 \text { to } 5 \text { years old. Similar charac- } \\
\text { teristics to the previous test. Evaluates three development } \\
\text { areas: motor, coordination and language. }\end{array}$ \\
\hline $\begin{array}{l}\text { Ministry of health } \\
\text { normative }\end{array}$ & $\begin{array}{l}\text { Other factors considered during health controls are: signs of } \\
\text { child abuse, other parents' mental disorders, low adherence } \\
\text { to health controls, undernourishment and risk of death. }\end{array}$ \\
\hline $\begin{array}{l}\text { Social Protection } \\
\text { Card }\end{array}$ & $\begin{array}{l}\text { It assigns a score based on the revenue-generation capacity } \\
\text { of family members adjusted by the level of economic needs. } \\
\text { Revenue-generation capacity is calculated based on school } \\
\text { years, working experience, affiliation and variables of the } \\
\text { economic environment, such as unemployment rate and } \\
\text { district or regional characteristics. }\end{array}$ \\
\hline
\end{tabular}

Source: $(52,57,59)$

tions during pregnancy contribute to a higher involvement of family members in child rearing, particularly the father of the child. They could also improve mother-child bonding and mother's socio-emotional skills, e.g. reduce maternal post-partum depression. Further, ChCC actions after child's birth build on outcomes from pregnancy period actions. Family interrelationships and maternal attachment are expected to improve. The latter, together with 
mother's nutritional supplements and information at health controls, should enhance breastfeeding practices. In addition, ChCC actions help on the development of a safe parents-child relationship, and provide parents with tools to deal with child behaviour problems, which should reduce child abandonment or abuse. Finally, stimulation sessions for the child at health facilities and games/routines/exercises applied by parents at home should develop children's cognitive and non-cognitive skills.

Table 3.3: Outcomes of Chile crece contigo for families in the public health system

\begin{tabular}{ll}
\hline \hline \multicolumn{2}{c}{ Intermediate outcomes } \\
\hline Pregnant women & \multicolumn{1}{c}{ Children under 5 years old } \\
\hline i) more involvement of the father or & i)increase in mother-child bonding, \\
close family members during prena- & improvement of breastfeeding prac- \\
tal care and childbirth, ii) reduction & tices, ii) improvement of parenting \\
of post-partum depression rates, iii) & skills to deal with child behavioural \\
improvement of mother's nutritional & problems, iii) reduction of child \\
status & abandonment rates and child abuse, \\
& iv) increase of parent-child activities \\
& to stimulate psycho-motor develop- \\
& ment, v) increase in the adoption of \\
& healthy habits to improve physical \\
& development, vi) increase in the use \\
& of public nurseries and day cares. \\
\hline
\end{tabular}

i) improvement of child's physical development, ii) improvement of child's cognitive and non-cognitive skills, iii) reduction of the gap on infant development between vulnerable and non-vulnerable families, iv) long term improvements in human capital

Source: Own elaboration based on $(52,55)$

\section{3}

\section{Empirical strategy and Data}

\subsection{1}

Data

We use the 2010 and 2012 Longitudinal Early Childhood Survey of Chile. The ELPI is a detailed survey which contains multiple measures of children and parents cognitive and socio-emotional skills, parental investments, and socio-demographic variables.

The first round of ELPI surveyed a sample of nearly 15000 children who were less than 5 years old in 2010(56). These children were followed in the 2012 ELPI forming the panel section of our dataset. Moreover, during the second round, approximately 3000 new children were included in the sample in order to characterise younger cohorts. Within this group we identify cohorts 
conceived before and after the programme implementation, which is January of 2008. As explained in our programme description section, families which use the public health services are the main recipients of $\mathrm{ChCC}$, so we restricted our sample to children born in the public health system.

First we divide our sample into two subgroups these conceived before and after ChCC. Then we restrict our sample to age groups that contain comparable measurements of all variables of interest, cognitive socio-emotional skills, for both pre-ChCC and post-ChCC cohorts. This leaves us with children 18 to 23 months old, 36-47 months old ${ }^{12}{ }^{13}$. We proceed to estimate all equations separately for these two remaining age groups as they differ in terms of stage of development and in terms of actions related ChCC programme.

We are interested in determining the effect of the programme in intermediate outcomes, mainly measures of parental investment and parents' socioemotional skills, and final outcomes, i.e. measures of children development. We use the Big Five Inventory (BFI) of the main carer to approximate changes in parents' socio-emotional skills. This test contains 44 items to measure the five main personality traits: neuroticism, extroversion, kindness, responsibility and openness to experience(56). Secondly, we use a group of questions that asks about parents-child activities in the week previous to the interview to approximate parental investment ${ }^{14}$.

Finally, in order to evaluate different aspects of child development we use the Battelle Development Inventory (BDI), the Peabody Image Vocabulary test and the Child Behaviour Check List (CBCL). The BDI evaluates five developmental areas: adaptive, personal-social, communication, motor and cognitive, whereas the CBCL identifies seven potential mental problems, that characterise children internal and external behaviour: Emotional Reactivity, Anxiety / Depression, Somatic Complaints, Self-absorption, Sleep Problems, Attentional Problem and Aggressive conduct. The first five are associated to internal behaviour, and the last two, to external behaviour. All these variables have been standardised using age-specific means and standard deviations of the pre-ChCC group. In that way, cohorts and children of different ages are comparable. To reduce the sensitivity to outliers and small sample sizes within age categories, we compute the age conditional means and standard deviations using a kernel-weighted local polinomial smoothing method, as in $(28,18)$.

\footnotetext{
${ }^{12}$ We also excluded children of 30-35 months of age from our analyses as we could not secure identification of our production function parameters as our investment instrument did not display significant variation.

${ }^{13}$ See appendix for the distribution of children by year of interview and cohort.

${ }^{14}$ We are not able to use the ELPI HOME inventory because the version of the inventory questionnaire changes between 2010 and 2012
} 
Table 3.4 and 3.5 show descriptive statistics by age-group and cohort. As shown in table 3.4, within each age group almost all the socio-demographic characteristics between pre and post ChCC groups are similar. The exceptions are the parents education and the family per capita income, which are higher for the child conceived after the programme implementation. This is because both variables, ChCC status and family income, are likely to increase with time. In fact, if we measure them on a fixed date, these differences become non-significant (See 2010 income and education in the appendix).

Table 3.4: Descriptive Statistics - Socio-demographic characteristics

\begin{tabular}{|c|c|c|c|c|c|c|}
\hline & \multicolumn{3}{|c|}{ 12-23 months } & \multicolumn{3}{|c|}{ 36-47 months } \\
\hline & pre-ChCC & post-ChCC & P-val & pre-ChCC & post-ChCC & $\mathrm{P}$-val \\
\hline \multicolumn{7}{|l|}{ Other parents skills: } \\
\hline Working memory & 0.02 & -0.07 & 0.08 & 0.02 & -0.01 & 0.44 \\
\hline Vocabulary & 0.07 & -0.14 & 0.02 & 0.07 & 0.05 & 0.52 \\
\hline Mother education & 10.56 & 11.11 & 0.01 & 10.65 & 11.01 & 0.00 \\
\hline Father education & 10.55 & 11.09 & 0.01 & 10.62 & 10.89 & 0.00 \\
\hline Height & -0.01 & -0.04 & 0.88 & -0.01 & 0.01 & 0.69 \\
\hline Weight & -0.09 & 0.02 & 0.25 & -0.03 & 0.05 & 0.01 \\
\hline \multicolumn{7}{|l|}{ Socio-demographic vars. } \\
\hline Gestation in weeks & 0.02 & -0.01 & 0.69 & -0.00 & 0.00 & 0.94 \\
\hline Birth height & -0.06 & -0.08 & 0.73 & 0.03 & -0.05 & 0.01 \\
\hline Birth weight & 0.02 & -0.05 & 0.21 & 0.02 & -0.03 & 0.12 \\
\hline Sex of the child & 0.50 & 0.50 & 0.92 & 0.51 & 0.51 & 0.89 \\
\hline Main caregiver's age & 27.55 & 28.09 & 0.22 & 30.04 & 29.64 & 0.08 \\
\hline Minors $<7$ & 1.43 & 1.44 & 0.86 & 1.40 & 1.41 & 0.83 \\
\hline Minors $>7$ & 0.78 & 0.79 & 0.86 & 0.80 & 0.77 & 0.29 \\
\hline Parents live together & 0.62 & 0.66 & 0.41 & 0.65 & 0.64 & 0.42 \\
\hline Per capita income & 11.10 & 11.21 & 0.07 & 11.15 & 11.32 & 0.00 \\
\hline 2010 p.c. income $(\operatorname{logs})$ & 11.10 & 11.06 & 0.41 & 11.12 & 11.06 & 0.01 \\
\hline 2010 Mother educ. (in years) & 10.56 & 10.62 & 0.81 & 10.57 & 10.57 & 0.98 \\
\hline 2010 Father educ. (in years) & 10.55 & 10.76 & 0.28 & 10.54 & 10.56 & 0.82 \\
\hline Observations & 904 & 906 & 1240 & 3089 & 2066 & 4626 \\
\hline
\end{tabular}

Table 3.5 shows significant positive differences in outcomes between children conceived after and before the programme implementation. Although, not all of them change. On one hand, we observe a consistent improvement across all age groups in variables that measure socio-emotional skills, and parent-child activities. On the other hand, we observe a decrease the Peabody Vocabulary test for children of 36-47 months of age. Other variables, such as main carer neuroticism index, improve for some age groups.

\subsection{2}

\section{Empirical strategy}

The evaluation of the ChCC system is a challenge. ChCC is a national scale programme that was not designed as a randomised control trial this 
Table 3.5: Descriptive Statistics - Potential programme outcomes

\begin{tabular}{|c|c|c|c|c|c|c|}
\hline & \multicolumn{3}{|c|}{ 18-23 months } & \multicolumn{3}{|c|}{ 36-47 months } \\
\hline & pre-ChCC & post-ChCC & P-val & pre-ChCC & post-ChCC & P-val \\
\hline \multicolumn{7}{|l|}{ Child development: } \\
\hline Psycho-motor test & -0.00 & 0.67 & 0.00 & & & \\
\hline Vocabulary & & & & 0.00 & -0.19 & 0.00 \\
\hline (-)Internal behaviour & -0.01 & 0.43 & 0.00 & -0.00 & 0.31 & 0.00 \\
\hline (-)External behaviour & -0.00 & 0.36 & 0.00 & -0.00 & 0.35 & 0.00 \\
\hline \multicolumn{7}{|l|}{ Parental investment: } \\
\hline Reads books to the child & -0.00 & 0.12 & 0.44 & -0.00 & 0.25 & 0.00 \\
\hline Tells stories to the child & -0.00 & 0.21 & 0.02 & -0.00 & 0.28 & 0.00 \\
\hline Sings to the child & 0.00 & 0.23 & 0.00 & -0.00 & 0.28 & 0.00 \\
\hline Visits parks, museums, etc. & 0.00 & 0.14 & 0.49 & 0.00 & 0.14 & 0.00 \\
\hline Talks and draws with the child & 0.00 & 0.28 & 0.00 & -0.00 & 0.40 & 0.00 \\
\hline Child time in pre-school since birth & & & & 0.00 & 0.23 & 0.00 \\
\hline Parents' socio-emotional skills: & & & & & & \\
\hline (-)Neuroticism & 0.06 & 0.18 & 0.06 & -0.00 & -0.01 & 0.95 \\
\hline Extraversion & 0.09 & 0.02 & 0.12 & 0.01 & -0.00 & 0.67 \\
\hline Kindness & 0.06 & 0.07 & 0.87 & 0.00 & -0.02 & 0.43 \\
\hline Responsibility & 0.06 & 0.00 & 0.17 & 0.03 & -0.09 & 0.00 \\
\hline Opening to Experience & 0.06 & 0.01 & 0.31 & 0.02 & -0.02 & 0.20 \\
\hline Observations & 904 & 906 & 1760 & 3089 & 2066 & 4907 \\
\hline
\end{tabular}

imposes restrictions on our ability to identify pure programme effects. We attempt to answer this issue by choosing a conservative empirical strategy.

By choosing a cut-off date of conception before and after January 2008 we are comparing individuals with different time of exposition to ChCC. We chose conception dates in place of birth dates because the policy has a strong prenatal care component. Thus individuals in the post-ChCC cohort have benefited from $\mathrm{ChCC}$ as whole while those in the pre-ChCC cohorts have still partially benefited from the policy. In figure 3.2 we see that for ages 18-23 months the pre-ChCC group is composed of individuals with conception dates which are very close to our cut-off point January 2008, meaning that those individuals were not exposed to $\mathrm{ChCC}$ during gestation or at most up until the first months of life. For individuals aged 36-47 months we have that the majority of individuals in pre-ChCC cohort we conceived around January 2006, this means these individuals began exposition to the policy around 1 year and 3 months. In both case we expect that this will generate an estimated effects of the exposure to the policy during gestation.

The implementation of ChCC happened in two stages it was first implemented in June 2007 in just under half of Chilean districts and then in January 2008 in all remaining districts. Our data does not contain information on district of residence. By choosing a cut-off date of January 2008 we include inhabitants of the pilot districts that have benefited from ChCC since conception in our "control" group. Thus our analysis is likely to suffer from attenuation 
Figure 3.2: Sample distribution
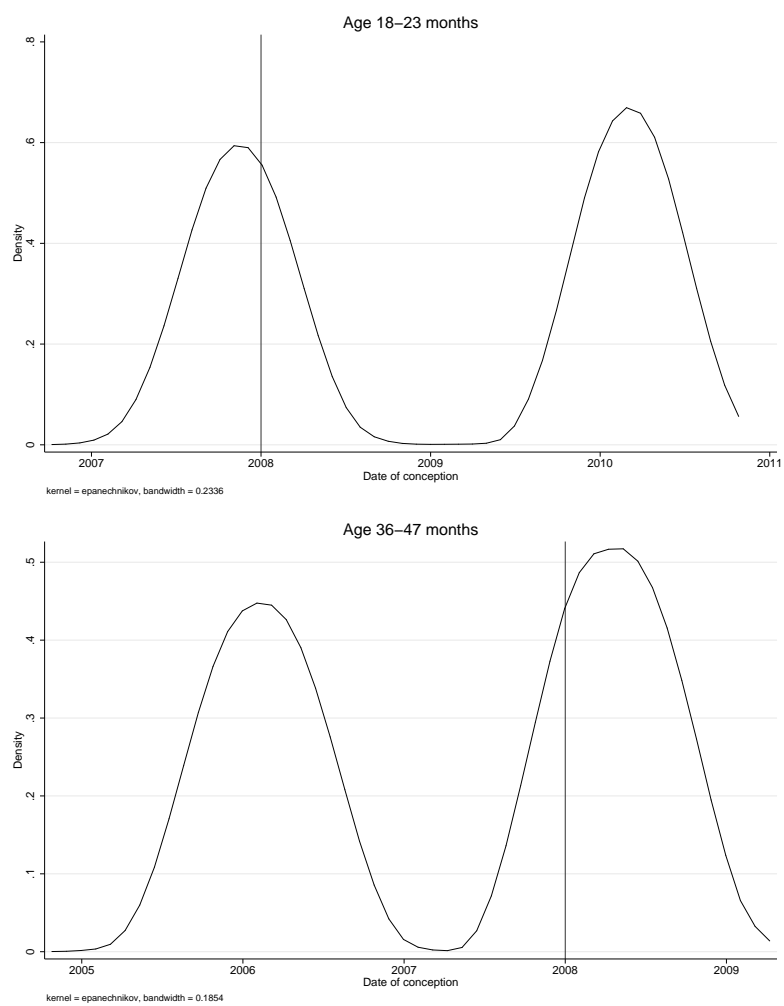

bias. Additionally, the implementation of ChCC happened first in districts with better infrastructure and maternity centre management capacities(52). Also, the availability of non-physician professionals, such as psychologists and social workers, conditioned the implementation of the policy(50). Our placement of these individuals in the pre-ChCC cohort generates further attenuation of results.

We have chosen to exclude from both pre and post-ChCC cohorts individuals who were not delivered in public health facilities. We did this as ChCC is mainly implemented through public institutions. The exclusion results in a group of individuals who are more similar in observable characteristics, such as income, family composition amongst others.

The comparison of cohorts before and after the complete implementation of the programme, as we undertake here, could face biases from differences between cohorts that are not related to ChCC. However, as we compare cohorts with a mean difference of two and half years between them, we expect these effects to be small. Finally, using the ELPI 2010 and 2012, and the early ChCC implementation starting in 2007 we have at maximum 5 years of implementation of the programme. It thus likely some of the programme's effects are only now beginning to crystallise.

The advantage of estimating a non-linear production function of child 
abilities is that organises within a defined theoretical framework the possible mechanism behind the policy's effect. Further it allows to recuperate not only point estimates of effects but distributions giving us the ability to perform contra-factual exercises to better assess the policy. Finally, our methodology uses common variances between various measurements that reflect a given latent trait. This, as it will be detailed later in the article, reduces bias due to measurement error in the data.

\section{4}

\section{Structural modelling and estimation}

This section is divided into two sub-sections. The first section details the production function we wish to estimate. The second section is devoted to its estimation, it explains the econometric problems we face and our estimation procedure.

\subsection{1}

\section{The model}

Our model is based on the seminal article of Cunha, Heckman and Schennach(1). They develop a theoretical and empirical framework where the child's abilities depend of a technology of production, parental abilities, previous period abilities and parental investments.

We define a production function for three types of abilities given by $\Theta=$ $\left[\theta^{c}, \theta^{s}, \theta^{e}\right]$, where $\theta^{c}, \theta^{e}, \theta^{s}$ represents cognitive skills external socio-emotional skills, and internal socio emotional skills, respectively. The separation between external and internal socio-emotional skills represents an innovation in terms of existing production function literature. The field of child psychology has long distinguished between "internalising" and "externalising" disorders (21). The former reflecting the child negatively acting on the external environmental stimuli and the latter reflecting problems with the child's internal psychological environment. Examples of externalising behaviour problems are aggressiveness, attentional deficits and hyperactivity while examples of internalising behaviour include anxiety, depression and inhibition. We are particularly interested in the external component of CBCL as external behaviour problems are linked to executive functioning of the brain $(22,23)$. Executive function consists of four principle dimensions: i) attentional control ii) information processing iii) cognitive flexibility iv) goal setting. All contribute to determining a child's cognitive function behaviour, emotional control and social interaction. Attentional control, subdivided into processes of selective attention, selfregulation, self-monitoring and inhibition, appears to emerge in infancy and 
develop in early-childhood. The remaining three dimensions develop and mature at later stages of childhood (24). Although the ECD literature has not distinguished between "internalising" and "externalising" mental health, it has begun to measure EF as a separate skill from socio-emotional and cognitive skills $(25,26)$.

As we wish to check whether Chile Crece Contigo affected the parameters governing the production function abilities, we let the production function vary between pre and post-ChCC cohorts, denominated by the superscript $d$. The production function also varies by age group $a$. We consider the two age groups described in data section: 18-23 months and 36-48 months of age.

The production function describes the formation of child abilities in two moments of time. The initial moment is child's birth, which we denote as $t=t_{0}$. The second moment, which we denote as $t=t_{1}$, is when ELPI survey was collected, that could be one or three years after birth depending on the age group the child belongs to. We assume a CES technology in the production of abilities, where child's current ability $\boldsymbol{\Theta}_{t_{1}}$ is a result of the combination of a vector of parental cognitive, socio-emotional skills and parental health $\boldsymbol{\Omega}=\left[\omega^{c}, \omega^{s}, \omega^{h}\right]$, child's initial skills $\theta_{t_{0}}$, parental investment $i_{t_{1}}$, and a factorneutral productivity parameter $A_{t_{1}}^{a, d}$. Our production functions of each of the three dimensions of child skills are depicted below in matrix notation.

$$
\boldsymbol{\Theta}_{t_{1}}=A_{t_{1}}^{a, d}\left[\gamma_{1}^{a, d}\left(i_{t_{1}}\right)^{\phi^{a, d}}+\gamma_{2}^{a, d}\left(\theta_{t_{0}}\right)^{\phi^{a, d}}+\gamma_{3}^{a, d}(\boldsymbol{\Omega})^{\phi^{a, d}}\right]^{\frac{1}{\phi^{a, d}}}
$$

where the production function parameters $\gamma_{1}^{a, d}, \gamma_{2}^{a, d}, \gamma_{3}^{a, d}, \phi^{a, d}$ are matrices of the same length as $\boldsymbol{\Theta}_{t_{1}}$, and $A_{t_{1}}^{a, d}$ is given by the following expression which depends on a set of controls $\boldsymbol{X}_{t_{1}}$ and a random shock $u_{t_{1}}^{a, d}$ :

$$
A_{t_{1}}^{a, d}=\exp \left(\delta_{1}^{a, d}+\delta_{2}^{a, d} \boldsymbol{X}_{t_{1}}+u_{t_{1}}^{a, d}\right)
$$

The advantage of this functional form is that we do not have to assume an specific degree of substitutability between the inputs of our production function. The parameter $\phi^{a, d} \in(-\infty, 1]$ determines the elasticity of substitution, that is given by $\frac{1}{1-\phi^{a, d}}$.

We adopt a logarithm version of our model as in Attanasio et al (19). The equation to be estimated is thus:

$$
\begin{aligned}
\ln \boldsymbol{\Theta}_{t_{1}}=\frac{1}{\phi^{a, d}} \ln \left[\gamma_{1}^{a, d}\left(i_{t_{1}}\right)^{\phi^{a, d}}+\gamma_{2}^{a, d}\left(\theta_{t_{0}}\right)^{\phi^{a, d}}+\gamma_{3}^{a, d}(\boldsymbol{\Omega})^{\phi^{a, d}}\right] & \\
& +\delta_{1}^{a, d}+\delta_{2}^{a, d} \boldsymbol{X}_{t_{1}}+u_{t_{1}}^{a, d}
\end{aligned}
$$




\subsection{2}

\section{Estimation}

The estimation of our non-linear production function is complex. We face two challenges: the regressors are non-observables, and parental investments may be endogenous. The variables of our function: cognitive abilities, socioemotional abilities, health and parental investments are latent traits. We do not observe them directly, but instead we have a variety of measures in our dataset that reflect these traits. Hence we need to develop a model that relates the measures in our data and our latent variables in a manner that permits non-linear relationship between our latent variables.

The second problem with the estimation of our production function is that parental investments may suffer from endogeneity. This is because when parents make their investment decisions they may take into account random shocks to the child's ability. For example, if a child falls sick her parents may invest more in her to offset this negative shock, or act in a way to reinforce it.

In the next subsections we explain our estimation procedure, which deals with the non-observability and endogeneity problems, and follows Attanasio et. al.(19). Our estimation consists of three steps. In the first step, we estimate the distribution of our measurements, separately for pre and post ChCC cohorts. We then, use the distribution of measurements to reover the distribution of latent factors. This is done again for pre and post ChCC cohorts. In the final step, using the distribution of latent factors we draw a synthetic dataset and apply non-linear least squares to estimate our non-linear production functions.

\subsubsection{1}

\section{A factor structure between measurements and latent variables}

The principle challenge with our estimation is the fact that our latent traits are non-observable. Hence we need to model the relationship between our measurements and our latent factors. Denote our latent factors by $\boldsymbol{\Psi}=$ $\left[\boldsymbol{\Theta}_{t_{1}}, i_{t_{1}}, \theta_{t_{0}}, \boldsymbol{\Omega}, \mathbf{X}_{t_{1}}\right]$. We assume a factor structure between latent variables and measurements, where each measurement has a component associated with the latent factor and a component which is purely noise. The intuition behind factor models, such as ours, is that the common variance between our measurements is attributed to the latent factor they all reflect, while the remaining variance is the noise. The factor structure for each measurement is related to latent variables $\boldsymbol{\Psi}$ as follows: 


$$
\begin{aligned}
M^{\boldsymbol{\Theta}_{t_{1}}, a, d} & =\beta^{\boldsymbol{\Theta}_{t_{1}}, a, d}+\lambda^{\boldsymbol{\Theta}_{t_{1}}, a, d} \ln \left(\boldsymbol{\Theta}_{t_{1}}\right)+\epsilon_{\boldsymbol{\Theta}_{t_{1}}, a, d} \\
M^{\theta_{t_{0}}, a, d} & =\beta^{\theta_{t_{0}}, a, d}+\lambda^{\theta_{t_{0}}, a, d} \ln \left(\theta_{t_{0}}\right)+\epsilon_{\theta_{t_{0}}, a, d} \\
M^{i_{t_{1}}, a, d} & =\beta^{i_{t_{1}}, a, d}+\lambda^{i_{t_{1}}, a, d} \ln \left(i_{t_{1}}\right)+\epsilon_{i_{t_{1}}, a, d} \\
M^{\boldsymbol{\Omega}, a, d} & =\beta^{\boldsymbol{\Omega}, a, d}+\lambda^{\boldsymbol{\Omega}, a, d} \ln (\boldsymbol{\Omega})+\epsilon_{\boldsymbol{\Omega}, a, d} \\
M^{\mathbf{X}_{t_{1}}, a, d} & =\mathbf{X}_{t_{1}}^{a, d}
\end{aligned}
$$

where $\quad M^{\boldsymbol{\Theta}_{t_{1}}, a, d}, M^{\theta_{t_{0}}, a, d}, M^{i_{1}, a, d}, M^{\boldsymbol{\Omega}, a, d}, M^{\mathbf{X}_{t_{1}}, a, d} \quad$ are $\quad$ vectors $\quad$ of measurements, $\beta^{\theta_{t_{1}}, a, d}, \beta^{\theta_{t_{0}}, a, d}, \beta^{i_{1}, a, d}, \beta^{\boldsymbol{\Omega}, a, d}$ are vectors of measurement means, $\quad\left[\lambda^{\theta_{t_{1}}, a, d}, \lambda^{\theta_{t_{0}}, a, d}, \lambda^{i_{t_{1}}, a, d}, \lambda^{\boldsymbol{\Omega}, a, d}\right] \equiv \Lambda$ are factor loadings and $\epsilon_{\boldsymbol{\Theta}_{t_{1}}, a, d}, \epsilon_{\theta_{t_{0}}, a, d}, \epsilon_{i_{1}, a, d}, \epsilon_{\boldsymbol{\Omega}, a, d}$ are idiosyncratic error terms. Notice that $\theta_{t_{1}}, i_{t_{1}}, \theta_{t_{0}}, \boldsymbol{\Omega}$ are measured with error whereas the control variables, $\mathbf{X}_{t_{1}}$, are measured without error.

In order to identify the parameters of the measurement system, we assume that errors are orthogonal to latent variables and normalise our system by setting the factor loading coefficient of the first measurement of each latent variable to one, as the extant literature does. Further, we assume that errors are independent amongst themselves ${ }^{15}$.

At this point, we remind the reader that we wish to recover the distribution of latent factors for control and treatment groups. It is standard to assume normal distributions for all errors and measurements, which implies that latent factors also are multivariate normally distributed. Multivariate normal distribution implies that any linear combination of its components, latent variables, is also normally distributed. This implies linear conditional means of children abilities given other latent traits, ruling out a non-linear production function. In order to add enough flexibility we assume latent factors are drawn from a mixture of two normal distributions, as done by Attanasio et al $(19)^{16}$. We also assume that the errors of the equations above are normally distributed. We thus have:

$$
\begin{gathered}
\epsilon \sim N\left(0, \Sigma^{\epsilon}\right) \\
f_{a, d}(\ln \Psi)=\tau_{a, d} f_{a, d}^{1}(\ln \Psi)+\left(1-\tau_{a, d}\right) f_{a, d}^{2}(\ln \Psi)
\end{gathered}
$$

${ }^{15}$ This assumption can be relaxed, as shown in (1). However, we do not explore this possibility on this paper.

${ }^{16}$ Attanasio et al (2015) test mixed normal distributions with more than two components but revert to the two component normal mixture. The gain from adding mixtures is small when compared to the computational burden of such choices 
where $f_{a, d}^{1}$ and $f_{a, d}^{1}$ are multivariate normal distribution and $\tau$ represents the weight of each distribution.

Given the above equations and our measurements to latent factor structure we can derive the following formula for our distribution of measurements:

$$
\begin{aligned}
& f\left(\tilde{m}_{a, d}\right)=\tau_{a, d} \int g\left(\Lambda \ln \Psi-\tilde{m}_{a, d}\right) f_{a, d}^{1}(\ln \Psi) d \ln \Psi \\
& \quad+\left(1-\tau_{a, d}\right) \int g\left(\Lambda \ln \Psi-\tilde{m}_{a, d}\right) f_{a, d}^{2}(\ln \Psi) d \ln \Psi
\end{aligned}
$$

where $\mathrm{g}($.$) is \epsilon \sim N\left(0, \Sigma^{\epsilon}\right), f_{a, d}^{1}(\ln \Psi)=N\left(\mu_{a, d}^{1}, \Sigma_{a, d}^{1}\right), f_{a, d}^{2}(\ln \Psi)=N\left(\mu_{a, d}^{2}, \Sigma_{a, d}^{2}\right)$

\subsection{3}

\section{Endogeneity of parental investment in our production function}

Endogeneity of parental investments result in the error term of production function no longer being independent from parental investment, that is we have $E\left(u_{t_{1}} \mid \theta_{t_{0}}, \boldsymbol{\Omega}, i_{t_{1}}, \boldsymbol{X}_{t_{1}}\right) \neq 0$. We solve this problem with the introduction of a control function for investment. We assume that the conditional expectation of the error term in equation (3-1), $u_{t_{1}}$, is linear on an endogeneity component $v_{t_{1}}$, and a true random error ${ }^{17}$. Hence, we have $E\left(u_{t_{1}} \mid \theta_{t_{0}}, \Omega, i_{t_{1}}, \boldsymbol{X}_{t_{1}}\right)=E\left(u_{t_{1}} \mid v_{t_{1}}\right)=\rho^{a, d} v_{t_{1}}$, and the error of the production function becomes:

$$
u_{t_{1}}=\rho^{a, d} v_{t_{1}}+\zeta_{i, t_{1}}
$$

We proceed to estimate the endogeneity component $v_{t_{1}}$, by constructing an equation with the determinants of the our endogenous variable, investment. We assume the equation on the determinants of investments is as follows:

$$
\ln i_{t_{1}}=\alpha_{1}^{a, d}+\alpha_{2}^{a, d} \ln \theta_{0}+\alpha_{3}^{a, d} \boldsymbol{\Omega}+\alpha_{4}^{a, d} \boldsymbol{X}_{t_{1}}+\alpha_{5}^{a, d} \ln q_{t_{1}}+v_{t_{1}}
$$

where, as standard, we assume that $E\left(v_{t_{1}} \mid \ln \theta_{t_{0}}, \ln \Omega, \boldsymbol{X}_{t_{1}}, \ln q_{t_{1}}\right)=0$. The investment equation contains all variables of the production function in addition to an instrument, $\ln q_{t_{1}}$. Our identification rests on finding a variable that affects ability only via parental investments. A natural candidate for our instruments are prices or income shocks. They are likely to affect investment through the family budget constraint, but not the production function directly. Here, we use the international monthly price of copper, which can be seen as

${ }^{17} \mathrm{We}$ also assume that both errors, $u_{t_{1}}$ and $v_{t_{1}}$, are jointly independent of the state variables $\theta_{t_{0}}, \boldsymbol{\Omega}, \boldsymbol{X}_{t_{1}}$, and that the parental investment has a one-to-one function with the endogenous error term, as in (47) 
a relevant exogenous shock on family income because of the importance of copper in Chilean economy. We use the average price over the last year of life of the child as our instrument. The relationship between copper price and investment can be either negative or positive. On one hand, as copper price rises the opportunity cost of not working becomes higher. This means parents would spend less time at home with their children. Further, higher salaries allows parents to hire alternative care for their children. On the other hand, income effect means that parents can consume more time with their children. In both cases, copper prices will affect child development through parental time investments.

Once we secure our identification, we use the investment equation to obtain an estimate of $\hat{v}_{t_{1}}^{a, d}$. This estimated error term becomes an additional variable in our production function, a variable that controls for the endogeneity of investment.

\subsubsection{1}

\section{Estimation Procedure}

We have now established our complete estimation approach. For clarity we detail each step of our estimation procedure.

In the first step, we estimate the distribution of demeaned measurements for pre and post ChCC cohorts and each age group. We assume $f\left(\tilde{m}_{a, d}\right)$ is a mixture of normal distributions given by the equation (??). We use an Expectation Maximisation algorithm ${ }^{18}$ to estimate the means and variancecovariance matrices of $f\left(\tilde{m}_{a, d}\right): \tilde{\mu}_{a, d}^{1}, \tilde{\Sigma}_{a, d}^{1}, \tilde{\mu}_{a, d}^{2}, \tilde{\Sigma}_{a, d}^{2}, \tilde{\tau}_{a, d}$.

In the next step, we estimate the distribution of latent variables $f_{a, d}(\ln \Psi)$, which is defined by the means and covariance-variance matrices of each mixture component, given by $\mu_{a, d}^{1}, \Sigma_{a, d}^{1}, \mu_{a, d}^{2}, \Sigma_{a, d}^{2}, \tau_{a, d}$, factor loadings matrix $\Lambda$ and the covariance matrix of the distribution of errors $\Sigma^{\epsilon}$. Note that the latter two are assumed to be the same between pre and post ChCC cohorts so that all differences between cohorts arise from differences in the distribution of latent variables.

The parameters of the latent variables are given by the minimum distance between the right handside of the equation and the parameters of the distribution of measurements, obtained in the earlier step, in the left handside

${ }^{18}$ This method has been widely utilised for estimating mixture of normals, as described in (48). This method consists of two steps. First, the expectation step computes the probability that each observation belongs to one of the normal distributions. Given these probabilities, we maximize the likelihood function in the second step. This two steps are repeated until convergence. 
of the system below ${ }^{19}$.

$$
\begin{gathered}
\tau_{a, d}=E\left[\tilde{\tau}_{a, d}\right] \\
\Lambda \mu_{a, d}^{1}=E\left[\tilde{\mu}_{a, d}^{1}\right] \\
\Lambda \mu_{a, d}^{2}=E\left[\tilde{\mu}_{a, d}^{2}\right] \\
\Lambda^{\prime} \Sigma_{a, d}^{1} \Lambda+\Sigma^{\epsilon}=E\left[\tilde{\Sigma}_{a, d}^{1}\right] \\
\Lambda^{\prime} \Sigma_{a, d}^{2} \Lambda+\Sigma^{\epsilon}=E\left[\tilde{\Sigma}_{a, d}^{2}\right]
\end{gathered}
$$

The final step consists of using $f_{a, d}(\ln \Psi)$ to draw a synthetic dataset of latent factors and estimate our production, equation (3-1), as if the latent variables were observable. Specifically we use OLS to estimate the determinants of investment, equation (3.4.3), and construct $\hat{v}_{t_{1}}$. Then we apply non-linear least squares with the addition of $\hat{v}_{t_{1}}$ and estimate parameters of our production function.

The standard errors are obtained using bootstrapp over all the procedure. We report confidence intervals for all our estimates. In this way, we don't need to assume a standard distribution to compute p-values for our estimates.

\section{5 \\ Results}

\subsection{1}

\section{System of measures and latent variables}

We begin by showing the measurements we chose for each of our latent variables. Our selection of measurements was guided by the literature on non-linear production function of abilities $(1,19,18,20)$ and the availabiltiy of measurement in our dataset. We have standard measurements of child's ability at birth, child's socio-emotional abilities and parental abilities. These measurements are derived from tests widely used in literature Wechsler Adult Intelligence Scale (WAIS) test-, mental health-CBCL test- and the big five personality test. However due to data restrictions, our cognitive ability consists of just one measurement per age gruop the psycho-motor Battelle score for ages 18-23 months and the Peabody Vocabulary tests for those of 3-4 years off age. Although these test are standard in the literature, other articles do

${ }^{19}$ The only conceptual difference between our estimation and (19) is that they compute the covariance matrix between latent traits and control by equating it to the covariance matrix between the measurement of the latent trait which had its weight normalised to one and the controls. We on the other hand, minimise the distance between the covariance matrix of latent traits and controls and the covariance matrices of all measurements and controls. Our estimation is computationally more demanding but more general. 
not use a sole test score to generate the child's cognitive ability. Our parental investments variable only reflects time investments in children. The standard in literature is to also use measurements which reflect material investments. Again, our data contains few variables of that nature ${ }^{20}$.

Table 3.6 shows the percentage of information of each measurement per latent variable for children aged 18-23 months, the first two columns, and for children aged 36-48 months, the last two columns. Analysing the table we note that at large information percentages remain constant across ages and across cohorts. Further, we note that the chosen measurements appear to have high levels of common correlation. The majority of measurements show percentages of signal to noise of at least one quarter.

For abilities at birth we have weight, height, and gestation length. The two first variables are the most informative with ratios of information higher than $60 \%$. We follow with the child's socio-emotional abilities, divided into externalising and internalising scores. Attentional problems have a lower percentage of information, which ranges from $30 \%$ to $47 \%$ and aggressive conduct has information percentages that vary from $63 \%$ to $94 \%$. While the poorest measurement on internalising has a signal ratio slightly above $20 \%$, the richest measurements has ratio of over $40 \%$.

Parental cognitive abilities, consists of four measurements, mother's and father's schooling in years and the mother's WAIS test score for vocabulary and memory. The least noisy measurements are mother education and father education, the former has ratios averaging $45 \%$ and the latter just below $35 \%$. Parental socio-emotional ability is measured using each dimension of the Big five personality test taken by the main carer. We see that the personality dimension with the highest commmunality is neuroticism while the dimesions of extroversion and kindness display the lowest communalities. We note however that the dimensions of the Big five personality test have low levels of communality in general at maximum of $35 \%$. Parental health is composed of mother's height and weight, all of which have similar levels of information.

Finally, parental investment contains variables on activities undertaken with child by the father and the mother during the week before the interview. These variables are given scores of 0-2 depending on whether neither, one or both parents undertook activity in question. For children of 48-36 months we have included in parental investment a variable reflecting the time spent in

\footnotetext{
${ }^{20}$ We have attempted to use the question "Do you have more than 10 children books at home?". However with this variable our E.M algorithm converged to a degenerate distribution. This is common with dummy variables with small variances. (48)
} 
nursery or day-care since completing 36 months $^{21}$. In table, 3.6 we observe differences in information percentages between ages. For younger children the most informative variables are activities related to reading books and singing to the child. For older children the reading books is accompanied by telling stories to the child.

Table 3.6: Percentage of information per measure of latent variables

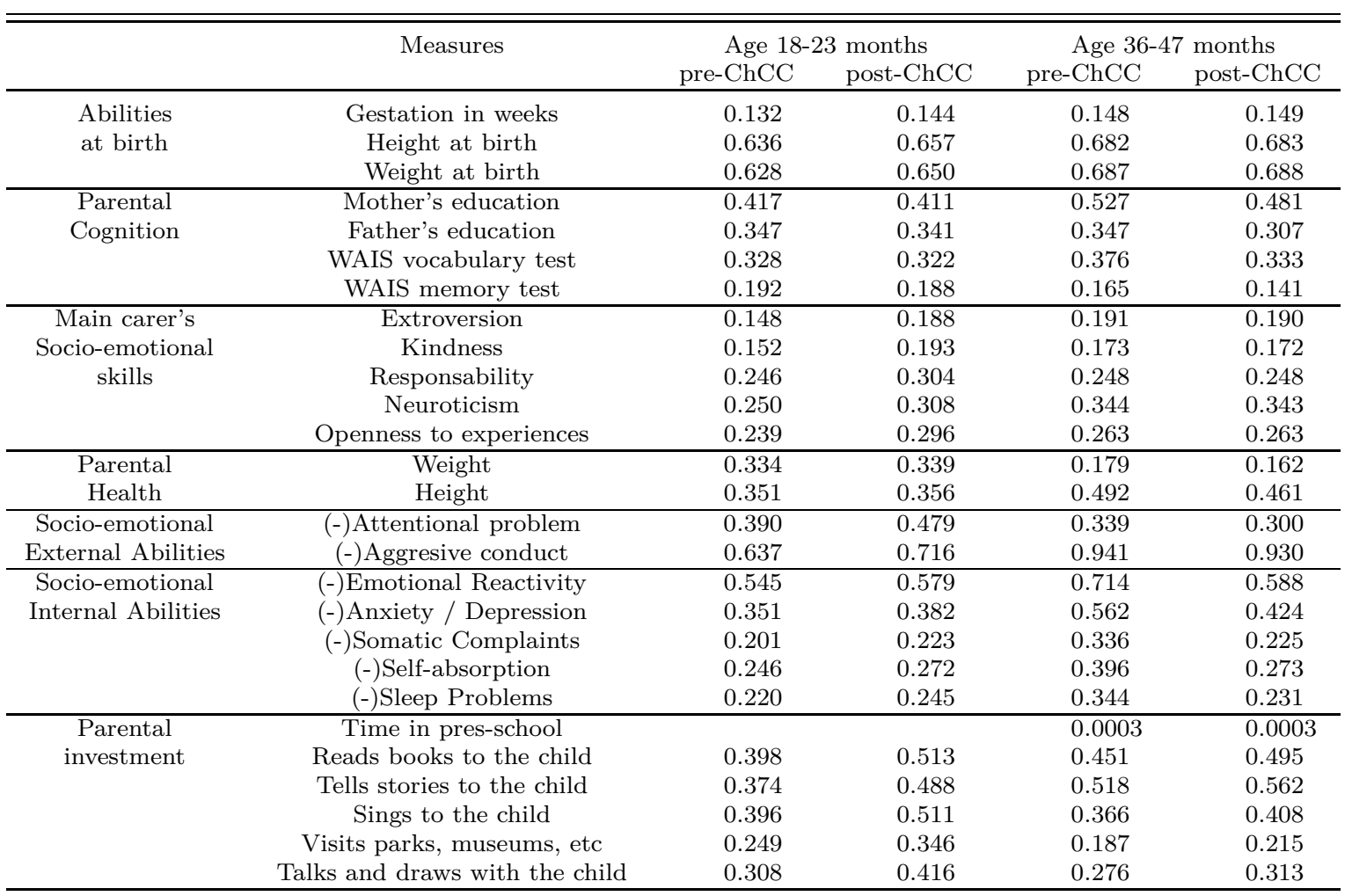

Source: Own elaboration based on EM estimation

We have established the composition of our latent variables. We can analise mean differences between pre and post ChCC cohorts. As discussed in the empirical strategy section, we have been most conservative, and thus attribute these differences to a lower bound of the effect of ChCC. For both age groups, we consistently observe that the post ChCC cohort has higher levels of external and internal socio-emotional skills when compared to the pre-ChCC cohort. The same is true for parental investment. On the other hand, parental socio-emotional skills remain unchanged after ChCC. For all other variables we have inconclusive results (See Table 3.7).

For cognition, our results are ambiguous. ChCC is associated with higher levels of cognitive skills for children of 18-23 months of age and lower levels of cognition for those of 36-47 months years of age. We note that the results

${ }^{21}$ We attempted to add the same variable for children aged 18 to 23 months. However, this variable was purely noise and few children attended daycare in that age. Thus, we decided to exclude it from our analysis. 
are not necessarily comparable between these two age groups as we use scores from different tests.

Table 3.7: Mean difference of latent variable before and after ChCC

\begin{tabular}{lcc}
\hline \hline & Age $18-23$ months & Age 36-47 months \\
& $(1)$ & $(2)$ \\
\hline External S.E. skills & 0.806 & 0.856 \\
& $(0.603,1.031)$ & $(0.715,0.995)$ \\
Internal S.E. skills & 0.303 & 0.252 \\
& $(0.247,0.392)$ & $(0.225,0.319)$ \\
Cognition & 0.910 & -0.310 \\
& $(0.818,1.113)$ & $(-0.443,-0.174)$ \\
Parental Investment & 0.369 & 0.368 \\
& $(0.253,0.532)$ & $(0.338,0.507)$ \\
Abilities at birth & 0.029 & -0.123 \\
& $(-0.092,0.135)$ & $(-0.186,-0.053)$ \\
Parental cognition & -0.024 & 0.042 \\
& $(-0.077,0.039)$ & $(0.013,0.069)$ \\
Parents' SE skills & -0.002 & -0.004 \\
& $(-0.076,0.078)$ & $(-0.038,0.038)$ \\
Parental health & 0.068 & 0.015 \\
& $(-0.022,0.171)$ & $(-0.084,0.092)$ \\
\hline \hline
\end{tabular}

\subsection{2}

\section{Production functions}

We can move to the estimation of the production functions. The first step in the estimation is to obtain $\hat{v}$ through modelling the determinants of investment. Table 3.8 contains the determinants of investment equation for age 18-23 months and 36-47 months. We see that the price of copper in the first year of life, first two columns, and in the third year of life, last two columns, is positively and significantly correlated with parental investment for both the cohort before and after the beginning of ChCC. The overall positive effect indicates that when parents become richer due to higher copper prices tend to spend more time with their children. Further, the confidence intervals of our coefficient estimates for before and after ChCC overlap for both ages. This suggests there is little differentiation between cohorts.

Our control variables affect the investment equation in a manner that is consistent with extant literature. Parental abilities are positively correlated with investment, especially cognitive abilities. An additional child in the household reduces parental investment, more so if this child is younger than 7 years of age. Parents who cohabit tend to invest more in their children. We however do not observe any correlations between abilities at birth and child sex with parental investment.

We begin by analysing general patterns in the production function of skills and health. First, all functions follow a Cobb-Douglas technology, which 
Table 3.8: Investment functions

\begin{tabular}{|c|c|c|c|c|}
\hline & \multicolumn{2}{|c|}{ Age $18-23$ months } & \multicolumn{2}{|c|}{ Age $36-47$ months } \\
\hline & $\begin{array}{c}\text { pre-ChCC } \\
(1) \\
\end{array}$ & $\begin{array}{c}\text { post-ChCC } \\
(2) \\
\end{array}$ & $\begin{array}{c}\text { pre-ChCC } \\
(3) \\
\end{array}$ & $\begin{array}{c}\text { post-ChCC } \\
(4) \\
\end{array}$ \\
\hline $\ln ($ Copper price $)$ & $\begin{array}{r}0.18 \\
(0.061,0\end{array}$ & $\begin{array}{r}0.1 \\
(0.086\end{array}$ & $\begin{array}{c}0.099 \\
(0.088,0.137)\end{array}$ & $\begin{array}{l}0.234 \\
54,0.481)\end{array}$ \\
\hline Ability at birth & $\begin{array}{c}-0.090 \\
(-0.162,-0.019)\end{array}$ & $\begin{array}{r}-0.0 \\
(-0.069\end{array}$ & $\begin{array}{c}-0.017 \\
(-0.048,0.018)\end{array}$ & $\begin{array}{r}0.0 \\
(-0.029\end{array}$ \\
\hline Parental Cognition & $\begin{array}{c}0.271 \\
(0.134,0.367)\end{array}$ & $\begin{array}{r}0.2 \\
(0.089\end{array}$ & $\begin{array}{c}0.208 \\
(0.145,0.285)\end{array}$ & $\begin{array}{r}0.2 \\
(0.211\end{array}$ \\
\hline Parental Health & $\begin{array}{c}0.134 \\
(0.053,0.266)\end{array}$ & $\begin{array}{r}0 . \\
(-0.03\end{array}$ & $\begin{array}{c}0.038 \\
(0.002,0.090)\end{array}$ & $\begin{array}{c}-0.071 \\
(-0.149,-0.013)\end{array}$ \\
\hline Parent's SE skills & $\begin{array}{c}0.241 \\
(0.143,0.385)\end{array}$ & $\begin{array}{c}0.134 \\
(-0.024,0.277)\end{array}$ & $\begin{array}{c}0.120 \\
(0.080,0.180)\end{array}$ & $\begin{array}{c}0.061 \\
(-0.005,0.124)\end{array}$ \\
\hline Parents live together & $\begin{array}{c}0.217 \\
(0.174,0.270)\end{array}$ & $\begin{array}{c}0.309 \\
(0.255,0.380)\end{array}$ & $\begin{array}{c}0.192 \\
(0.180,0.241)\end{array}$ & $\begin{array}{c}0.237 \\
(0.210,0.308)\end{array}$ \\
\hline Child is male & $\begin{array}{c}-0.021 \\
(-0.072,0.024)\end{array}$ & $\begin{array}{c}-0.105 \\
(-0.168,-0.029)\end{array}$ & $\begin{array}{c}-0.008 \\
(-0.031,0.010)\end{array}$ & $\begin{array}{c}-0.0004 \\
(-0.023,0.027)\end{array}$ \\
\hline Minors $<7$ at home & $\begin{array}{c}-0.087 \\
(-0.130,-0.032)\end{array}$ & $\begin{array}{c}0.017 \\
(-0.039,0.076)\end{array}$ & $\begin{array}{c}-0.020 \\
(-0.042,-0.003)\end{array}$ & $\begin{array}{c}-0.014 \\
(-0.053,0.013)\end{array}$ \\
\hline Minors $<18$ at home & $\begin{array}{c}0.017 \\
(-0.040,0.078)\end{array}$ & $\begin{array}{c}-0.005 \\
(-0.092,0.066)\end{array}$ & $\begin{array}{c}-0.035 \\
(-0.059,-0.018)\end{array}$ & $\begin{array}{c}-0.041 \\
(-0.071,-0.012)\end{array}$ \\
\hline Mother's Age & $\begin{array}{c}-0.067 \\
(-0.110,-0.020)\end{array}$ & $\begin{array}{c}-0.080 \\
(-0.131,-0.026)\end{array}$ & $\begin{array}{c}-0.021 \\
(-0.043,-0.005)\end{array}$ & $\begin{array}{c}-0.007 \\
(-0.040,0.020)\end{array}$ \\
\hline
\end{tabular}

Note: $90 \%$ bootstrapped confidence interval in parenthesis. 100 replications.

means that the inputs of the function are complements. This is evident as the substitution parameters confidence intervals contain zeros in all cases, as shown in tables 3.9 to 3.11. Secondly, the investment residuals are significant and negative in all cases but for the production of cognition of age 36-47 months in the pre-ChCC cohort. We interpret this as evidence that parents compensate shocks to the children's skills. Our results are consistent across the literature on non-linear production functions of child abilities(1, 19, 18, 20). In general, the share of parental investment is positive, significant and it increases after ChCC implementation. We see a positive and significant association between abilities at birth for health and cognition only. Finally, we observe that the inputs with the highest shares are parental investment and the dimension of parental ability that reflects the child's ability output.

Table 3.9 contains the estimated parameters of the external socioemotional skills production function for ages 18-23 months and 36-47 months. Results show that parental investment and parental socio-emotional skills are the only two statistically significant inputs for the production of socioemotional skills. As mentioned before, the share of parental investment raises for the post-ChCC cohorts. The relative change of this share is higher for children aged 37 to 48 months. Thus, the share of parental investment increases 
by $45 \%$ for the age group of $18-23$ months, whereas it increases by $84 \%$ for the older age group. In order to compensate the rise of this share, the share of parental socio-emotional skills falls. Nonetheless, it remains positive and significant for both age groups.

Parental investment, cognition and socio-emotional skills are the three highest shares of the production function of internal socio-emotional skills, as we can see in table 3.10. Contrary to external socio-emotional skills results, the relative increase of the investment share after ChCC implementation is higher for the younger age group, whose share rises by $71 \%, 50$ percent points higher than the increase of the older age group. The increase in the investment share is followed by a reduction in the shares of parental cognition and socioemotional skills. The former becomes non-significant for age 18-23 months, while the latter remains positive and significant for both age groups, like in the external socio-emotional production function.

Table 3.11 offers the parameters of our production function of cognitive abilities for ages 18-23 months and 36-48 months. For age 18-36 months we have that for both those conceived before and after January 2008 parental investment has highest coefficient of share. In the cohort before $\mathrm{ChCC}$, we have that parental investment has the highest share followed by parental cognition, socio-emotional skills, abilities at birth and health which is not significant. For the ChCC cohort, we have a case where the coefficient on investment is higher than one, and all other coefficients are either zero or negative. For age 36-48 months we have that parental cognition is the dominant input for both cohorts. Specifically, for the pre-ChCC cohort, only parental cognition and abilities at birth have non-zero coefficients. In the case of the post-ChCC cohort the variables which have significant impacts are parental investments and parental cognition. 
Table 3.9: External Socio-emotional skills

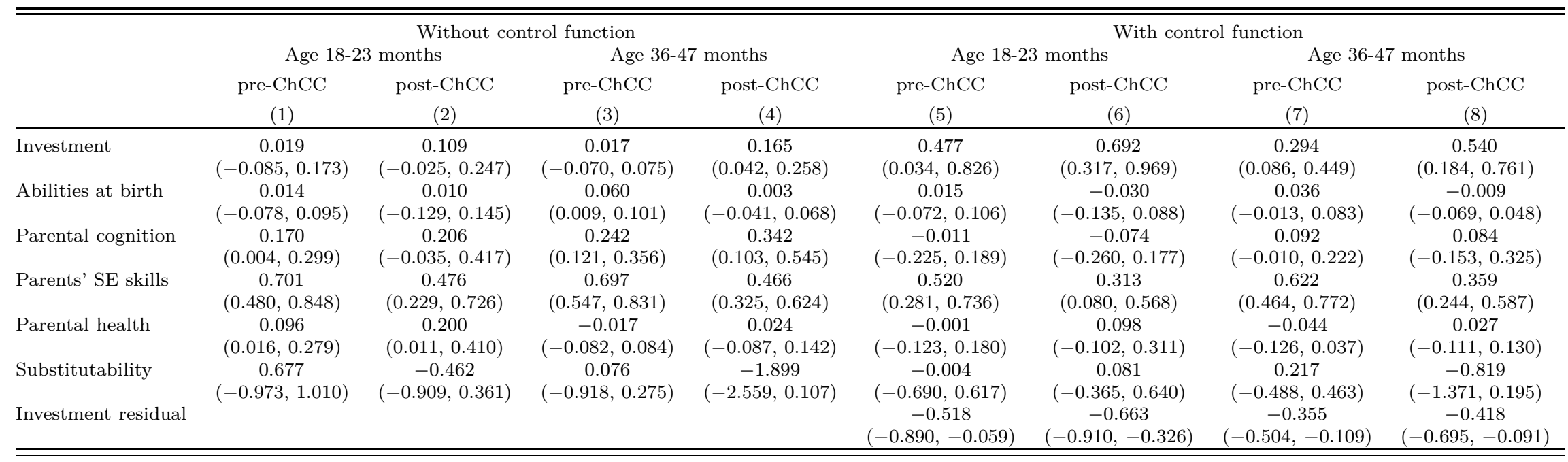

Note: $90 \%$ bootstrapped confidence interval in parenthesis. 100 replications. 
Table 3.10: Internal Socio-emotional skills

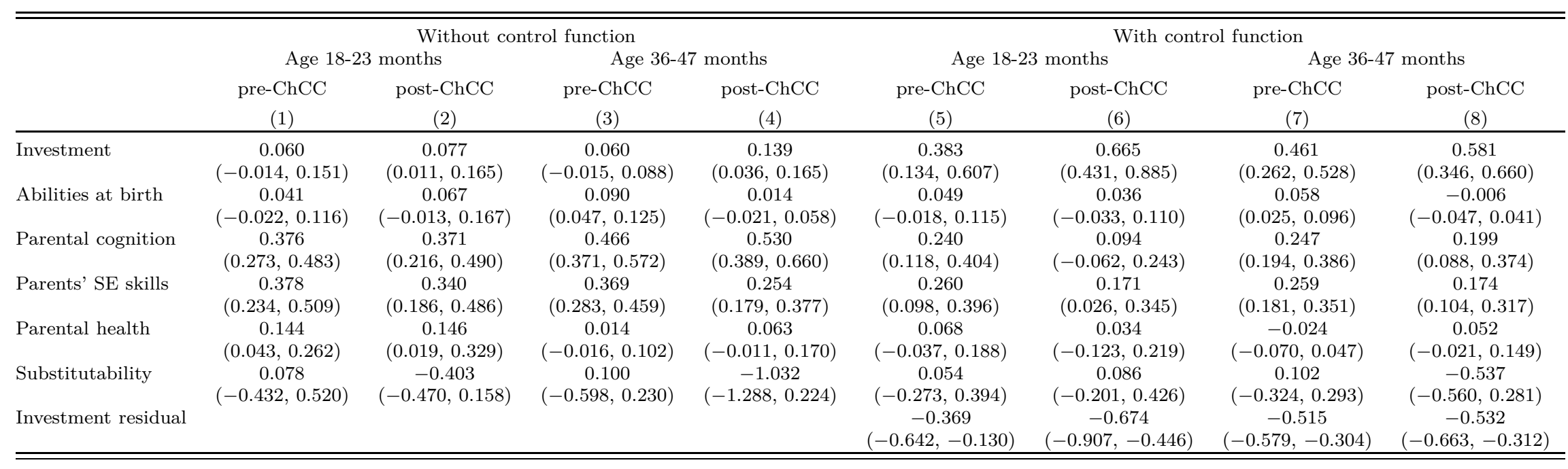

Note: $90 \%$ bootstrapped confidence interval in parenthesis. 100 replications. 
Table 3.11: Cognitive skills

\begin{tabular}{|c|c|c|c|c|c|c|c|c|}
\hline & \multicolumn{4}{|c|}{ Without control function } & \multicolumn{4}{|c|}{ With control function } \\
\hline & \multicolumn{2}{|c|}{ Age $18-23$ months } & \multicolumn{2}{|c|}{ Age $36-47$ months } & \multicolumn{2}{|c|}{ Age $18-23$ months } & \multicolumn{2}{|c|}{ Age 36-47 months } \\
\hline & $\begin{array}{c}\text { pre-ChCC } \\
(1) \\
\end{array}$ & $\begin{array}{c}\text { post-ChCC } \\
(2) \\
\end{array}$ & $\begin{array}{c}\text { pre-ChCC } \\
(3) \\
\end{array}$ & $\begin{array}{c}\text { post-ChCC } \\
(4) \\
\end{array}$ & $\begin{array}{c}\text { pre-ChCC } \\
(5) \\
\end{array}$ & $\begin{array}{c}\text { post-ChCC } \\
(6) \\
\end{array}$ & $\begin{array}{c}\text { pre-ChCC } \\
(7) \\
\end{array}$ & $\begin{array}{c}\text { post-ChCC } \\
(8) \\
\end{array}$ \\
\hline Investment & $\begin{array}{c}0.074 \\
(-0.034,0.204)\end{array}$ & $\begin{array}{c}0.185 \\
(0.109,0.248)\end{array}$ & $\begin{array}{c}0.049 \\
(-0.019,0.109)\end{array}$ & $\begin{array}{c}0.181 \\
(0.080,0.243)\end{array}$ & $\begin{array}{c}0.302 \\
(-0.013,0.641)\end{array}$ & $\begin{array}{c}1.550 \\
(1.146,1.959)\end{array}$ & $\begin{array}{c}-0.122 \\
(-0.299,0.030)\end{array}$ & $\begin{array}{c}0.284 \\
(0.098,0.420)\end{array}$ \\
\hline Abilities at birth & $\begin{array}{c}0.096 \\
(-0.002,0.181)\end{array}$ & $\begin{array}{c}0.131 \\
(0.028,0.196)\end{array}$ & $\begin{array}{c}0.065 \\
(0.018,0.121)\end{array}$ & $\begin{array}{c}0.034 \\
(-0.043,0.117)\end{array}$ & $\begin{array}{c}0.104 \\
(0.009,0.189)\end{array}$ & $\begin{array}{c}0.037 \\
(-0.099,0.134)\end{array}$ & $\begin{array}{c}0.074 \\
(0.026,0.131)\end{array}$ & $\begin{array}{c}0.027 \\
(-0.049,0.112)\end{array}$ \\
\hline Parental cognition & $\begin{array}{c}0.356 \\
(0.137,0.557)\end{array}$ & $\begin{array}{c}0.238 \\
(0.025,0.406)\end{array}$ & $\begin{array}{c}0.959 \\
(0.860,1.064)\end{array}$ & $\begin{array}{c}0.788 \\
(0.664,0.949)\end{array}$ & $\begin{array}{c}0.258 \\
(0.044,0.470)\end{array}$ & $\begin{array}{c}-0.418 \\
(-0.723,-0.114)\end{array}$ & $\begin{array}{c}1.054 \\
(0.930,1.208)\end{array}$ & $\begin{array}{c}0.713 \\
(0.552,0.902)\end{array}$ \\
\hline Parents' SE skills & $\begin{array}{c}0.367 \\
(0.199,0.541)\end{array}$ & $\begin{array}{c}0.430 \\
(0.249,0.600)\end{array}$ & $\begin{array}{c}-0.033 \\
(-0.121,0.050)\end{array}$ & $\begin{array}{c}-0.050 \\
(-0.164,0.052)\end{array}$ & $\begin{array}{c}0.283 \\
(0.081,0.520)\end{array}$ & $\begin{array}{c}0.050 \\
(-0.180,0.310)\end{array}$ & $\begin{array}{c}0.014 \\
(-0.074,0.100)\end{array}$ & $\begin{array}{c}-0.069 \\
(-0.180,0.029)\end{array}$ \\
\hline Parental health & $\begin{array}{c}0.107 \\
(0.005,0.286)\end{array}$ & $\begin{array}{c}0.015 \\
(-0.089,0.229)\end{array}$ & $\begin{array}{c}-0.040 \\
(-0.122,0.030)\end{array}$ & $\begin{array}{c}0.046 \\
(-0.045,0.155)\end{array}$ & $\begin{array}{c}0.054 \\
(-0.098,0.216)\end{array}$ & $\begin{array}{c}-0.219 \\
(-0.458,-0.019)\end{array}$ & $\begin{array}{c}-0.021 \\
(-0.098,0.064)\end{array}$ & $\begin{array}{c}0.045 \\
(-0.043,0.149)\end{array}$ \\
\hline Substitutability & $\begin{array}{c}0.589 \\
(-0.459,0.945)\end{array}$ & $\begin{array}{c}-0.111 \\
(-0.248,0.640)\end{array}$ & $\begin{array}{c}0.074 \\
(-0.122,0.547)\end{array}$ & $\begin{array}{c}-0.365 \\
(-0.530,0.222)\end{array}$ & $\begin{array}{c}0.448 \\
(-0.400,0.780)\end{array}$ & $\begin{array}{c}-0.098 \\
(-0.274,0.044)\end{array}$ & $\begin{array}{c}0.279 \\
(-0.028,0.614)\end{array}$ & $\begin{array}{c}-0.306 \\
(-0.472,0.193)\end{array}$ \\
\hline Investment residual & & & & & $\begin{array}{c}-0.267 \\
(-0.653,0.081)\end{array}$ & $\begin{array}{c}-1.592 \\
(-1.956,-1.174) \\
\end{array}$ & $\begin{array}{c}0.220 \\
(0.040,0.409) \\
\end{array}$ & $\begin{array}{c}-0.129 \\
(-0.300,0.042) \\
\end{array}$ \\
\hline
\end{tabular}

Note: $90 \%$ bootstrapped confidence interval in parenthesis. 100 replications. 
As seen so far, there are two features that describe the changes in the production of skills associated with the exposure of ChCC since gestation. First, we observe a consistent increment in the share of parental investment, which may imply a rise in the return of that variable, measured by the average value of its marginal product. Second, we detect a small decrease in the substitutability parameter, that could translate into a change the elasticity of substitution of the production functions. Table 3.12 shows the pre-post-ChCC differences in the average marginal product of investment and the elasticity of substitution. Notice that in spite of the increase of the investment share, the average marginal product of investment increased significantly only for cognitive and socio-emotional skills of children aged 18 to 24 months. Further, none of the reductions in the elasticity of substitution is statistically significant.

Considering the results of table 3.7 and the last results, we can conclude that $\mathrm{ChCC}$ exposure affected the age groups differently. For the younger age group, $\mathrm{ChCC}$ is associated with both a positive change in the quantity of investment and its productivity, with statistically significant differences in socio-emotional and cognitive skills. On the other hand,for the older age group, we observe a positive difference in socio-emotional skills and an increase in the quantity of investment but with no difference in the productivity of investment.

Table 3.12: Differences in production functions parameters

\begin{tabular}{lcccc}
\hline \hline & \multicolumn{2}{c}{ Investment Marg. Product } & \multicolumn{2}{c}{ Elasticity of substitution } \\
& Age 18-23 months & Age 36-47 months & Age 18-23 months & Age 36-47 months \\
& $(1)$ & $(2)$ & $(3)$ & $(4)$ \\
\hline External S.E. skills & 0.367 & 0.370 & 0.093 & -0.727 \\
& $(-0.083,0.765)$ & $(-0.043,0.620)$ & $(-1.075,2.150)$ & $(-1.185,0.148)$ \\
Internal S.E. skills & 0.355 & 0.154 & 0.038 & -0.463 \\
& $(0.069,0.591)$ & $(-0.027,0.260)$ & $(-0.665,0.732)$ & $(-0.601,0.321)$ \\
Cognition & 2.409 & 0.295 & -0.900 & -0.622 \\
& $(1.499,3.368)$ & $(0.142,0.410)$ & $(-1.699,0.260)$ & $(-1.522,0.103)$ \\
Health & -0.294 & 0.061 & -0.119 & -0.249 \\
& $(-0.675,0.029)$ & $(-0.118,0.284)$ & $(-0.348,0.298)$ & $(-0.412,0.051)$ \\
\hline \hline
\end{tabular}

Note: $90 \%$ bootstrapped confidence interval in parenthesis. 100 replications. 


\subsection{3}

\section{Model fit and simulation exercises}

We will now asses whether the model can explain observed differences in terms of latent skills between pre-ChCC and post-ChCC cohorts. We compare cohort differences in abilities as shown in our data and as predicted by the production function. Since these latent variables are also estimated we compare confidence intervals of our latent variables estimates and our model estimates. We check that the confidence intervals overlap for internal socio-emotional skills and cognition. For these variables our model is able to satisfactorily predict observed differences between cohorts. The same is not true for external socio-emotional skills, for which our model predicts only the sign of the difference but underestimates its magnitude. The parental socioemotional abilities are measured using a personality test that does not measure aggresive behavior and attentional problems, the components of externalising score. Hence, we cannot predict the variation in externalising abilities as well as in other latent traits.

Table 3.13: Observed and predicted value of children abilities - Age 18-23 months

\begin{tabular}{lcccc}
\hline \hline & \multicolumn{2}{c}{ Age 18-23 months } & \multicolumn{2}{c}{ Age 36-47 months } \\
& Observed & Predicted & Observed & Predicted \\
& $(1)$ & $(2)$ & $(3)$ & $(4)$ \\
\hline External S.E. skills & 0.806 & 0.376 & 0.856 & 0.431 \\
& $(0.603,1.031)$ & $(0.262,0.543)$ & $(0.715,0.995)$ & $(0.342,0.503)$ \\
Internal S.E. skills & 0.303 & 0.252 & 0.252 & 0.232 \\
& $(0.247,0.392)$ & $(0.202,0.331)$ & $(0.225,0.319)$ & $(0.199,0.277)$ \\
Cognition & 0.910 & 1.012 & -0.310 & -0.185 \\
& $(0.818,1.113)$ & $(0.901,1.113)$ & $(-0.443,-0.174)$ & $(-0.242,-0.123)$ \\
\hline \hline
\end{tabular}

Note: Bootstrapped confidence interval in brackets. 100 replications.

As ChCC contemplates a range of actions targeted at vulnerable children and families it is a natural step to analyse whether differences in child abilities associated with $\mathrm{ChCC}$ depend on family characteristics. We plot predicted differences between post-ChCC and pre-ChCC cohorts against deciles of parental cognition in figure 3.3.

For the 18-23 months age group, families with high level of cognition appear to have benefited the least from ChCC. In this group, the highest impacts are found for families in the middle of the distribution when considering effects on a child's socio-emotional abilities and for families at bottom of the distribution when considering impacts on a child's cognitive abilities. The story reverses once we look at the children of 36-47 months of age: the programme's effects appears to increase with parental cognition ${ }^{22}$.

\footnotetext{
${ }^{22}$ Here the exception is child's cognition for which the programme is associated with
} 
Figure 3.3: ChCC predicted effect along parental cognition distribution
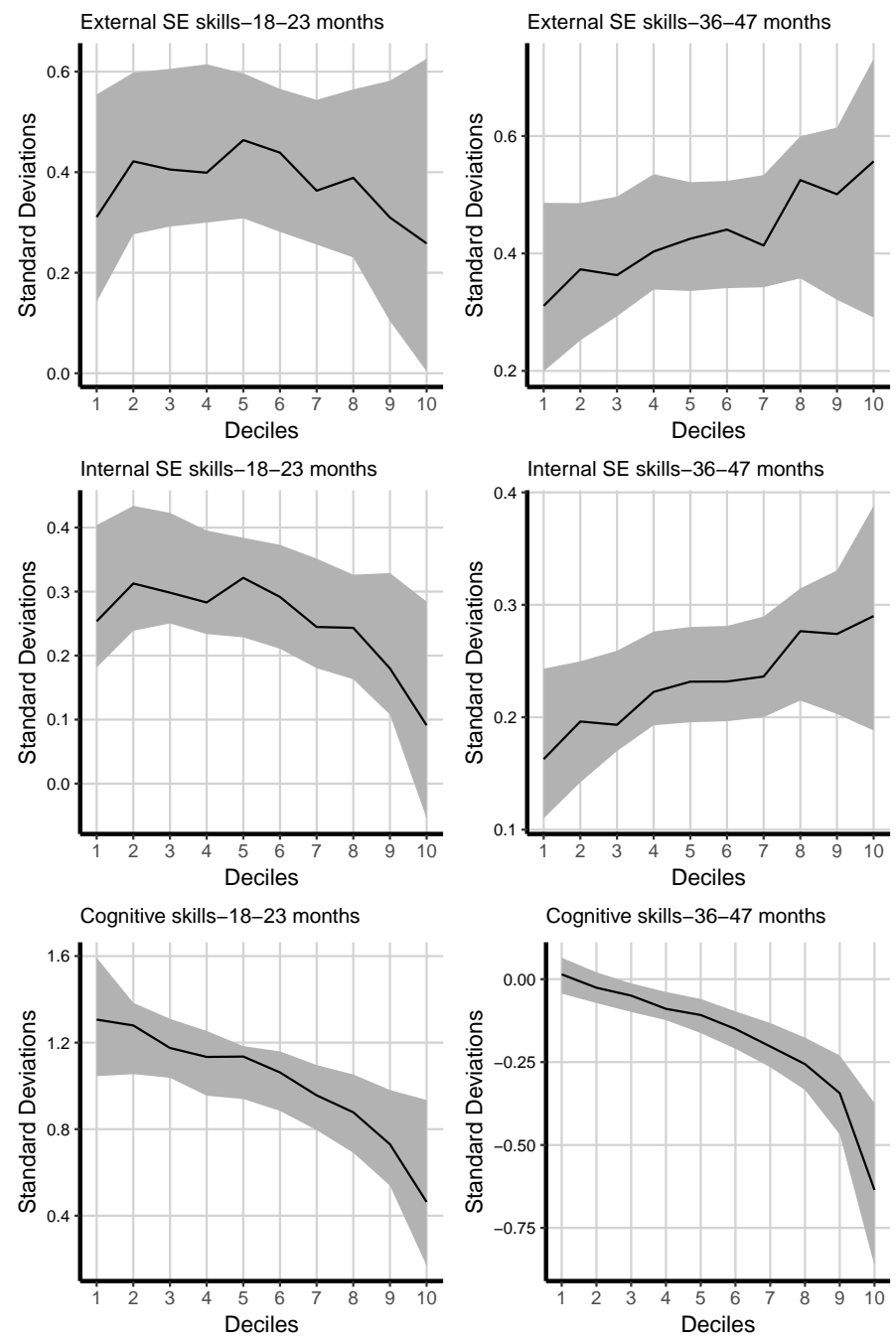

Source: Own elaboration based on production function results

As we have shown before, the technology of skill production and the quantity of inputs - essentially the investment level - change after the implementation of ChCC. We attempt to separate the part of ChCC effect associated with changes in the input levels from the total effect of ChCC, which also includes changes in the technology of skill production. In order to do that, we estimate differences between the pre and post $\mathrm{ChCC}$ cohorts fixing the production function parameters at the pre-ChCC levels. We call this statistic the Quantity effect. The results are in Table 3.14. Changes in the technology of production function explains between $80 \%-40 \%$ of the average effect of ChCC on socio-emotional abilities. For cognitive abilities, in age 18-23 months all the effect appears from differences in technology of production while for the 36-47 months age group all the negative impact also arises almost exclusively due to changes in technology.

negative effects and these effects are less negative for families with lowest levels of cognition 
Table 3.14: ChCC effect on children abilities with and without a change in production function

\begin{tabular}{lcccc}
\hline \hline & \multicolumn{2}{c}{ Age 18-23 months } & \multicolumn{2}{c}{ Age 36-47 months } \\
& Total effect & Quantity effect & Total effect & Quantity effect \\
& $(1)$ & $(2)$ & $(3)$ & $(4)$ \\
\hline External S.E. skills & 0.376 & 0.098 & 0.431 & 0.075 \\
& $(0.262,0.543)$ & $(0.023,0.227)$ & $(0.342,0.503)$ & $(0.016,0.143)$ \\
Internal S.E. skills & 0.252 & 0.085 & 0.232 & 0.134 \\
& $(0.202,0.331)$ & $(0.029,0.172)$ & $(0.199,0.277)$ & $(0.080,0.171)$ \\
Cognition & 1.012 & 0.059 & -0.185 & 0.003 \\
& $(0.901,1.113)$ & $(-0.018,0.151)$ & $(-0.242,-0.123)$ & $(-0.060,0.064)$ \\
\hline \hline
\end{tabular}

Note: Bootstrapped confidence interval in brackets. 100 replications.

Figure 3.4 shows ratio of quatity to total effect, as defined above per decile of parental cognition. The patterns for the younger age group shows that the percentage of total explained by level of parental investment decreases with parental ability decile. For those in the lower ability deciles the policy affected levels of investments while for those at the top of the ability decile the policy appears to have affected only the productivity of that investment. For the older age group we are not able to identify a clear pattern.

\section{6}

\section{conclusion}

This article offers a structural assessment of the national policy Chile Crece Contigo. We estimate a production function of children abilities and health for cohorts before and after the national expansion of ChCC. Our methodology allows us to separate the effects between changes in the magnitude of latent variables and changes in the parameters of the production function. The former are associated with changes in parental investment and child abilities while the latter is associated with changes in the productivity of inputs in our production function.

We find that families exposed to ChCC since gestation are characterised by higher levels of parent-child interaction and children with higher levels of socio-emotional abilities with an ambiguous result for children's cognitive abilities. In terms of productivity, we find gains in the productivity of investment associated with ChCC only for our young age groups. The policy emphasises the reduction of inequalities in the development of early-childhood within Chile by devising specific actions for vulnerable children and their families. Our results suggest that ChCC had its intended effects of higher impacts on vulnerable populations only for children up to two years old. For children of 3-4 years of age we find evidence of the opposite, least vulnerable families appear to benefit most from the policy. 
Figure 3.4: Proportion of ChCC quantity effect along parental cognition distribution
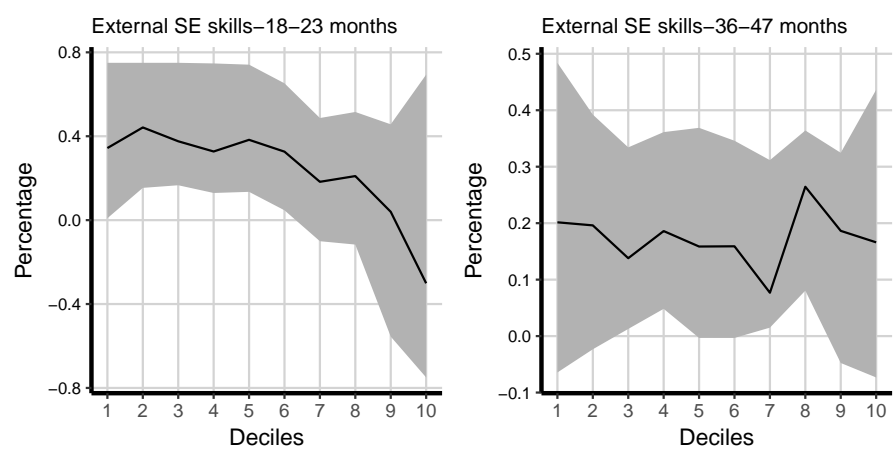

过
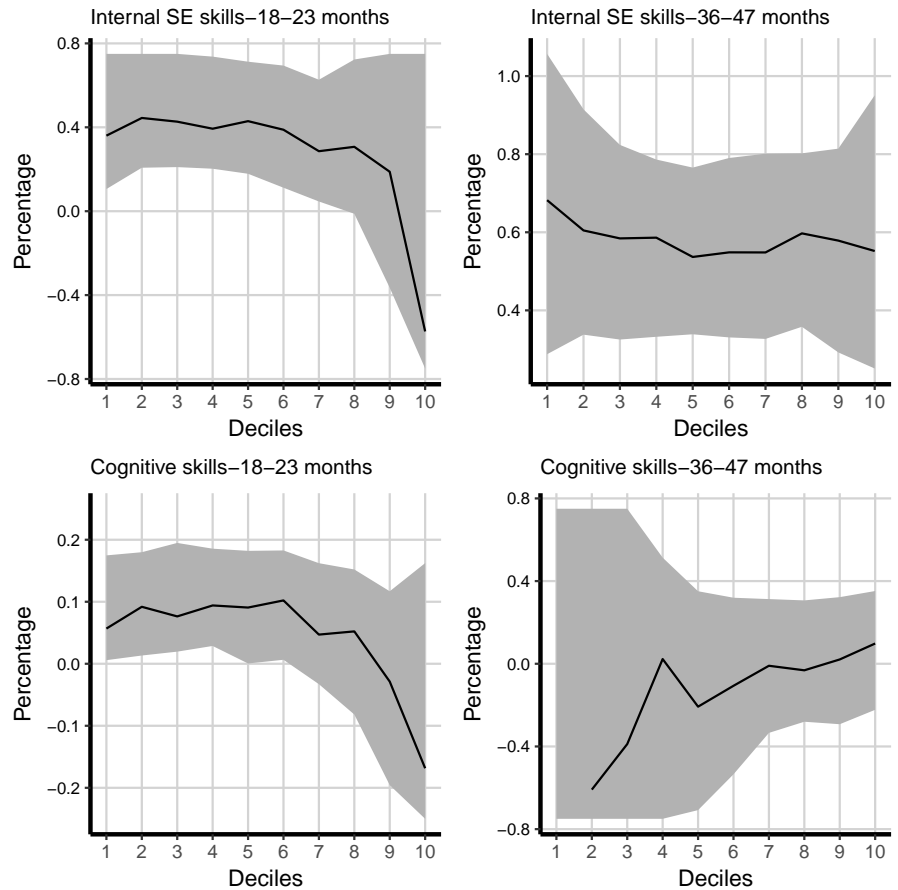

Source: Own elaboration based on production function results 


\section{Bibliography}

[1] CUNHA, F.; HECKMAN, J. J. ; SCHENNACH, S. M.. Estimating the technology of cognitive and noncognitive skill formation. Econometrica, 78(3):883-931, 2010.

[2] AGUIAR PALMA, M.; ROMAN EYZAGUIRRE, S.. An structural assessment of chile crece contigo. Unpublished manuscript, 2017.

[3] DUNCAN, G. J.; BROOKS-GUNN, J.. Consequences of growing up poor. Russell Sage Foundation, 1999.

[4] BROOKS-GUNN, J.; , G. J.. The effects of poverty on children. The future of children, p. 55-71, 1997.

[5] FLETCHER, J. M.; WOLFE, B. ; OTHERS. The importance of family income in the formation and evolution of non-cognitive skills in childhood. Centre for Economic Policy Research Discussion Paper Series, 665, 2012.

[7] SHEA, J.. Does parents' money matter? Journal of public Economics, 77(2):155-184, 2000.

[8] DAHL, G. B.; LOCHNER, L.. The impact of family income on child achievement: Evidence from the earned income tax credit. The American Economic Review, 102(5):1927-1956, 2012.

[9] DUNCAN, G. J.; , W. J.; BROOKS-GUNN, J. ; SMITH, J. R.. How much does childhood poverty affect the life chances of children? American sociological review, p. 406-423, 1998.

[10] HECKMAN, J. J.. Role of income and family influence on child outcomes. Annals of the New York Academy of Sciences, 1136(1):307-323, 2008.

[11] CARNEIRO, P.; HECKMAN, J. J.. The evidence on credit constraints in post-secondary schooling. Working Paper 9055, National Bureau of Economic Research, July 2002. 
[12] BELLEY, P.; LOCHNER, L.. The changing role of family income and ability in determining educational achievement. National Bureau of Economic Research, 2007.

[13] LOCHNER, L.; MONGE-NARANJO, A.. Credit constraints in education. Technical report, National Bureau of Economic Research, 2011.

[14] KEANE, M. P.; WOLPIN, K. I.. The career decisions of young men. Journal of political Economy, 105(3):473-522, 1997.

[15] CAUCUTT, E. M.; LOCHNER, L.. Early and late human capital investments, borrowing constraints, and the family. Technical report, National Bureau of Economic Research, 2012.

[16] Victora, C. G.; ARAúJo, C. L. P.; MENEZeS, A. M. B.; HALLAL, P. C.; VIEIRA, M. D. F.; NEUTZLING, M. B.; GONÇALVES, H.; VALLE, N. C.; LIMA, R. C.; ANSELMI, L. ; OTHERS. Methodological aspects of the 1993 pelotas (brazil) birth cohort study. Revista de saude publica, 40(1):39-46, 2006.

[17] HARPHAM, T.; HUTTLY, S.; WILSON, I. ; DE WET, T.. Linking public issues with private troubles: panel studies in developing countries. Journal of International Development, 15(3):353-363, 2003.

[18] ATTANASIO, O.; CATTAN, S.; FITZSIMONS, E.; MEGHIR, C. ; RUBIOCODINA, M.. Estimating the production function for human capital: Results from a randomized control trial in colombia. Technical report, National Bureau of Economic Research, 2015.

[19] ATTANASIO, O.; MEGHIR, C. ; NIX, E.. Human capital development and parental investment in india. Technical report, National Bureau of Economic Research, 2015.

[20] ATtANASIO, O.; MEGHIR, C.; NIX, E. ; SAlVATI, F.. Human capital growth and poverty: Evidence from ethiopia and peru. Review of Economic Dynamics, 25:234-259, 2017.

[21] LIU, J.. Childhood externalizing behavior: theory and implications. Journal of child and adolescent psychiatric nursing, 17(3):93-103, 2004.

[22] WILLCUTT, E. G.; DOYLE, A. E.; NIGG, J. T.; FARAONE, S. V. ; PENNINGTON, B. F.. Validity of the executive function theory of attentiondeficit/hyperactivity disorder: a meta-analytic review. Biological psychiatry, 57(11):1336-1346, 2005. 
[23] FORD, S.; FARAH, M. S.; SHERA, D. M. ; HURT, H.. Neurocognitive correlates of problem behavior in environmentally at-risk adolescents. Journal of Developmental \& Behavioral Pediatrics, 28(5):376-385, 2007.

[24] ANDERSON, P.. Assessment and development of executive function (ef) during childhood. Child neuropsychology, 8(2):71-82, 2002.

[25] BERNAL, R.; ATTANASIO, O.; PEÑA, X. ; VERA-HERNÁNDEZ, M.. Efectos de la Transición de Educación Inicial Comunitaria a Atención en Centros de Desarrollo Infantil en Colombia. DOCUMENTOS CEDE 014067, UNIVERSIDAD DE LOS ANDES-CEDE, Nov. 2015.

[26] WEILAND, C.; YOSHIKAWA, H.. Impacts of a prekindergarten program on children's mathematics, language, literacy, executive function, and emotional skills. Child Development, 84(6):2112-2130, 2013.

[27] WORLD HEALTH ORGANIZATION, W.; ORGANIZATION, W. H. ; OTHERS. A user's guide to the self reporting questionnaire (srq). Geneva: World Health Organization, p. 1-84, 1994.

[28] ATTANASIO, O. P.; FERNÁNDEZ, C.; FITZSIMONS, E. O.; GRANTHAMMCGREGOR, S. M.; MEGHIR, C. ; RUBIO-CODINA, M.. Using the infrastructure of a conditional cash transfer program to deliver a scalable integrated early child development program in colombia: cluster randomized controlled trial. BMJ, 349:g5785, 2014.

[29] YEUNG, W. J.; LINVER, M. R. ; BROOKS-GUNN, J.. How money matters for young children's development: Parental investment and family processes. Child development, 73(6):1861-1879, 2002.

[30] HECKMAN, J. J.. The economics, technology, and neuroscience of human capability formation. Proceedings of the national Academy of Sciences, 104(33):13250-13255, 2007.

[31] CUNHA, F.; HECKMAN, J.. The technology of skill formation. American Economic Review, 97(2):31-47, 2007.

[32] CUNHA, F.; HECKMAN, J. J.; LOCHNER, L. ; MASTEROV, D. V.. Interpreting the evidence on life cycle skill formation. Handbook of the Economics of Education, 1:697-812, 2006. 
[33] ATTANASIO, O. P.. The determinants of human capital formation during the early years of life: Theory, measurement, and policies. Journal of the European Economic Association, 13(6):949-997, 2015.

[34] WEIKART, D. P.; DELORIA, D. J.; LOWSER, S. A. ; WIEGERINK, R.. Longitudinal results of the ypsilanti perry preschool project. final report. volume ii of 2 volumes. 1970.

[35] HECKMAN, J. J.; MOON, S. H.; PINTO, R.; SAVELYEV, P. A. ; YAVITZ, A.. The rate of return to the highscope perry preschool program. Journal of public Economics, 94(1):114-128, 2010.

[36] WALKER, S. P.; CHANG, S. M.; POWELL, C. A. ; GRANTHAMMCGREGOR, S. M.. Effects of early childhood psychosocial stimulation and nutritional supplementation on cognition and education in growth-stunted jamaican children: prospective cohort study. The lancet, 366(9499):1804-1807, 2005.

[37] CAMPBElL, F. A.; RAMEY, C. T.; PUNGEllO, E.; SPARLING, J. ; MILLER-JOHNSON, S.. Early childhood education: Young adult outcomes from the abecedarian project. Applied developmental science, 6(1):42-57, 2002.

[39] FOX, S. E.; LEVITT, P. ; NELSON III, C. A.. How the timing and quality of early experiences influence the development of brain architecture. Child development, 81(1):28-40, 2010.

[40] GLUCKMAN, P.; HANSON, M.. Mismatch: Why our world no longer fits our bodies: Why our world no longer fits our bodies. OUP Oxford, 2006.

[41] SCHULZ, L. C.. The dutch hunger winter and the developmental origins of health and disease. Proceedings of the National Academy of Sciences, 107(39):16757-16758, 2010.

[42] SCHOLTE, R. S.; VAN DEN BERG, G. J. ; LINDEBOOM, M.. Longrun effects of gestation during the dutch hunger winter famine on labor market and hospitalization outcomes. Journal of health economics, 39:17-30, 2015.

[43] BLACK, S. E.; DeVEREUX, P. J. ; SALVANES, K. G.. From the cradle to the labor market? the effect of birth weight on adult outcomes. The Quarterly Journal of Economics, 122(1):409-439, 2007. 
[44] BIROLI, P.. Health and skill formation in early childhood. Unpublished manuscript, 2016.

[45] ALMOND, D.; CURRIE, J.. Killing me softly: The fetal origins hypothesis. The Journal of Economic Perspectives, 25(3):153-172, 2011.

[46] MENEZES-FILHO, N.. Minimum wages, early child development and human capital outcomes: Longitudinal evidence from brazil. Unpublished manuscript, 2016.

[47] WOOLDRIDGE, J. M.. Econometric analysis of cross section and panel data. MIT press, 2010.

[48] MCLACHLAN, G.; PEEL, D.. Finite mixture models. John Wiley \& Sons, 2004.

[49] MALUCCIO, J. A.; HODDINOTT, J.; BEHRMAN, J. R.; MARTORELL, R.; QUISUMBING, A. R. ; STEIN, A. D.. The impact of improving nutrition during early childhood on education among guatemalan adults. The Economic Journal, 119(537):734-763, 2009.

[50] BEDREGAL, P.. Chile crece contigo: el desafío de la protección social a la infancia. Report, Facultad de Medicina de la Pontifica Universidad Católica de Chile, November 2013.

[51] ASESORÍAS PARA EL DESARROLLO. Informe final de la evaluación de impacto del sistema de protección integral a la infancia (chile crece contigo, ccc). Articulos de la Dirección de Presupuesto Gobierno de Chile, 2013.

[52] SILVA, V.; MOLINA, H.. Cuatro años creciendo juntos: memoria de la instalación del sistema de protección integral a la infancia Chile Crece Contigo 2006-2010. Santiago: MIDEPLAN., 2010.

[54] MINISTERIO DE PLANIFICACION. Ley 20379 crea el sistema intersectorial de protecciǿn social e institucionaliza el subsistema de protecciǿn integral a la infancia "chile crece contigo", 2009.

[55] BedregAL, P.; TORRES, A. ; CARVAllO, C.. Chile crece contigo: el desafío de la protección social a la infancia. Working paper, UNDP Chile, December 2014.

[56] BEHRMAN, J.; BRAVO, D. ; URZÚA, S.. Encuesta longitudinal de la primera infancia: Aspectos metodológicos y primeros resultados. Report, Departamento de Economia Universidad de Chile, December 2010. 
[57] STRAIN, H.. Norma Tecnica para la supervision de niños y niñas de 0 a 9 años en la Atencion Primaria de Salud. Ministerio de Salud Chile, 2014.

[58] MORAGA, C.. Orientaciones tecnicas visita domiciliaria integral para el desarrollo biopsicosocial de la infancia. Technical report, Ministerio de Salud Chile, 2009.

[59] HERRERA, R.; LARRAÑAGA, O. ; TELIAS, A.. La ficha de protección social. Documento de Trabajo, 3, 2010.

[60] GLOVER, V.. Maternal depression, anxiety and stress during pregnancy and child outcome; what needs to be done. Best practice \& research Clinical obstetrics \& gynaecology, 28(1):25-35, 2014. 


\section{Chapter 1 - Additional results}

\section{A.1}

\section{A life-cycle model of human capital}

Here we detail a basic model of life-cycle behaviour of human capital. In our model an individual lives for four periods. The first three periods represent the individual's childhood, where he chooses how much to invest, save and consume given exogenous transfers from parents. The following period consists of adulthood. In period four, adulthood human capital is formed and grow as a combination of investments in childhood. In adulthood income is defined by level of human capital multiplied by market wages. The model is as follows:

$$
\operatorname{Max}_{c_{1}, \ldots, c_{7}} \sum_{j=1}^{4} \beta^{j-1} U\left(c_{j}\right)
$$

where $U^{\prime}(c)>0, U^{\prime \prime}(c)<0$, subject to

$$
\begin{gathered}
a_{1}=R a_{0}+y_{1}-i_{1}-c_{1} \\
a_{2}=R a_{1}+y_{2}-i_{2}-c_{2} \\
a_{3}=R a_{2}+y_{3}-i_{3}-c_{3} \\
c_{4}=R a_{3}+w f\left(i_{1}, i_{2}, i_{3}, \theta\right)
\end{gathered}
$$

Finally, we add limits on how much an individual can borrow during their childhood years. This reflects the fact that some families are restricted in the amount borrowing they can undertake to invest in their young.

$$
\begin{aligned}
& -a_{1} \leq L_{1} \\
& -a_{2} \leq L_{2} \\
& -a_{3} \leq L_{3}
\end{aligned}
$$

The next step is to set up a Lagrangean function to solve our model. We use $\lambda$ as multipliers for equality restrictions and $\mu$ as multipliers for inequality restrictions. The Kuhn Tucker conditions associated with our solutions are: 


$$
\begin{aligned}
& \frac{\partial L}{\partial i_{1}}=-\lambda_{1}^{*}+\lambda_{4}^{*} w f_{1}\left(i_{1}^{*}, i_{2}^{*}, i_{3}^{*}, \theta\right)=0 \\
& \frac{\partial L}{\partial i_{2}}=-\lambda_{2}^{*}+\lambda_{4}^{*} w f_{1}\left(i_{1}^{*}, i_{2}^{*}, i_{3}^{*}, \theta\right)=0 \\
& \frac{\partial L}{\partial i_{3}}=-\lambda_{3}^{*}+\lambda_{4}^{*} w f_{1}\left(i_{1}^{*}, i_{2}^{*}, i_{3}^{*}, \theta\right)=0 \\
& \frac{\partial L}{\partial c_{1}}=U^{\prime}\left(c_{1}^{*}\right)-\lambda_{1}^{*}=0 \\
& \frac{\partial L}{\partial c_{2}}=U^{\prime}\left(c_{2}^{*}\right)-\lambda_{2}^{*}=0 \\
& \frac{\partial L}{\partial c_{3}}=U^{\prime}\left(c_{3}^{*}\right)-\lambda_{3}^{*}=0 \\
& \frac{\partial L}{\partial c_{4}}=U^{\prime}\left(c_{4}^{*}\right)-\lambda_{4}^{*}=0 \\
& \frac{\partial L}{\partial a_{2}}=-\lambda_{1}^{*}+\lambda_{2}^{*} R+\mu_{1}^{*}=0 \\
& \frac{\partial L}{\partial a_{3}}=-\lambda_{2}^{*}+\lambda_{3}^{*} R+\mu_{2}^{*}=0 \\
& \frac{\partial L}{\partial a_{4}}=-\lambda_{3}^{*}+\lambda_{4}^{*} R+\mu_{3}^{*}=0 \\
& \frac{\partial L}{\partial \lambda_{1}}=a_{1}^{*}-R a_{0}-y_{1}+i_{1}^{*}+c_{1}^{*}=0 \\
& \frac{\partial L}{\partial \lambda_{2}}=a_{2}^{*}-R a_{1}^{*}-y_{2}+i_{2}^{*}+c_{2}^{*}=0 \\
& \frac{\partial L}{\partial \lambda_{3}}=a_{3}^{*}-R a_{2}^{*}-y_{3}+i_{3}^{*}+c_{3}^{*}=0 \\
& \frac{\partial L}{\partial \lambda_{4}}=-R a_{3}^{*}-w f\left(i_{1}^{*}, i_{2}^{*}, i_{3}^{*}, \theta\right)+c_{4}^{*}=0 \\
& \mu_{1}^{*}\left[-L_{1}-a_{1}^{*}\right]=0 \\
& \mu_{2}^{*}\left[-L_{2}-a_{2}^{*}\right]=0 \\
& \mu_{3}^{*}\left[-L_{3}-a_{3}^{*}\right]=0 \\
& -a_{1}^{*} \leq L_{1} \\
& -a_{2}^{*} \leq L_{2} \\
& -a_{3}^{*} \leq L_{3} \\
& \left(\mu_{1}^{*}, . ., \mu_{3}^{*} ; \lambda_{1}^{*}, \ldots, \lambda_{4}^{*}\right) \geq 0
\end{aligned}
$$

We begin with the simplest case where no households are credit constrained. We then have the case where our inequality restrictions do not bind. 
Using equations (15)-(16), we see that $\mu *_{1}=\mu_{2}^{*}=\mu_{3}^{*}=0$. Therefore, we can join (4)-(7) and (7)-(10), and we have:

$$
\frac{U^{\prime}\left(c_{j}^{*}\right)}{U^{\prime}\left(c_{j+1}^{*}\right)}=R \beta \quad \forall \quad j=1, \ldots, 3
$$

This equation determines consumption levels $c_{1}^{*}, \ldots, c_{3}^{*}$. Using equation (22) above, equations (1)-(3) become:

$$
\begin{aligned}
& f_{1}\left(i_{1}^{*}, i_{2}^{*}, i_{3}^{*}, \theta\right)=\frac{R^{3}}{w} \\
& f_{2}\left(i_{1}^{*}, i_{2}^{*}, i_{3}^{*}, \theta\right)=\frac{R^{2}}{w} \\
& f_{3}\left(i_{1}^{*}, i_{2}^{*}, i_{3}^{*}, \theta\right)=\frac{R}{w}
\end{aligned}
$$

The above system defines the optimum levels of investment in childhood development $i_{1}^{*}(\theta), i_{2}^{*}(\theta), i_{3}^{*}(\theta)$. We see that in the presence of perfect financial markets investment is independent of income levels.

We then proceed to find the unconstrained levels of savings $a_{2}^{*}, . . a_{3}^{*}$ and final consumption $c_{4}^{*}$ using the budget constraint equations (17)-(23). Finally the equality Lagrangean multipliers $\lambda_{1}^{*}, . . \lambda_{4}^{*}$ are given by inserting the optimum values of consumption in equations (4)-(10). Hence, we have now fully characterised our model when households are unrestricted.

The next step is to examine how our solutions change once we introduce borrowing constraints. We denote our restricted solution set with the superscript $r$.

Assume first that all restrictions hold with equality. Thus, $a_{1}^{r}=L_{1}$, $a_{2}^{r}=L_{2}, a_{3}^{r}=L_{3}$. This means $\left(\mu_{1}^{r}, . ., \mu_{3}^{r}\right) \geq 0$ in equations (8)-(10). We can then show that equation (26) transforms into the following inequality:

$$
\frac{U^{\prime}\left(c_{j}^{r}\right)}{U^{\prime}\left(c_{j+1}^{r}\right)} \geq R \beta \quad \forall \quad j=1, \ldots, 3
$$

As we assumed a strictly concave utility function the above implies that $\frac{c_{j}^{r}}{c_{j+1}^{r}} \leq \frac{c_{j}^{*}}{c_{j+1}^{*}}$. This means that due to credit constraints individuals will increase future consumption relatively to present consumption during childhood. The introduction of constraints will thus not allow perfect consumption smoothing and will be welfare lowering.

We compute the new equations defining the levels of investment, when all three constraints bind as:

$$
\begin{gathered}
f_{1}\left(i_{1}^{r}, i_{2}^{r}, i_{3}^{r}, \theta\right)=\frac{R^{3}}{w}\left[\frac{u^{\prime}\left(c_{3}^{r}\right)}{u^{\prime}\left(c_{3}^{r}\right)-\mu_{3}^{r}}\right]\left[\frac{u^{\prime}\left(c_{2}^{r}\right)}{u^{\prime}\left(c_{2}^{r}\right)-\mu_{2}^{r}}\right]\left[\frac{u^{\prime}\left(c_{1}^{r}\right)}{u^{\prime}\left(c_{1}^{r}\right)-\mu_{1}^{r}}\right] \\
f_{2}\left(i_{1}^{r}, i_{2}^{r}, i_{3}^{r}, \theta\right)=\frac{R^{2}}{w}\left[\frac{u^{\prime}\left(c_{3}^{r}\right)}{u^{\prime}\left(c_{3}^{r}\right)-\mu_{3}^{r}}\right]\left[\frac{u^{\prime}\left(c_{2}^{r}\right)}{u^{\prime}\left(c_{2}^{r}\right)-\mu_{2}^{r}}\right]
\end{gathered}
$$




$$
f_{3}\left(i_{1}^{r}, i_{2}^{r}, i_{3}^{r}, \theta\right)=\frac{R}{w}\left[\frac{u^{\prime}\left(c_{3}^{r}\right)}{u^{\prime}\left(c_{3}^{r}\right)-\mu_{3}^{r}}\right]
$$

Analysing the above equations we see that when all constraints bind $f_{3}\left(i_{1}^{r}, i_{2}^{r}, i_{3}^{r}, \theta\right) \leq f_{3}\left(i_{1}^{*}, i_{2}^{*}, i_{3}^{*}, \theta\right), f_{2}\left(i_{1}^{r}, i_{2}^{r}, i_{3}^{r}, \theta\right) \leq f_{2}\left(i_{1}^{*}, i_{2}^{*}, i_{3}^{*}, \theta\right)$, and $f_{1}\left(i_{1}^{r}, i_{2}^{r}, i_{3}^{r}, \theta\right) \leq f_{1}\left(i_{1}^{*}, i_{2}^{*}, i_{3}^{*}, \theta\right)$. The equations also make it intuitive to analyse the cases of only one or two constraints bind, we need only make the relevant Lagrange multiplier $\mu=0$.

In any case, the effect of credit constraints on investment levels will depend on the functional form chosen for human capital formation, particularly on the degree of substitutability between investments in different periods of childhood. 
Figure A.1: Real value of national minimum wage by date of birth

Real national minimum wage by date of birth

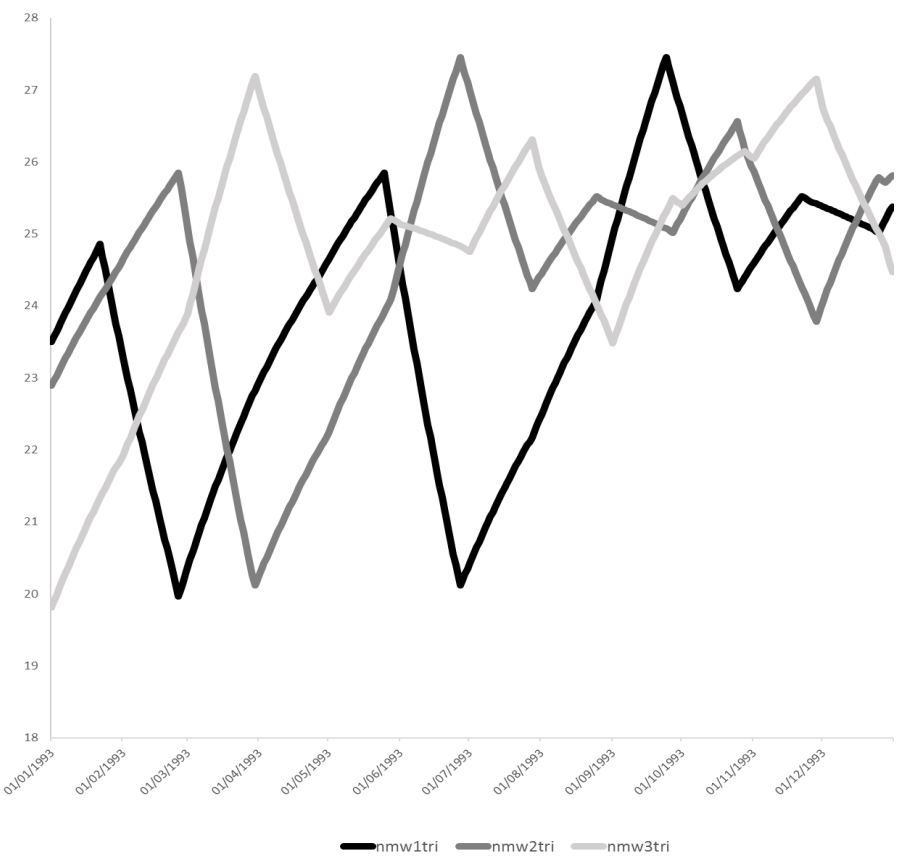

Source: Own elaboration based on IPEA data

Table A.1: Attrition

\begin{tabular}{lccc}
\hline & F-test & & \\
\hline VARIABLES & All 3 waves & Not in all 3 waves & P-Value \\
\hline Household income in m.s & 4.21 & 4.57 & 0.06 \\
Mother is white & 0.77 & 0.80 & 0.02 \\
Mother's age & 26.08 & 25.76 & 0.12 \\
Father's age & 29.65 & 29.24 & 0.11 \\
Male & 0.48 & 0.53 & 0.00 \\
Smoked during pregnancy & 0.33 & 0.34 & 0.46 \\
Drank alcohol during pregnancy & 0.05 & 0.05 & 0.45 \\
Pre-natal visits & 7.75 & 7.38 & 0.00 \\
Cesarian birth & 0.31 & 0.30 & 0.38 \\
Public Sector birth & 0.87 & 0.84 & 0.01 \\
Dubowitz Score of gestational age & 53.15 & 52.39 & 0.00 \\
High Blood Pressure in pregnancy & 0.16 & 0.16 & 0.88 \\
Diabetes in pregnancy & 0.02 & 0.02 & 0.61 \\
Weight at birth & 3.179 & 3.084 & 0.00 \\
Baby in ICU & 0.04 & 0.06 & 0.00 \\
\hline Number of children 1993 & 2.17 & 2.18 & 0.79 \\
\hline
\end{tabular}


Table A.2: Schooling at age 18

\begin{tabular}{|c|c|c|c|c|c|}
\hline VARIABLES & $\begin{array}{c}(1) \\
\text { Educ. }\end{array}$ & $\begin{array}{c}(2) \\
\text { Educ. }\end{array}$ & $\begin{array}{c}\text { (3) } \\
\text { Educ. }\end{array}$ & $\begin{array}{c}\text { (4) } \\
\text { Educ. }\end{array}$ & $\begin{array}{c}(5) \\
\text { Educ. }\end{array}$ \\
\hline Family income at birth in log & $\begin{array}{c}0.537^{* * * *} \\
(0.0411)\end{array}$ & $\begin{array}{c}0.465^{* * *} \\
(0.0396)\end{array}$ & $\begin{array}{c}0.255^{* * *} \\
(0.0428)\end{array}$ & $\begin{array}{c}0.169^{* * *} \\
(0.0364)\end{array}$ & $\begin{array}{c}0.153^{* * *} \\
(0.0370)\end{array}$ \\
\hline Family income at age 11 in log & $\begin{array}{c}0.510^{* * *} \\
(0.0453)\end{array}$ & $\begin{array}{c}0.442^{* * *} \\
(0.0425)\end{array}$ & $\begin{array}{c}0.204^{* * *} \\
(0.0433)\end{array}$ & $\begin{array}{c}0.135^{* * *} \\
(0.0385)\end{array}$ & $\begin{array}{c}0.112^{* * *} \\
(0.0389)\end{array}$ \\
\hline Family income at age 18 in log & $\begin{array}{c}0.262^{* * *} \\
(0.0391)\end{array}$ & $\begin{array}{c}0.307 * * * \\
(0.0368)\end{array}$ & $\begin{array}{c}0.250^{* * *} \\
(0.0359)\end{array}$ & $\begin{array}{c}0.128^{* * *} \\
(0.0312)\end{array}$ & $\begin{array}{c}0.133 * * * \\
(0.0315)\end{array}$ \\
\hline Male & & $\begin{array}{c}-0.919 * * * \\
(0.0644)\end{array}$ & $\begin{array}{c}-0.907^{* * *} \\
(0.0642)\end{array}$ & $\begin{array}{c}-0.532^{* * *} \\
(0.0567)\end{array}$ & $\begin{array}{c}-0.520 * * * \\
(0.0583)\end{array}$ \\
\hline Child is black or brown & & $\begin{array}{c}-0.506^{* * *} \\
(0.0756)\end{array}$ & $\begin{array}{c}-0.432^{* * *} \\
(0.0768)\end{array}$ & $\begin{array}{c}-0.247^{* * *} \\
(0.0676)\end{array}$ & $\begin{array}{c}-0.225^{* * *} \\
(0.0692)\end{array}$ \\
\hline Age in decimals 2004 & & $\begin{array}{c}0.0804 \\
(0.0985)\end{array}$ & $\begin{array}{c}0.152 \\
(0.0977)\end{array}$ & $\begin{array}{c}0.270^{* * *} \\
(0.0846)\end{array}$ & $\begin{array}{c}0.246^{* * *} \\
(0.0859)\end{array}$ \\
\hline Number of pregnancies 1993 & & $\begin{array}{c}-0.215^{* * *} \\
(0.0210)\end{array}$ & $\begin{array}{c}-0.156^{* * * *} \\
(0.0228)\end{array}$ & $\begin{array}{c}-0.0774^{* * *} \\
(0.0200)\end{array}$ & $\begin{array}{c}-0.0780 * * * \\
(0.0205)\end{array}$ \\
\hline Lives with husband or partner & & $\begin{array}{c}0.368^{* * *} \\
(0.111)\end{array}$ & $\begin{array}{c}0.333^{* * *} \\
(0.118)\end{array}$ & $\begin{array}{c}0.152 \\
(0.108)\end{array}$ & $\begin{array}{c}0.103 \\
(0.114)\end{array}$ \\
\hline Mother's education 1993 & & & $\begin{array}{c}0.105^{* * *} \\
(0.0125)\end{array}$ & $\begin{array}{c}0.0708^{* * *} \\
(0.0111)\end{array}$ & $\begin{array}{c}0.0714^{* * *} \\
(0.0112)\end{array}$ \\
\hline Father's education 1993 & & & $\begin{array}{c}0.0675 * * * \\
(0.0121)\end{array}$ & $\begin{array}{c}0.0507^{* * *} \\
(0.0107)\end{array}$ & $\begin{array}{c}0.0532^{* * *} \\
(0.0107)\end{array}$ \\
\hline Mother psychological index (SQR-20)(-) & & & $\begin{array}{c}0.205^{* * *} \\
(0.0386)\end{array}$ & $\begin{array}{c}0.0553 \\
(0.0358)\end{array}$ & $\begin{array}{l}0.0600^{*} \\
(0.0364)\end{array}$ \\
\hline Mother's social activity 2004 & & & $\begin{array}{l}0.00735 \\
(0.0129)\end{array}$ & $\begin{array}{l}0.00164 \\
(0.0114)\end{array}$ & $\begin{array}{c}-0.00273 \\
(0.0117)\end{array}$ \\
\hline Mother or father had emotional problems & & & $\begin{array}{c}-0.152^{* *} \\
(0.0774)\end{array}$ & $\begin{array}{l}-0.0831 \\
(0.0675)\end{array}$ & $\begin{array}{l}-0.0617 \\
(0.0687)\end{array}$ \\
\hline Mother's height z-score & & & $\begin{array}{c}0.0838^{* *} \\
(0.0354)\end{array}$ & $\begin{array}{c}0.0123 \\
(0.0327)\end{array}$ & $\begin{array}{c}0.0162 \\
(0.0332)\end{array}$ \\
\hline Mother's weight z-score & & & $\begin{array}{l}-0.0104 \\
(0.0360)\end{array}$ & $\begin{array}{l}-0.0412 \\
(0.0326)\end{array}$ & $\begin{array}{l}-0.0383 \\
(0.0328)\end{array}$ \\
\hline Hyperactivity Scale (-) & & & & $\begin{array}{c}0.255^{* * *} \\
(0.0347)\end{array}$ & $\begin{array}{c}0.244^{* * *} \\
(0.0355)\end{array}$ \\
\hline Conduct Problems Scale (-) & & & & $\begin{array}{c}0.196 * * * \\
(0.0391)\end{array}$ & $\begin{array}{c}0.170^{* * *} \\
(0.0403)\end{array}$ \\
\hline Difficulties at school (1-4) & & & & $\begin{array}{c}-0.0927^{* * *} \\
(0.0347)\end{array}$ & $\begin{array}{c}-0.0961^{* * *} \\
(0.0359)\end{array}$ \\
\hline Number of grade retentions & & & & $\begin{array}{c}-0.968 * * * \\
(0.0454)\end{array}$ & $\begin{array}{c}-0.937^{* * *} \\
(0.0470)\end{array}$ \\
\hline Emotional Problems Scale (-) & & & & $\begin{array}{c}-0.187^{* * *} \\
(0.0343)\end{array}$ & $\begin{array}{c}-0.176^{* * *} \\
(0.0344)\end{array}$ \\
\hline Peer Problems Scale (-) & & & & $\begin{array}{c}0.0842^{* *} \\
(0.0344)\end{array}$ & $\begin{array}{c}0.0803^{* *} \\
(0.0351)\end{array}$ \\
\hline Prosocial behaviour Scale & & & & $\begin{array}{c}-0.0836^{* *} \\
(0.0325)\end{array}$ & $\begin{array}{c}-0.0883^{* * *} \\
(0.0332)\end{array}$ \\
\hline Child height for age z-score & & & & $\begin{array}{l}0.139^{* * *} \\
(0.0417)\end{array}$ & $\begin{array}{c}0.132^{* * *} \\
(0.0423)\end{array}$ \\
\hline Child weight for age z-score & & & & $\begin{array}{c}0.0475 \\
(0.0396)\end{array}$ & $\begin{array}{c}0.0465 \\
(0.0403)\end{array}$ \\
\hline Dubowitz gestational age z-score & & & & $\begin{array}{c}-0.00112 \\
(0.0353)\end{array}$ & $\begin{array}{c}0.0115 \\
(0.0358)\end{array}$ \\
\hline Weight z-score at birth & & & & $\begin{array}{c}0.0304 \\
(0.0550)\end{array}$ & $\begin{array}{c}0.0265 \\
(0.0554)\end{array}$ \\
\hline Height z-score at birth & & & & $\begin{array}{l}-0.0408 \\
(0.0418)\end{array}$ & $\begin{array}{l}-0.0354 \\
(0.0421)\end{array}$ \\
\hline Head circumference z-score at birth & & & & $\begin{array}{c}0.0199 \\
(0.0470)\end{array}$ & $\begin{array}{c}0.0157 \\
(0.0474)\end{array}$ \\
\hline Child rating of relationship with father & & & & & $\begin{array}{l}0.0590^{*} \\
(0.0317)\end{array}$ \\
\hline Child rating of relationship with mum & & & & & $\begin{array}{c}0.0622 \\
(0.0414)\end{array}$ \\
\hline Beatings in the past 6 months & & & & & $\begin{array}{l}-0.0710^{*} \\
(0.0363)\end{array}$ \\
\hline Number of books or magazines read p.w. & & & & & $\begin{array}{c}0.0262^{* *} \\
(0.0115)\end{array}$ \\
\hline Constant & $\begin{array}{c}8.724^{* * *} \\
(0.0341)\end{array}$ & $\begin{array}{c}8.605^{* * *} \\
(1.118)\end{array}$ & $\begin{array}{c}6.508^{* * *} \\
(1.115)\end{array}$ & $\begin{array}{c}5.770^{* * *} \\
(0.967)\end{array}$ & $\begin{array}{c}5.530^{* * *} \\
(0.994)\end{array}$ \\
\hline Observations & 3,318 & 3,310 & 3,026 & 2,915 & 2,795 \\
\hline R-squared & 0.221 & 0.304 & 0.349 & 0.536 & 0.533 \\
\hline
\end{tabular}


Table A.3: Probability of attending a post-secondary institution at age 18

\begin{tabular}{|c|c|c|c|c|c|}
\hline VARIABLES & $\begin{array}{c}(1) \\
\text { Post-Sec } \\
\end{array}$ & $\begin{array}{c}(2) \\
\text { Post-Sec } \\
\end{array}$ & $\begin{array}{c}(3) \\
\text { Post-Sec } \\
\end{array}$ & $\begin{array}{c}(4) \\
\text { Post-Sec } \\
\end{array}$ & $\begin{array}{c}(5) \\
\text { Post-Sec } \\
\end{array}$ \\
\hline Family income at birth in log & $\begin{array}{c}0.0504^{* * *} \\
(0.00658)\end{array}$ & $\begin{array}{c}0.0418^{* * *} \\
(0.00639)\end{array}$ & $\begin{array}{c}0.0229 * * * \\
(0.00755)\end{array}$ & $\begin{array}{c}0.00893^{*} \\
(0.00479)\end{array}$ & $\begin{array}{l}0.00916^{*} \\
(0.00516)\end{array}$ \\
\hline Family income at age $11 \mathrm{in} \log$ & $\begin{array}{c}0.0521 * * * \\
(0.00679)\end{array}$ & $\begin{array}{c}0.0465^{* * *} \\
(0.00649)\end{array}$ & $\begin{array}{c}0.0258^{* * *} \\
(0.00759)\end{array}$ & $\begin{array}{c}0.0178 * * * \\
(0.00511)\end{array}$ & $\begin{array}{c}0.0201 * * * \\
(0.00548)\end{array}$ \\
\hline Family income at age 18 in log & $\begin{array}{l}0.0155^{* *} \\
(0.00646)\end{array}$ & $\begin{array}{c}0.0179 * * * \\
(0.00616)\end{array}$ & $\begin{array}{l}0.0136^{* *} \\
(0.00645)\end{array}$ & $\begin{array}{c}0.00558 \\
(0.00409)\end{array}$ & $\begin{array}{c}0.00557 \\
(0.00434)\end{array}$ \\
\hline Male & & $\begin{array}{c}-0.0634^{* * *} \\
(0.0107)\end{array}$ & $\begin{array}{c}-0.0660 * * * \\
(0.0116)\end{array}$ & $\begin{array}{c}-0.0276^{* * *} \\
(0.00779)\end{array}$ & $\begin{array}{c}-0.0295 * * * \\
(0.00832)\end{array}$ \\
\hline Child is black or brown & & $\begin{array}{c}-0.0377^{* * *} \\
(0.0132)\end{array}$ & $\begin{array}{c}-0.0343^{* *} \\
(0.0144)\end{array}$ & $\begin{array}{l}-0.00968 \\
(0.00928)\end{array}$ & $\begin{array}{c}-0.00790 \\
(0.0100)\end{array}$ \\
\hline Age in decimals 2004 & & $\begin{array}{c}0.0377^{* *} \\
(0.0163)\end{array}$ & $\begin{array}{c}0.0436^{* *} \\
(0.0174)\end{array}$ & $\begin{array}{c}0.0292^{* * *} \\
(0.0110)\end{array}$ & $\begin{array}{c}0.0288^{* *} \\
(0.0118)\end{array}$ \\
\hline Number of pregnancies 1993 & & $\begin{array}{c}-0.0223^{* * *} \\
(0.00391)\end{array}$ & $\begin{array}{c}-0.0166^{* * *} \\
(0.00423)\end{array}$ & $\begin{array}{c}-0.00763^{* * *} \\
(0.00270)\end{array}$ & $\begin{array}{c}-0.00800 * * * \\
(0.00293)\end{array}$ \\
\hline Lives with husband or partner & & $\begin{array}{c}0.0281 \\
(0.0183)\end{array}$ & $\begin{array}{c}0.0283 \\
(0.0212)\end{array}$ & $\begin{array}{c}0.00262 \\
(0.0131)\end{array}$ & $\begin{array}{l}0.00488 \\
(0.0147)\end{array}$ \\
\hline Mother's education 1993 & & & $\begin{array}{c}0.00685^{* * *} \\
(0.00214)\end{array}$ & $\begin{array}{c}0.00303^{* *} \\
(0.00136)\end{array}$ & $\begin{array}{l}0.00282^{*} \\
(0.00146)\end{array}$ \\
\hline Father's education 1993 & & & $\begin{array}{c}0.00921 * * * \\
(0.00217)\end{array}$ & $\begin{array}{c}0.00444^{* * *} \\
(0.00139)\end{array}$ & $\begin{array}{c}0.00510^{* * * *} \\
(0.00152)\end{array}$ \\
\hline Mother psychological index (SQR-20)(-) & & & $\begin{array}{l}0.0171^{* *} \\
(0.00703)\end{array}$ & $\begin{array}{c}0.00460 \\
(0.00473)\end{array}$ & $\begin{array}{c}0.00424 \\
(0.00511)\end{array}$ \\
\hline Mother's social activity 2004 & & & $\begin{array}{c}0.00349 \\
(0.00222)\end{array}$ & $\begin{array}{l}0.00236^{*} \\
(0.00141)\end{array}$ & $\begin{array}{c}0.00226 \\
(0.00152)\end{array}$ \\
\hline Mother or father had emotional problems & & & $\begin{array}{c}-0.00529 \\
(0.0137)\end{array}$ & $\begin{array}{l}-0.00109 \\
(0.00860)\end{array}$ & $\begin{array}{l}0.000307 \\
(0.00928)\end{array}$ \\
\hline Mother's height z-score & & & $\begin{array}{l}-0.00269 \\
(0.00622)\end{array}$ & $\begin{array}{l}-0.00792^{*} \\
(0.00439)\end{array}$ & $\begin{array}{l}-0.00800^{*} \\
(0.00470)\end{array}$ \\
\hline Mother's weight z-score & & & $\begin{array}{c}0.00957 \\
(0.00628)\end{array}$ & $\begin{array}{c}0.00930 * * \\
(0.00411)\end{array}$ & $\begin{array}{l}0.0103^{* *} \\
(0.00438)\end{array}$ \\
\hline Hyperactivity Scale (-) & & & & $\begin{array}{c}0.0189 * * * \\
(0.00501)\end{array}$ & $\begin{array}{c}0.0202^{* * *} \\
(0.00531)\end{array}$ \\
\hline Conduct Problems Scale (-) & & & & $\begin{array}{l}0.0109^{* *} \\
(0.00552)\end{array}$ & $\begin{array}{l}0.00976^{*} \\
(0.00592)\end{array}$ \\
\hline Difficulties at school (1-4) & & & & $\begin{array}{l}-0.0128^{* *} \\
(0.00519)\end{array}$ & $\begin{array}{l}-0.0133^{* *} \\
(0.00557)\end{array}$ \\
\hline Number of grade retentions & & & & $\begin{array}{c}-0.109 * * * \\
(0.00863)\end{array}$ & $\begin{array}{c}-0.115 * * * \\
(0.00954)\end{array}$ \\
\hline Emotional Problems Scale (-) & & & & $\begin{array}{c}-0.0117^{* * *} \\
(0.00446)\end{array}$ & $\begin{array}{c}-0.00990^{* *} \\
(0.00474)\end{array}$ \\
\hline Peer Problems Scale (-) & & & & $\begin{array}{c}-0.00332 \\
(0.00443)\end{array}$ & $\begin{array}{l}-0.00397 \\
(0.00480)\end{array}$ \\
\hline Prosocial behaviour Scale & & & & $\begin{array}{l}-0.00306 \\
(0.00450)\end{array}$ & $\begin{array}{l}-0.00166 \\
(0.00478)\end{array}$ \\
\hline Child height for age z-score & & & & $\begin{array}{l}-0.00425 \\
(0.00541)\end{array}$ & $\begin{array}{l}-0.00437 \\
(0.00580)\end{array}$ \\
\hline Child weight for age z-score & & & & $\begin{array}{c}0.00700 \\
(0.00528)\end{array}$ & $\begin{array}{c}0.00835 \\
(0.00562)\end{array}$ \\
\hline Dubowitz gestational age z-score & & & & $\begin{array}{l}-0.00157 \\
(0.00451)\end{array}$ & $\begin{array}{l}-0.00167 \\
(0.00485)\end{array}$ \\
\hline Weight z-score at birth & & & & $\begin{array}{c}0.00760 \\
(0.00705)\end{array}$ & $\begin{array}{c}0.00792 \\
(0.00755)\end{array}$ \\
\hline Height z-score at birth & & & & $\begin{array}{c}0.00530 \\
(0.00571)\end{array}$ & $\begin{array}{c}0.00450 \\
(0.00605)\end{array}$ \\
\hline Head circumference z-score at birth & & & & $\begin{array}{l}-0.0137^{* *} \\
(0.00575)\end{array}$ & $\begin{array}{l}-0.0133^{* *} \\
(0.00620)\end{array}$ \\
\hline Child rating of relationship with father & & & & & $\begin{array}{l}-0.00478 \\
(0.00444)\end{array}$ \\
\hline Child rating of relationship with mum & & & & & $\begin{array}{c}0.00538 \\
(0.00619)\end{array}$ \\
\hline Beatings in the past 6 months & & & & & $\begin{array}{c}0.00113 \\
(0.00499)\end{array}$ \\
\hline Number of books or magazines read p.w. & & & & & $\begin{array}{l}0.000521 \\
(0.00152)\end{array}$ \\
\hline Observations & 3,319 & 3,311 & 3,027 & 2,916 & 2,796 \\
\hline
\end{tabular}


Table A.4: Probability of completing Secondary Education at age 18

\begin{tabular}{|c|c|c|c|c|c|}
\hline VARIABLES & $\begin{array}{c}(1) \\
\text { Sec. Ed. }\end{array}$ & $\begin{array}{c}2) \\
\text { Sec. Ed. }\end{array}$ & $\begin{array}{c}(3) \\
\text { Sec. Ed. }\end{array}$ & $\begin{array}{c}(4) \\
\text { Sec. Ed. }\end{array}$ & $\begin{array}{c}5) \\
\text { Sec. Ed. }\end{array}$ \\
\hline Family income at birth in $\log$ & $\begin{array}{c}0.124^{* * *} \\
(0.0104)\end{array}$ & $\begin{array}{c}0.110^{* * *} \\
(0.0104)\end{array}$ & $\begin{array}{c}0.0690^{* * *} \\
(0.0121)\end{array}$ & $\begin{array}{c}0.0415^{* * *} \\
(0.0109)\end{array}$ & $\begin{array}{c}0.0412^{* * *} \\
(0.0114)\end{array}$ \\
\hline Family income at age 11 in $\log$ & $\begin{array}{c}0.0887^{* * *} * \\
(0.0110)\end{array}$ & $\begin{array}{c}0.0795^{* * *} \\
(0.0110)\end{array}$ & $\begin{array}{c}0.0300^{* *} \\
(0.0124)\end{array}$ & $\begin{array}{l}0.0212^{*} \\
(0.0117)\end{array}$ & $\begin{array}{l}0.0216^{*} \\
(0.0123)\end{array}$ \\
\hline Family income at age 18 in log & $\begin{array}{c}0.0552^{* * *} \\
(0.0101)\end{array}$ & $\begin{array}{c}0.0636^{* * *} \\
(0.0101)\end{array}$ & $\begin{array}{c}0.0582^{* * *} \\
(0.0107)\end{array}$ & $\begin{array}{c}0.0407 * * * \\
(0.00968)\end{array}$ & $\begin{array}{c}0.0423^{* * *} \\
(0.0100)\end{array}$ \\
\hline Male & & $\begin{array}{c}-0.161^{* * * *} \\
(0.0168)\end{array}$ & $\begin{array}{c}-0.170^{* * * *} \\
(0.0183)\end{array}$ & $\begin{array}{c}-0.0986^{* * *} \\
(0.0169)\end{array}$ & $\begin{array}{c}-0.105^{* * *} \\
(0.0179)\end{array}$ \\
\hline Child is black or brown & & $\begin{array}{c}-0.113^{* * *} \\
(0.0200)\end{array}$ & $\begin{array}{c}-0.104^{* * * *} \\
(0.0217)\end{array}$ & $\begin{array}{c}-0.0633^{* * *} \\
(0.0201)\end{array}$ & $\begin{array}{c}-0.0555^{* * *} \\
(0.0212)\end{array}$ \\
\hline Age in decimals 2004 & & $\begin{array}{c}0.0788^{* * *} \\
(0.0256)\end{array}$ & $\begin{array}{c}0.101^{* * *} \\
(0.0275)\end{array}$ & $\begin{array}{c}0.0969 * * * \\
(0.0251)\end{array}$ & $\begin{array}{c}0.0953^{* * *} \\
(0.0263)\end{array}$ \\
\hline Number of pregnancies 1993 & & $\begin{array}{c}-0.0391^{* * *} \\
(0.00604)\end{array}$ & $\begin{array}{c}-0.0279^{* * *} \\
(0.00674)\end{array}$ & $\begin{array}{c}-0.0158^{* *} \\
(0.00652)\end{array}$ & $\begin{array}{c}-0.0189 * * * \\
(0.00695)\end{array}$ \\
\hline Lives with husband or partner & & $\begin{array}{c}0.0888^{* * *} \\
(0.0287)\end{array}$ & $\begin{array}{c}0.119 * * * \\
(0.0336)\end{array}$ & $\begin{array}{c}0.0639 * * \\
(0.0313)\end{array}$ & $\begin{array}{c}0.0713^{* *} \\
(0.0337)\end{array}$ \\
\hline Mother's education 1993 & & & $\begin{array}{c}0.0220 * * * \\
(0.00353)\end{array}$ & $\begin{array}{c}0.0152^{* * *} \\
(0.00323)\end{array}$ & $\begin{array}{c}0.0153^{* * *} * \\
(0.00340)\end{array}$ \\
\hline Father's education 1993 & & & $\begin{array}{c}0.0182^{* * *} \\
(0.00346)\end{array}$ & $\begin{array}{c}0.0140 * * * \\
(0.00314)\end{array}$ & $\begin{array}{c}0.0149 * * * \\
(0.00332)\end{array}$ \\
\hline Mother psychological index (SQR-20)(-) & & & $\begin{array}{c}0.0379^{* * *} \\
(0.0110)\end{array}$ & $\begin{array}{c}0.00661 \\
(0.0111)\end{array}$ & $\begin{array}{l}0.00342 \\
(0.0117)\end{array}$ \\
\hline Mother's social activity 2004 & & & $\begin{array}{c}0.00509 \\
(0.00349)\end{array}$ & $\begin{array}{c}0.00369 \\
(0.00318)\end{array}$ & $\begin{array}{c}0.00342 \\
(0.00335)\end{array}$ \\
\hline Mother or father had emotional problems & & & $\begin{array}{c}-0.0475^{* *} \\
(0.0214)\end{array}$ & $\begin{array}{c}-0.0351^{*} \\
(0.0200)\end{array}$ & $\begin{array}{c}-0.0360^{*} \\
(0.0209)\end{array}$ \\
\hline Mother's height z-score & & & $\begin{array}{c}0.00806 \\
(0.00985)\end{array}$ & $\begin{array}{c}-0.00879 \\
(0.00943)\end{array}$ & $\begin{array}{l}-0.00998 \\
(0.01000)\end{array}$ \\
\hline Mother's weight z-score & & & $\begin{array}{c}-0.00413 \\
(0.0102)\end{array}$ & $\begin{array}{l}-0.00278 \\
(0.00928)\end{array}$ & $\begin{array}{c}-0.00229 \\
(0.00973)\end{array}$ \\
\hline Hyperactivity Scale (-) & & & & $\begin{array}{c}0.0661^{* * *} \\
(0.0104)\end{array}$ & $\begin{array}{c}0.0667^{* * *} \\
(0.0108)\end{array}$ \\
\hline Conduct Problems Scale (-) & & & & $\begin{array}{c}0.0367 * * * \\
(0.0118)\end{array}$ & $\begin{array}{c}0.0353^{* * * *} \\
(0.0126)\end{array}$ \\
\hline Difficulties at school (1-4) & & & & $\begin{array}{c}-0.0448^{* * *} \\
(0.0113)\end{array}$ & $\begin{array}{c}-0.0453^{* * *} \\
(0.0119)\end{array}$ \\
\hline Number of grade retentions & & & & $\begin{array}{c}-0.253^{* * *} \\
(0.0228)\end{array}$ & $\begin{array}{c}-0.254^{* * *} * \\
(0.0243)\end{array}$ \\
\hline Emotional Problems Scale (-) & & & & $\begin{array}{c}-0.0398^{* * *} \\
(0.0102)\end{array}$ & $\begin{array}{c}-0.0374^{* * *} \\
(0.0107)\end{array}$ \\
\hline Peer Problems Scale (-) & & & & $\begin{array}{c}0.00632 \\
(0.00991)\end{array}$ & $\begin{array}{l}0.00841 \\
(0.0105)\end{array}$ \\
\hline Prosocial behaviour Scale & & & & $\begin{array}{c}-0.0152 \\
(0.00965)\end{array}$ & $\begin{array}{l}-0.0129 \\
(0.0101)\end{array}$ \\
\hline Child height for age z-score & & & & $\begin{array}{c}0.0155 \\
(0.0122)\end{array}$ & $\begin{array}{c}0.0164 \\
(0.0128)\end{array}$ \\
\hline Child weight for age z-score & & & & $\begin{array}{c}0.0149 \\
(0.0115)\end{array}$ & $\begin{array}{c}0.0174 \\
(0.0120)\end{array}$ \\
\hline Dubowitz gestational age z-score & & & & $\begin{array}{c}-0.00529 \\
(0.0102)\end{array}$ & $\begin{array}{c}-0.00318 \\
(0.0107)\end{array}$ \\
\hline Weight z-score at birth & & & & $\begin{array}{c}0.00231 \\
(0.0164)\end{array}$ & $\begin{array}{c}-0.00123 \\
(0.0171)\end{array}$ \\
\hline Height z-score at birth & & & & $\begin{array}{c}-0.00141 \\
(0.0126)\end{array}$ & $\begin{array}{c}-0.00122 \\
(0.0132)\end{array}$ \\
\hline Head circumference z-score at birth & & & & $\begin{array}{l}0.00287 \\
(0.0134)\end{array}$ & $\begin{array}{l}0.00615 \\
(0.0141)\end{array}$ \\
\hline Child rating of relationship with father & & & & & $\begin{array}{l}-0.00827 \\
(0.00966)\end{array}$ \\
\hline Child rating of relationship with mum & & & & & $\begin{array}{c}0.0116 \\
(0.0134)\end{array}$ \\
\hline Beatings in the past 6 months & & & & & $\begin{array}{l}-0.0143 \\
(0.0110)\end{array}$ \\
\hline Number of books or magazines read p.w. & & & & & $\begin{array}{c}0.00200 \\
(0.00343)\end{array}$ \\
\hline Observations & 3,318 & 3,310 & 3,026 & 2,915 & 2,795 \\
\hline
\end{tabular}


Table A.5: Probability of having at least one child at age 18

\begin{tabular}{|c|c|c|c|c|c|}
\hline VARIABLES & $\begin{array}{c}(1) \\
\text { Child }\end{array}$ & $\begin{array}{c}(2) \\
\text { Child }\end{array}$ & $\begin{array}{c}(3) \\
\text { Child }\end{array}$ & $\begin{array}{c}(4) \\
\text { Child }\end{array}$ & $\begin{array}{c}(5) \\
\text { Child } \\
\end{array}$ \\
\hline Family income at birth in $\log$ & $\begin{array}{c}-0.0266^{* * *} \\
(0.00573)\end{array}$ & $\begin{array}{c}-0.0248^{* * *} \\
(0.00537)\end{array}$ & $\begin{array}{c}-0.0123^{* *} \\
(0.00561)\end{array}$ & $\begin{array}{c}-0.0104^{*} \\
(0.00571)\end{array}$ & $\begin{array}{c}-0.0128^{* *} \\
(0.00571)\end{array}$ \\
\hline Family income at age 11 in $\log$ & $\begin{array}{c}-0.0300^{* * * *} \\
(0.00571)\end{array}$ & $\begin{array}{c}-0.0262^{* * *} \\
(0.00523)\end{array}$ & $\begin{array}{c}-0.0173^{* * * *} \\
(0.00551)\end{array}$ & $\begin{array}{c}-0.0171^{* * *} \\
(0.00552)\end{array}$ & $\begin{array}{c}-0.0159 * * * \\
(0.00549)\end{array}$ \\
\hline Family income at age 18 in $\log$ & $\begin{array}{c}-0.0255^{* * *} \\
(0.00451)\end{array}$ & $\begin{array}{c}-0.0172^{* * *} \\
(0.00410)\end{array}$ & $\begin{array}{c}-0.0126 * * * \\
(0.00423)\end{array}$ & $\begin{array}{c}-0.00768^{*} \\
(0.00425)\end{array}$ & $\begin{array}{c}-0.00808^{*} \\
(0.00427)\end{array}$ \\
\hline Male & & $\begin{array}{c}-0.0878^{* * *} * \\
(0.00848)\end{array}$ & $\begin{array}{c}-0.0780^{* * * *} \\
(0.00847)\end{array}$ & $\begin{array}{c}-0.0830 * * * \\
(0.00883)\end{array}$ & $\begin{array}{c}-0.0814^{* * *} \\
(0.00894)\end{array}$ \\
\hline Child is black or brown & & $\begin{array}{c}0.0239 * * * \\
(0.00887)\end{array}$ & $\begin{array}{c}0.0226^{* * *} \\
(0.00878)\end{array}$ & $\begin{array}{c}0.0242^{* * *} \\
(0.00886)\end{array}$ & $\begin{array}{c}0.0239 * * * \\
(0.00900)\end{array}$ \\
\hline Age in decimals 2004 & & $\begin{array}{c}0.0283^{* *} \\
(0.0124)\end{array}$ & $\begin{array}{l}0.0233^{*} \\
(0.0123)\end{array}$ & $\begin{array}{l}0.0218^{*} \\
(0.0122)\end{array}$ & $\begin{array}{c}0.0324^{* * *} \\
(0.0121)\end{array}$ \\
\hline Number of pregnancies 1993 & & $\begin{array}{c}0.00872^{* * *} * \\
(0.00221)\end{array}$ & $\begin{array}{l}0.00455^{*} \\
(0.00239)\end{array}$ & $\begin{array}{c}0.00326 \\
(0.00244)\end{array}$ & $\begin{array}{c}0.00360 \\
(0.00248)\end{array}$ \\
\hline Lives with husband or partner & & $\begin{array}{c}-0.00538 \\
(0.0130)\end{array}$ & $\begin{array}{c}-0.00790 \\
(0.0143)\end{array}$ & $\begin{array}{c}-0.00240 \\
(0.0148)\end{array}$ & $\begin{array}{c}-0.00305 \\
(0.0149)\end{array}$ \\
\hline Mother's education 1993 & & & $\begin{array}{c}-0.00606^{* * *} \\
(0.00176)\end{array}$ & $\begin{array}{c}-0.00515^{* * *} * \\
(0.00178)\end{array}$ & $\begin{array}{c}-0.00435^{* * * *} \\
(0.00166)\end{array}$ \\
\hline Father's education 1993 & & & $\begin{array}{l}-0.00131 \\
(0.00167)\end{array}$ & $\begin{array}{r}-0.000865 \\
(0.00166)\end{array}$ & $\begin{array}{l}-0.00115 \\
(0.00163)\end{array}$ \\
\hline Mother psychological index (SQR-20)(-) & & & $\begin{array}{l}-0.00460 \\
(0.00426)\end{array}$ & $\begin{array}{c}-0.00290 \\
(0.00449)\end{array}$ & $\begin{array}{c}-8.71 \mathrm{e}-05 \\
(0.00460)\end{array}$ \\
\hline Mother's social activity 2004 & & & $\begin{array}{c}-0.00138 \\
(0.00157)\end{array}$ & $\begin{array}{r}-0.000586 \\
(0.00156)\end{array}$ & $\begin{array}{c}-0.000662 \\
(0.00157)\end{array}$ \\
\hline Mother or father had emotional problems & & & $\begin{array}{c}0.0102 \\
(0.00884)\end{array}$ & $\begin{array}{c}0.00574 \\
(0.00891)\end{array}$ & $\begin{array}{c}0.00598 \\
(0.00901)\end{array}$ \\
\hline Mother's height z-score & & & $\begin{array}{l}-0.0120^{* *} \\
(0.00484)\end{array}$ & $\begin{array}{c}-0.0103^{* *} \\
(0.00516)\end{array}$ & $\begin{array}{l}-0.00988^{*} \\
(0.00512)\end{array}$ \\
\hline Mother's weight z-score & & & $\begin{array}{l}-0.00527 \\
(0.00455)\end{array}$ & $\begin{array}{l}-0.00454 \\
(0.00474)\end{array}$ & $\begin{array}{c}-0.00588 \\
(0.00471)\end{array}$ \\
\hline Hyperactivity Scale (-) & & & & $\begin{array}{l}-0.00177 \\
(0.00513)\end{array}$ & $\begin{array}{l}-0.00305 \\
(0.00510)\end{array}$ \\
\hline Conduct Problems Scale (-) & & & & $\begin{array}{l}-0.00990^{*} \\
(0.00534)\end{array}$ & $\begin{array}{l}-0.00958^{*} \\
(0.00542)\end{array}$ \\
\hline Difficulties at school (1-4) & & & & $\begin{array}{l}0.000550 \\
(0.00480)\end{array}$ & $\begin{array}{l}-0.00183 \\
(0.00482)\end{array}$ \\
\hline Number of grade retentions & & & & $\begin{array}{c}0.0134^{* * *} \\
(0.00470)\end{array}$ & $\begin{array}{c}0.0143 * * * \\
(0.00482)\end{array}$ \\
\hline Emotional Problems Scale (-) & & & & $\begin{array}{c}0.00953^{* *} \\
(0.00463)\end{array}$ & $\begin{array}{c}0.00573 \\
(0.00464)\end{array}$ \\
\hline Peer Problems Scale (-) & & & & $\begin{array}{l}-0.00455 \\
(0.00459)\end{array}$ & $\begin{array}{l}-0.00272 \\
(0.00464)\end{array}$ \\
\hline Prosocial behaviour Scale & & & & $\begin{array}{c}0.000764 \\
(0.00449)\end{array}$ & $\begin{array}{r}-0.000317 \\
(0.00451)\end{array}$ \\
\hline Child height for age z-score & & & & $\begin{array}{c}-0.00299 \\
(0.00595)\end{array}$ & $\begin{array}{c}-0.00409 \\
(0.00596)\end{array}$ \\
\hline Child weight for age z-score & & & & $\begin{array}{l}-0.00490 \\
(0.00564)\end{array}$ & $\begin{array}{l}-0.00413 \\
(0.00568)\end{array}$ \\
\hline Dubowitz gestational age z-score & & & & $\begin{array}{l}-0.00474 \\
(0.00501)\end{array}$ & $\begin{array}{l}-0.00450 \\
(0.00504)\end{array}$ \\
\hline Weight z-score at birth & & & & $\begin{array}{c}-0.00815 \\
(0.00829)\end{array}$ & $\begin{array}{c}-0.0107 \\
(0.00832)\end{array}$ \\
\hline Height z-score at birth & & & & $\begin{array}{c}0.00819 \\
(0.00591)\end{array}$ & $\begin{array}{c}0.00872 \\
(0.00600)\end{array}$ \\
\hline Head circumference z-score at birth & & & & $\begin{array}{c}0.00362 \\
(0.00714)\end{array}$ & $\begin{array}{c}0.00490 \\
(0.00733)\end{array}$ \\
\hline Child rating of relationship with father & & & & & $\begin{array}{c}-0.00636 \\
(0.00398)\end{array}$ \\
\hline Child rating of relationship with mum & & & & & $\begin{array}{c}0.00697 \\
(0.00528)\end{array}$ \\
\hline Beatings in the past 6 months & & & & & $\begin{array}{c}0.00523 \\
(0.00464)\end{array}$ \\
\hline Number of books or magazines read p.w. & & & & & $\begin{array}{c}0.00147 \\
(0.00175)\end{array}$ \\
\hline Observations & 3,318 & 3,311 & 3,027 & 2,916 & 2,796 \\
\hline
\end{tabular}


Table A.6: Health problems index at age 18

\begin{tabular}{|c|c|c|c|c|c|}
\hline VARIABLES & $\begin{array}{l}(1) \\
\text { Inc. }\end{array}$ & $\begin{array}{l}(2) \\
\text { Inc. }\end{array}$ & $\begin{array}{l}(3) \\
\text { Inc. }\end{array}$ & $\begin{array}{l}(4) \\
\text { Inc. }\end{array}$ & $\begin{array}{l}\text { (5) } \\
\text { Inc. }\end{array}$ \\
\hline Family income at birth in $\log$ & $\begin{array}{c}-0.0112 * * * \\
(0.00420)\end{array}$ & $\begin{array}{c}-0.00882^{* *} \\
(0.00347)\end{array}$ & $\begin{array}{l}-0.00583 \\
(0.00371)\end{array}$ & $\begin{array}{l}-0.00432 \\
(0.00341)\end{array}$ & $\begin{array}{l}-0.00376 \\
(0.00353)\end{array}$ \\
\hline Family income at age 11 in $\log$ & $\begin{array}{l}-0.00269 \\
(0.00440)\end{array}$ & $\begin{array}{l}-0.00133 \\
(0.00354)\end{array}$ & $\begin{array}{c}0.00303 \\
(0.00373)\end{array}$ & $\begin{array}{c}0.00285 \\
(0.00363)\end{array}$ & $\begin{array}{c}0.00233 \\
(0.00362)\end{array}$ \\
\hline Family income at age 18 in $\log$ & $\begin{array}{l}-0.00194 \\
(0.00375)\end{array}$ & $\begin{array}{l}-0.00388 \\
(0.00308)\end{array}$ & $\begin{array}{c}-0.00296 \\
(0.00314)\end{array}$ & $\begin{array}{l}-0.00107 \\
(0.00303)\end{array}$ & $\begin{array}{c}-0.00109 \\
(0.00312)\end{array}$ \\
\hline Male & & $\begin{array}{c}0.0451^{* * *} \\
(0.00587)\end{array}$ & $\begin{array}{c}0.0449 * * * \\
(0.00570)\end{array}$ & $\begin{array}{c}0.0366^{* * *} \\
(0.00560)\end{array}$ & $\begin{array}{c}0.0370^{* * *} * \\
(0.00569)\end{array}$ \\
\hline Child is black or brown & & $\begin{array}{c}0.00779 \\
(0.00626)\end{array}$ & $\begin{array}{c}0.00674 \\
(0.00623)\end{array}$ & $\begin{array}{c}0.00506 \\
(0.00588)\end{array}$ & $\begin{array}{c}0.00386 \\
(0.00602)\end{array}$ \\
\hline Age in decimals 2004 & & $\begin{array}{c}0.0234 * * * \\
(0.00901)\end{array}$ & $\begin{array}{c}0.0156^{*} \\
(0.00886)\end{array}$ & $\begin{array}{c}0.0137 \\
(0.00849)\end{array}$ & $\begin{array}{c}0.0145^{*} \\
(0.00866)\end{array}$ \\
\hline Number of pregnancies 1993 & & $\begin{array}{c}0.00265^{*} \\
(0.00152)\end{array}$ & $\begin{array}{r}-0.000147 \\
(0.00162)\end{array}$ & $\begin{array}{l}-0.000427 \\
(0.00152)\end{array}$ & $\begin{array}{l}-6.21 \mathrm{e}-05 \\
(0.00156)\end{array}$ \\
\hline Lives with husband or partner & & $\begin{array}{c}-0.0201^{* *} \\
(0.00810)\end{array}$ & $\begin{array}{l}-0.0147^{*} \\
(0.00891)\end{array}$ & $\begin{array}{l}-0.00811 \\
(0.00831)\end{array}$ & $\begin{array}{c}-0.00702 \\
(0.00874)\end{array}$ \\
\hline Mother's education 1993 & & & $\begin{array}{c}-0.000583 \\
(0.00112)\end{array}$ & $\begin{array}{l}-0.000312 \\
(0.00108)\end{array}$ & $\begin{array}{r}-0.000287 \\
(0.00108)\end{array}$ \\
\hline Father's education 1993 & & & $\begin{array}{c}-0.000363 \\
(0.00102)\end{array}$ & $\begin{array}{c}1.82 \mathrm{e}-06 \\
(0.000956)\end{array}$ & $\begin{array}{l}-0.000156 \\
(0.000992)\end{array}$ \\
\hline Mother psychological index (SQR-20)(-) & & & $\begin{array}{c}-0.00912^{* * *} \\
(0.00299)\end{array}$ & $\begin{array}{c}-0.00632^{* *} \\
(0.00311)\end{array}$ & $\begin{array}{c}-0.00575^{*} \\
(0.00320)\end{array}$ \\
\hline Mother's social activity 2004 & & & $\begin{array}{r}-0.000717 \\
(0.00120)\end{array}$ & $\begin{array}{r}-0.000179 \\
(0.00110)\end{array}$ & $\begin{array}{r}-0.000297 \\
(0.00113)\end{array}$ \\
\hline Mother or father had emotional problems & & & $\begin{array}{c}0.00747 \\
(0.00639)\end{array}$ & $\begin{array}{c}0.00560 \\
(0.00615)\end{array}$ & $\begin{array}{c}0.00490 \\
(0.00635)\end{array}$ \\
\hline Mother's height z-score & & & $\begin{array}{l}-0.00240 \\
(0.00314)\end{array}$ & $\begin{array}{l}-0.00402 \\
(0.00324)\end{array}$ & $\begin{array}{c}-0.00465 \\
(0.00329)\end{array}$ \\
\hline Mother's weight z-score & & & $\begin{array}{l}-0.00308 \\
(0.00282)\end{array}$ & $\begin{array}{l}-0.00217 \\
(0.00272)\end{array}$ & $\begin{array}{l}-0.00140 \\
(0.00275)\end{array}$ \\
\hline Hyperactivity Scale (-) & & & & $\begin{array}{l}-0.00151 \\
(0.00332)\end{array}$ & $\begin{array}{c}-0.00144 \\
(0.00340)\end{array}$ \\
\hline Conduct Problems Scale (-) & & & & $\begin{array}{c}-0.0133 * * * \\
(0.00333)\end{array}$ & $\begin{array}{c}-0.0124^{* * *} \\
(0.00346)\end{array}$ \\
\hline Difficulties at school (1-4) & & & & $\begin{array}{l}-0.00186 \\
(0.00298)\end{array}$ & $\begin{array}{r}-0.000997 \\
(0.00301)\end{array}$ \\
\hline Number of grade retentions & & & & $\begin{array}{c}0.00691^{* *} \\
(0.00278)\end{array}$ & $\begin{array}{c}0.00671^{* *} \\
(0.00293)\end{array}$ \\
\hline Emotional Problems Scale (-) & & & & $\begin{array}{c}0.00469 \\
(0.00311)\end{array}$ & $\begin{array}{c}0.00487 \\
(0.00317)\end{array}$ \\
\hline Peer Problems Scale (-) & & & & $\begin{array}{c}0.00256 \\
(0.00298)\end{array}$ & $\begin{array}{c}0.00223 \\
(0.00307)\end{array}$ \\
\hline Prosocial behaviour Scale & & & & $\begin{array}{l}-0.00223 \\
(0.00257)\end{array}$ & $\begin{array}{c}-0.00114 \\
(0.00268)\end{array}$ \\
\hline Child height for age z-score & & & & $\begin{array}{l}-0.00101 \\
(0.00359)\end{array}$ & $\begin{array}{r}-0.000312 \\
(0.00365)\end{array}$ \\
\hline Child weight for age z-score & & & & $\begin{array}{l}0.00661^{*} \\
(0.00356)\end{array}$ & $\begin{array}{l}0.00614^{*} \\
(0.00361)\end{array}$ \\
\hline Dubowitz gestational age z-score & & & & $\begin{array}{c}0.00159 \\
(0.00334)\end{array}$ & $\begin{array}{c}0.00122 \\
(0.00334)\end{array}$ \\
\hline Weight z-score at birth & & & & $\begin{array}{l}0.001000 \\
(0.00515)\end{array}$ & $\begin{array}{c}0.00164 \\
(0.00522)\end{array}$ \\
\hline Height z-score at birth & & & & $\begin{array}{l}0.000904 \\
(0.00407)\end{array}$ & $\begin{array}{c}0.000369 \\
(0.00410)\end{array}$ \\
\hline Head circumference z-score at birth & & & & $\begin{array}{c}-0.000416 \\
(0.00424)\end{array}$ & $\begin{array}{l}-0.00110 \\
(0.00436)\end{array}$ \\
\hline Child rating of relationship with father & & & & & $\begin{array}{c}-0.00513^{* *} \\
(0.00258)\end{array}$ \\
\hline Child rating of relationship with mum & & & & & $\begin{array}{c}0.00225 \\
(0.00336)\end{array}$ \\
\hline Beatings in the past 6 months & & & & & $\begin{array}{c}0.000931 \\
(0.00279)\end{array}$ \\
\hline Number of books or magazines read p.w. & & & & & $\begin{array}{c}-8.71 \mathrm{e}-05 \\
(0.00114)\end{array}$ \\
\hline Observations & 3,317 & 3,310 & 3,026 & 2,916 & 2,796 \\
\hline
\end{tabular}


Table A.7: Schooling at age 11

\begin{tabular}{|c|c|c|c|c|c|}
\hline VARIABLES & $\begin{array}{c}(1) \\
\text { Educ. }\end{array}$ & $\begin{array}{c}(2) \\
\text { Educ. }\end{array}$ & $\begin{array}{c}(3) \\
\text { Educ. }\end{array}$ & $\begin{array}{c}(4) \\
\text { Educ. }\end{array}$ & $\begin{array}{c}(5) \\
\text { Educ. }\end{array}$ \\
\hline Family income at birth in $\log$ & $\begin{array}{c}0.244^{* * *} \\
(0.0204)\end{array}$ & $\begin{array}{c}0.189 * * * \\
(0.0192)\end{array}$ & $\begin{array}{c}0.0766^{* * *} \\
(0.0199)\end{array}$ & $\begin{array}{c}0.0748^{* * *} \\
(0.0202)\end{array}$ & $\begin{array}{c}0.0517^{* *} \\
(0.0204)\end{array}$ \\
\hline Family income at age 11 in $\log$ & $\begin{array}{c}0.260^{* * *} \\
(0.0210)\end{array}$ & $\begin{array}{c}0.227^{* * *} * \\
(0.0195)\end{array}$ & $\begin{array}{c}0.127^{* * *} \\
(0.0194)\end{array}$ & $\begin{array}{c}0.131^{* * *} \\
(0.0195)\end{array}$ & $\begin{array}{c}0.117^{* * *} \\
(0.0195)\end{array}$ \\
\hline Male & & $\begin{array}{c}-0.275^{* * * *} \\
(0.0300)\end{array}$ & $\begin{array}{c}-0.275^{* * * *} \\
(0.0295)\end{array}$ & $\begin{array}{c}-0.277^{* * * *} \\
(0.0297)\end{array}$ & $\begin{array}{c}-0.280 * * * \\
(0.0294)\end{array}$ \\
\hline Child is black or brown & & $\begin{array}{c}-0.241^{* * *} \\
(0.0370)\end{array}$ & $\begin{array}{c}-0.181^{* * *} \\
(0.0370)\end{array}$ & $\begin{array}{c}-0.165^{* * *} \\
(0.0372)\end{array}$ & $\begin{array}{c}-0.135 * * * \\
(0.0369)\end{array}$ \\
\hline Age in decimals 2004 & & $\begin{array}{c}0.720^{* * *} \\
(0.0468)\end{array}$ & $\begin{array}{c}0.762^{* * *} \\
(0.0466)\end{array}$ & $\begin{array}{c}0.751^{* * *} \\
(0.0471)\end{array}$ & $\begin{array}{c}0.786^{* * *} \\
(0.0470)\end{array}$ \\
\hline Number of pregnancies 1993 & & $\begin{array}{c}-0.121^{* * *} \\
(0.0112)\end{array}$ & $\begin{array}{c}-0.0954^{* * *} \\
(0.0117)\end{array}$ & $\begin{array}{c}-0.100^{* * *} \\
(0.0117)\end{array}$ & $\begin{array}{c}-0.0890^{* * *} \\
(0.0122)\end{array}$ \\
\hline Lives with husband or partner & & $\begin{array}{l}0.131^{* *} \\
(0.0510)\end{array}$ & $\begin{array}{l}0.115^{* *} \\
(0.0532)\end{array}$ & $\begin{array}{c}0.105^{*} \\
(0.0548)\end{array}$ & $\begin{array}{c}0.0966 \\
(0.0590)\end{array}$ \\
\hline Mother's education 1993 & & & $\begin{array}{c}0.0511^{* * *} \\
(0.00598)\end{array}$ & $\begin{array}{c}0.0512^{* * *} \\
(0.00597)\end{array}$ & $\begin{array}{c}0.0415^{* * *} \\
(0.00572)\end{array}$ \\
\hline Father's education 1993 & & & $\begin{array}{c}0.0225^{* * *} \\
(0.00564)\end{array}$ & $\begin{array}{c}0.0212^{* * *} \\
(0.00572)\end{array}$ & $\begin{array}{c}0.0214^{* * *} * \\
(0.00569)\end{array}$ \\
\hline Mother psychological index (SQR-20)(-) & & & $\begin{array}{c}0.0911^{* * *} \\
(0.0185)\end{array}$ & $\begin{array}{c}0.0839^{* * *} \\
(0.0185)\end{array}$ & $\begin{array}{c}0.0741^{* * *} * \\
(0.0184)\end{array}$ \\
\hline Mother's social activity 2004 & & & $\begin{array}{c}0.00304 \\
(0.00587)\end{array}$ & $\begin{array}{c}0.00383 \\
(0.00595)\end{array}$ & $\begin{array}{c}0.00181 \\
(0.00585)\end{array}$ \\
\hline Mother or father had emotional problems & & & $\begin{array}{l}-0.0335 \\
(0.0361)\end{array}$ & $\begin{array}{l}-0.0338 \\
(0.0366)\end{array}$ & $\begin{array}{l}-0.0334 \\
(0.0360)\end{array}$ \\
\hline Mother's height z-score & & & $\begin{array}{c}0.0438^{* * * *} \\
(0.0168)\end{array}$ & $\begin{array}{c}0.0277 \\
(0.0173)\end{array}$ & $\begin{array}{c}0.0280 \\
(0.0177)\end{array}$ \\
\hline Mother's weight z-score & & & $\begin{array}{c}0.0120 \\
(0.0164)\end{array}$ & $\begin{array}{l}0.00389 \\
(0.0164)\end{array}$ & $\begin{array}{l}0.00343 \\
(0.0164)\end{array}$ \\
\hline Dubowitz gestational age z-score & & & & $\begin{array}{r}-0.00106 \\
(0.0192)\end{array}$ & $\begin{array}{l}0.00522 \\
(0.0192)\end{array}$ \\
\hline Weight z-score at birth & & & & $\begin{array}{c}0.0386 \\
(0.0350)\end{array}$ & $\begin{array}{c}0.0110 \\
(0.0345)\end{array}$ \\
\hline Height z-score at birth & & & & $\begin{array}{l}0.0438^{*} \\
(0.0230)\end{array}$ & $\begin{array}{c}0.0489^{* *} \\
(0.0227)\end{array}$ \\
\hline Head circumference z-score at birth & & & & $\begin{array}{c}0.0111 \\
(0.0255)\end{array}$ & $\begin{array}{c}0.00658 \\
(0.0248)\end{array}$ \\
\hline Thorax circumference at birth z-score & & & & $\begin{array}{c}0.0183 \\
(0.0299)\end{array}$ & $\begin{array}{c}0.0177 \\
(0.0285)\end{array}$ \\
\hline Abdomen circumference z-score at birth & & & & $\begin{array}{c}-0.0150 \\
(0.0228)\end{array}$ & $\begin{array}{l}-0.0156 \\
(0.0223)\end{array}$ \\
\hline Month at first pre-natal visit & & & & & $\begin{array}{c}-0.0330^{* * *} \\
(0.0112)\end{array}$ \\
\hline Number of Pre-natal visits & & & & & $\begin{array}{c}0.0191^{* * *} \\
(0.00559)\end{array}$ \\
\hline Prenatal quality $0-10$ & & & & & $\begin{array}{l}0.00409 \\
(0.0112)\end{array}$ \\
\hline Smoked during pregnancy & & & & & $\begin{array}{c}-0.0589^{*} \\
(0.0351)\end{array}$ \\
\hline Constant & $\begin{array}{c}3.583^{* * *} \\
(0.0163)\end{array}$ & $\begin{array}{c}-4.168^{* * *} \\
(0.532)\end{array}$ & $\begin{array}{c}-5.195^{* * *} \\
(0.532)\end{array}$ & $\begin{array}{c}-5.062^{* * *} \\
(0.538)\end{array}$ & $\begin{array}{c}-5.457^{* * * *} \\
(0.550)\end{array}$ \\
\hline Observations & 3,708 & 3,693 & 3,370 & 3,283 & 3,136 \\
\hline R-squared & 0.165 & 0.280 & 0.324 & 0.331 & 0.337 \\
\hline
\end{tabular}


Table A.8: SDQ conduct problems score age 11

\begin{tabular}{|c|c|c|c|c|c|}
\hline VARIABLES & $\begin{array}{c}(1) \\
\text { Conduct }\end{array}$ & $\begin{array}{c}(2) \\
\text { Conduct } \\
\end{array}$ & $\begin{array}{c}(3) \\
\text { Conduct } \\
\end{array}$ & $\begin{array}{c}(4) \\
\text { Conduct }\end{array}$ & $\begin{array}{c}(5) \\
\text { Conduct }\end{array}$ \\
\hline Family income at birth in log & $\begin{array}{c}0.120^{* * *} \\
(0.0183)\end{array}$ & $\begin{array}{c}0.113^{* * *} \\
(0.0185)\end{array}$ & $\begin{array}{c}0.0572^{* * *} \\
(0.0197)\end{array}$ & $\begin{array}{c}0.0531^{* * *} \\
(0.0201)\end{array}$ & $\begin{array}{c}0.0477^{* *} \\
(0.0207)\end{array}$ \\
\hline Family income at age 11 in $\log$ & $\begin{array}{c}0.126^{* * *} \\
(0.0193)\end{array}$ & $\begin{array}{c}0.111^{* * *} \\
(0.0194)\end{array}$ & $\begin{array}{c}0.0158 \\
(0.0211)\end{array}$ & $\begin{array}{c}0.0121 \\
(0.0215)\end{array}$ & $\begin{array}{l}0.00485 \\
(0.0220)\end{array}$ \\
\hline Male & & $\begin{array}{c}-0.165^{* * *} \\
(0.0314)\end{array}$ & $\begin{array}{c}-0.153^{* * *} \\
(0.0311)\end{array}$ & $\begin{array}{c}-0.155^{* * *} \\
(0.0317)\end{array}$ & $\begin{array}{c}-0.152^{* * *} \\
(0.0321)\end{array}$ \\
\hline Child is black or brown & & $\begin{array}{c}-0.0806^{* *} \\
(0.0369)\end{array}$ & $\begin{array}{c}-0.0383 \\
(0.0372)\end{array}$ & $\begin{array}{c}-0.0283 \\
(0.0377)\end{array}$ & $\begin{array}{l}-0.0189 \\
(0.0387)\end{array}$ \\
\hline Age in decimals 2004 & & $\begin{array}{c}-0.0691 \\
(0.0480)\end{array}$ & $\begin{array}{l}-0.0532 \\
(0.0478)\end{array}$ & $\begin{array}{l}-0.0447 \\
(0.0491)\end{array}$ & $\begin{array}{l}-0.0496 \\
(0.0493)\end{array}$ \\
\hline Number of pregnancies 1993 & & $\begin{array}{c}-0.0382^{* * *} \\
(0.0106)\end{array}$ & $\begin{array}{c}-0.00328 \\
(0.0114)\end{array}$ & $\begin{array}{c}-0.00696 \\
(0.0115)\end{array}$ & $\begin{array}{l}0.00286 \\
(0.0115)\end{array}$ \\
\hline Lives with husband or partner & & $\begin{array}{c}0.224^{* * *} \\
(0.0558)\end{array}$ & $\begin{array}{c}0.240^{* * *} \\
(0.0619)\end{array}$ & $\begin{array}{c}0.256^{* * *} \\
(0.0632)\end{array}$ & $\begin{array}{c}0.230^{* * *} \\
(0.0668)\end{array}$ \\
\hline Mother's education 1993 & & & $\begin{array}{c}0.0174^{* * *} \\
(0.00601)\end{array}$ & $\begin{array}{c}0.0170^{* * *} \\
(0.00609)\end{array}$ & $\begin{array}{c}0.0147^{* *} \\
(0.00619)\end{array}$ \\
\hline Father's education 1993 & & & $\begin{array}{l}0.0128^{* *} \\
(0.00580)\end{array}$ & $\begin{array}{l}0.0139 * * \\
(0.00586)\end{array}$ & $\begin{array}{c}0.0133^{* *} \\
(0.00593)\end{array}$ \\
\hline Mother psychological index (SQR-20)(-) & & & $\begin{array}{c}0.258^{* * *} \\
(0.0190)\end{array}$ & $\begin{array}{c}0.256^{* * *} \\
(0.0194)\end{array}$ & $\begin{array}{c}0.247^{* * *} \\
(0.0196)\end{array}$ \\
\hline Mother's social activity 2004 & & & $\begin{array}{c}0.0326^{* * *} \\
(0.00627)\end{array}$ & $\begin{array}{c}0.0328^{* * * *} \\
(0.00640)\end{array}$ & $\begin{array}{c}0.0317 * * * \\
(0.00652)\end{array}$ \\
\hline Mother or father had emotional problems & & & $\begin{array}{c}-0.142^{* * *} \\
(0.0379)\end{array}$ & $\begin{array}{c}-0.139 * * * \\
(0.0388)\end{array}$ & $\begin{array}{c}-0.142^{* * *} \\
(0.0392)\end{array}$ \\
\hline Mother's height z-score & & & $\begin{array}{c}0.00225 \\
(0.0174)\end{array}$ & $\begin{array}{c}-0.00548 \\
(0.0184)\end{array}$ & $\begin{array}{l}-0.0153 \\
(0.0188)\end{array}$ \\
\hline Mother's weight z-score & & & $\begin{array}{c}0.00564 \\
(0.0178)\end{array}$ & $\begin{array}{l}0.00809 \\
(0.0181)\end{array}$ & $\begin{array}{c}0.0200 \\
(0.0184)\end{array}$ \\
\hline Dubowitz gestational age z-score & & & & $\begin{array}{c}-0.0198 \\
(0.0201)\end{array}$ & $\begin{array}{c}-0.0173 \\
(0.0206)\end{array}$ \\
\hline Weight z-score at birth & & & & $\begin{array}{c}-0.0178 \\
(0.0361)\end{array}$ & $\begin{array}{l}-0.0176 \\
(0.0364)\end{array}$ \\
\hline Height z-score at birth & & & & $\begin{array}{l}0.00733 \\
(0.0251)\end{array}$ & $\begin{array}{l}0.00140 \\
(0.0250)\end{array}$ \\
\hline Head circumference z-score at birth & & & & $\begin{array}{c}0.0186 \\
(0.0270)\end{array}$ & $\begin{array}{c}0.0223 \\
(0.0273)\end{array}$ \\
\hline Thorax circumference at birth z-score & & & & $\begin{array}{l}-0.0170 \\
(0.0335)\end{array}$ & $\begin{array}{l}-0.0161 \\
(0.0335)\end{array}$ \\
\hline Abdomen circumference z-score at birth & & & & $\begin{array}{c}0.0508^{* *} \\
(0.0246)\end{array}$ & $\begin{array}{c}0.0339 \\
(0.0252)\end{array}$ \\
\hline Month at first pre-natal visit & & & & & $\begin{array}{c}0.00252 \\
(0.0115)\end{array}$ \\
\hline Number of Pre-natal visits & & & & & $\begin{array}{c}0.0102 \\
(0.00627)\end{array}$ \\
\hline Prenatal quality $0-10$ & & & & & $\begin{array}{c}0.000956 \\
(0.0116)\end{array}$ \\
\hline Smoked during pregnancy & & & & & $\begin{array}{c}-0.165 * * * \\
(0.0375)\end{array}$ \\
\hline Constant & $\begin{array}{c}0.0189 \\
(0.0158)\end{array}$ & $\begin{array}{c}0.799 \\
(0.546)\end{array}$ & $\begin{array}{c}0.109 \\
(0.548)\end{array}$ & $\begin{array}{c}-0.00196 \\
(0.562)\end{array}$ & $\begin{array}{l}0.0379 \\
(0.577)\end{array}$ \\
\hline Observations & 3,699 & 3,682 & 3,360 & 3,273 & 3,126 \\
\hline R-squared & 0.048 & 0.064 & 0.160 & 0.161 & 0.165 \\
\hline
\end{tabular}


Table A.9: SDQ hyperactivity and attentional problems score age 11

\begin{tabular}{|c|c|c|c|c|c|}
\hline VARIABLES & $\begin{array}{c}(1) \\
\text { Hyper }\end{array}$ & $\begin{array}{c}(2) \\
\text { Hyper }\end{array}$ & $\begin{array}{c}(3) \\
\text { Hyper }\end{array}$ & $\begin{array}{c}(4) \\
\text { Hyper }\end{array}$ & $\begin{array}{c}(5) \\
\text { Hyper }\end{array}$ \\
\hline Family income at birth in $\log$ & $\begin{array}{c}0.113^{* * *} \\
(0.0191)\end{array}$ & $\begin{array}{c}0.105^{* * *} \\
(0.0189)\end{array}$ & $\begin{array}{c}0.0604^{* * *} \\
(0.0211)\end{array}$ & $\begin{array}{c}0.0542^{* *} \\
(0.0214)\end{array}$ & $\begin{array}{c}0.0495^{* *} \\
(0.0219)\end{array}$ \\
\hline Family income at age 11 in $\log$ & $\begin{array}{c}0.0645^{* * *} \\
(0.0194)\end{array}$ & $\begin{array}{c}0.0543^{* * *} \\
(0.0195)\end{array}$ & $\begin{array}{c}-0.0148 \\
(0.0215)\end{array}$ & $\begin{array}{c}-0.0126 \\
(0.0218)\end{array}$ & $\begin{array}{l}-0.0216 \\
(0.0225)\end{array}$ \\
\hline Male & & $\begin{array}{c}-0.323^{* * *} \\
(0.0322)\end{array}$ & $\begin{array}{c}-0.308^{* * *} \\
(0.0327)\end{array}$ & $\begin{array}{c}-0.304^{* * *} \\
(0.0332)\end{array}$ & $\begin{array}{c}-0.315^{* * *} \\
(0.0339)\end{array}$ \\
\hline Child is black or brown & & $\begin{array}{c}-0.0948^{* * *} \\
(0.0366)\end{array}$ & $\begin{array}{c}-0.102^{* * *} \\
(0.0380)\end{array}$ & $\begin{array}{c}-0.0868^{* *} \\
(0.0386)\end{array}$ & $\begin{array}{r}-0.0862^{* *} \\
(0.0401)\end{array}$ \\
\hline Age in decimals 2004 & & $\begin{array}{l}-0.0487 \\
(0.0494)\end{array}$ & $\begin{array}{l}-0.0435 \\
(0.0507)\end{array}$ & $\begin{array}{l}-0.0285 \\
(0.0520)\end{array}$ & $\begin{array}{c}-0.0394 \\
(0.0532)\end{array}$ \\
\hline Number of pregnancies 1993 & & $\begin{array}{c}-0.0204^{* *} \\
(0.00982)\end{array}$ & $\begin{array}{l}0.00857 \\
(0.0103)\end{array}$ & $\begin{array}{l}0.00620 \\
(0.0105)\end{array}$ & $\begin{array}{c}0.0116 \\
(0.0113)\end{array}$ \\
\hline Lives with husband or partner & & $\begin{array}{c}0.168^{* * *} \\
(0.0536)\end{array}$ & $\begin{array}{l}0.123^{* *} \\
(0.0607)\end{array}$ & $\begin{array}{c}0.125^{* *} \\
(0.0618)\end{array}$ & $\begin{array}{c}0.0957 \\
(0.0658)\end{array}$ \\
\hline Mother's education 1993 & & & $\begin{array}{c}0.0142^{* *} \\
(0.00650)\end{array}$ & $\begin{array}{l}0.0137 * * \\
(0.00655)\end{array}$ & $\begin{array}{c}0.0122^{*} \\
(0.00680)\end{array}$ \\
\hline Father's education 1993 & & & $\begin{array}{c}0.0111^{*} \\
(0.00619)\end{array}$ & $\begin{array}{c}0.0120^{*} \\
(0.00624)\end{array}$ & $\begin{array}{c}0.0111^{*} \\
(0.00634)\end{array}$ \\
\hline Mother psychological index (SQR-20)(-) & & & $\begin{array}{c}0.217^{* * *} \\
(0.0191)\end{array}$ & $\begin{array}{c}0.214^{* * *} \\
(0.0194)\end{array}$ & $\begin{array}{c}0.207^{* * *} \\
(0.0200)\end{array}$ \\
\hline Mother's social activity 2004 & & & $\begin{array}{l}0.0131^{* *} \\
(0.00637)\end{array}$ & $\begin{array}{c}0.0126^{*} \\
(0.00648)\end{array}$ & $\begin{array}{c}0.0117^{*} \\
(0.00669)\end{array}$ \\
\hline Mother or father had emotional problems & & & $\begin{array}{c}-0.101^{* * *} \\
(0.0386)\end{array}$ & $\begin{array}{c}-0.102^{* * *} \\
(0.0392)\end{array}$ & $\begin{array}{c}-0.110^{* * *} \\
(0.0401)\end{array}$ \\
\hline Mother's height z-score & & & $\begin{array}{c}0.0286 \\
(0.0183)\end{array}$ & $\begin{array}{c}0.0206 \\
(0.0191)\end{array}$ & $\begin{array}{c}0.0136 \\
(0.0195)\end{array}$ \\
\hline Mother's weight z-score & & & $\begin{array}{c}-0.00642 \\
(0.0185)\end{array}$ & $\begin{array}{c}-0.000473 \\
(0.0188)\end{array}$ & $\begin{array}{l}0.00943 \\
(0.0194)\end{array}$ \\
\hline Dubowitz gestational age z-score & & & & $\begin{array}{c}0.00626 \\
(0.0211)\end{array}$ & $\begin{array}{c}0.00519 \\
(0.0218)\end{array}$ \\
\hline Weight z-score at birth & & & & $\begin{array}{l}-0.0276 \\
(0.0380)\end{array}$ & $\begin{array}{c}-0.0296 \\
(0.0388)\end{array}$ \\
\hline Height z-score at birth & & & & $\begin{array}{c}0.00941 \\
(0.0239)\end{array}$ & $\begin{array}{c}0.00238 \\
(0.0243)\end{array}$ \\
\hline Head circumference z-score at birth & & & & $\begin{array}{c}0.0287 \\
(0.0279)\end{array}$ & $\begin{array}{c}0.0313 \\
(0.0287)\end{array}$ \\
\hline Thorax circumference at birth z-score & & & & $\begin{array}{c}-0.00148 \\
(0.0321)\end{array}$ & $\begin{array}{l}0.00149 \\
(0.0327)\end{array}$ \\
\hline Abdomen circumference z-score at birth & & & & $\begin{array}{c}0.0247 \\
(0.0255)\end{array}$ & $\begin{array}{c}0.0154 \\
(0.0262)\end{array}$ \\
\hline Month at first pre-natal visit & & & & & $\begin{array}{c}-0.0169 \\
(0.0120)\end{array}$ \\
\hline Number of Pre-natal visits & & & & & $\begin{array}{l}0.000307 \\
(0.00647)\end{array}$ \\
\hline Prenatal quality $0-10$ & & & & & $\begin{array}{r}0.00353 \\
(0.0126)\end{array}$ \\
\hline Smoked during pregnancy & & & & & $\begin{array}{c}-0.144^{* * *} \\
(0.0389)\end{array}$ \\
\hline Constant & $\begin{array}{l}0.00614 \\
(0.0163)\end{array}$ & $\begin{array}{c}0.645 \\
(0.562)\end{array}$ & $\begin{array}{c}0.319 \\
(0.582)\end{array}$ & $\begin{array}{c}0.149 \\
(0.597)\end{array}$ & $\begin{array}{c}0.376 \\
(0.627)\end{array}$ \\
\hline Observations & 3,700 & 3,683 & 3,363 & 3,277 & 3,131 \\
\hline R-squared & 0.024 & 0.056 & 0.115 & 0.114 & 0.119 \\
\hline
\end{tabular}


Table A.10: SDQ emotional problems score age 11

\begin{tabular}{|c|c|c|c|c|c|}
\hline VARIABLES & $\begin{array}{c}(1) \\
\text { Emotions } \\
\end{array}$ & $\begin{array}{c}(2) \\
\text { Emotions } \\
\end{array}$ & $\begin{array}{c}(3) \\
\text { Emotions } \\
\end{array}$ & $\begin{array}{c}(4) \\
\text { Emotions } \\
\end{array}$ & $\begin{array}{c}5) \\
\text { Emotions }\end{array}$ \\
\hline Family income at birth in log & $\begin{array}{c}0.0259 \\
(0.0196)\end{array}$ & $\begin{array}{c}0.0235 \\
(0.0198)\end{array}$ & $\begin{array}{c}-0.0350^{*} \\
(0.0209)\end{array}$ & $\begin{array}{l}-0.0335 \\
(0.0214)\end{array}$ & $\begin{array}{c}-0.0452^{* *} \\
(0.0218)\end{array}$ \\
\hline Family income at age 11 in $\log$ & $\begin{array}{c}0.163^{* * *} \\
(0.0194)\end{array}$ & $\begin{array}{c}0.151^{* * *} \\
(0.0197)\end{array}$ & $\begin{array}{c}0.0703^{* * *} * \\
(0.0210)\end{array}$ & $\begin{array}{c}0.0685^{* * *} * \\
(0.0213)\end{array}$ & $\begin{array}{c}0.0730^{* * *} * \\
(0.0217)\end{array}$ \\
\hline Male & & $\begin{array}{c}0.119 * * * \\
(0.0323)\end{array}$ & $\begin{array}{c}0.140 * * * \\
(0.0311)\end{array}$ & $\begin{array}{c}0.130 * * * \\
(0.0316)\end{array}$ & $\begin{array}{c}0.121^{* * *} \\
(0.0321)\end{array}$ \\
\hline Child is black or brown & & $\begin{array}{c}-0.110^{* * * *} \\
(0.0380)\end{array}$ & $\begin{array}{c}-0.0947^{* *} \\
(0.0374)\end{array}$ & $\begin{array}{c}-0.0928^{* *} \\
(0.0378)\end{array}$ & $\begin{array}{c}-0.103^{* * *} \\
(0.0388)\end{array}$ \\
\hline Age in decimals 2004 & & $\begin{array}{c}-0.0308 \\
(0.0500)\end{array}$ & $\begin{array}{l}-0.0152 \\
(0.0480)\end{array}$ & $\begin{array}{c}0.00794 \\
(0.0490)\end{array}$ & $\begin{array}{c}0.0169 \\
(0.0496)\end{array}$ \\
\hline Number of pregnancies 1993 & & $\begin{array}{c}-0.00837 \\
(0.0103)\end{array}$ & $\begin{array}{c}0.0332^{* * *} \\
(0.0103)\end{array}$ & $\begin{array}{c}0.0310^{* * *} * \\
(0.0105)\end{array}$ & $\begin{array}{c}0.0278^{* *} \\
(0.0110)\end{array}$ \\
\hline Lives with husband or partner & & $\begin{array}{c}-0.0153 \\
(0.0524)\end{array}$ & $\begin{array}{l}-0.0543 \\
(0.0558)\end{array}$ & $\begin{array}{l}-0.0442 \\
(0.0568)\end{array}$ & $\begin{array}{l}-0.0520 \\
(0.0599)\end{array}$ \\
\hline Mother's education 1993 & & & $\begin{array}{c}0.0215^{* * *} \\
(0.00636)\end{array}$ & $\begin{array}{c}0.0211^{* * *} \\
(0.00642)\end{array}$ & $\begin{array}{c}0.0225^{* * *} * \\
(0.00659)\end{array}$ \\
\hline Father's education 1993 & & & $\begin{array}{c}0.00893 \\
(0.00604)\end{array}$ & $\begin{array}{c}0.00924 \\
(0.00611)\end{array}$ & $\begin{array}{c}0.00953 \\
(0.00619)\end{array}$ \\
\hline Mother psychological index (SQR-20)(-) & & & $\begin{array}{c}0.352^{* * *} \\
(0.0187)\end{array}$ & $\begin{array}{c}0.351^{* * *} \\
(0.0190)\end{array}$ & $\begin{array}{c}0.350^{* * *} \\
(0.0193)\end{array}$ \\
\hline Mother's social activity 2004 & & & $\begin{array}{c}0.000549 \\
(0.00573)\end{array}$ & $\begin{array}{c}0.000923 \\
(0.00577)\end{array}$ & $\begin{array}{c}0.000885 \\
(0.00590)\end{array}$ \\
\hline Mother or father had emotional problems & & & $\begin{array}{c}-0.137^{* * * *} \\
(0.0375)\end{array}$ & $\begin{array}{c}-0.142^{* * *} \\
(0.0381)\end{array}$ & $\begin{array}{c}-0.152^{* * *} \\
(0.0386)\end{array}$ \\
\hline Mother's height z-score & & & $\begin{array}{c}0.0155 \\
(0.0172)\end{array}$ & $\begin{array}{c}0.0168 \\
(0.0180)\end{array}$ & $\begin{array}{c}0.0215 \\
(0.0184)\end{array}$ \\
\hline Mother's weight z-score & & & $\begin{array}{c}-0.00875 \\
(0.0178)\end{array}$ & $\begin{array}{c}-0.00643 \\
(0.0181)\end{array}$ & $\begin{array}{c}-0.00270 \\
(0.0184)\end{array}$ \\
\hline Dubowitz gestational age z-score & & & & $\begin{array}{l}0.00995 \\
(0.0203)\end{array}$ & $\begin{array}{c}0.0128 \\
(0.0208)\end{array}$ \\
\hline Weight z-score at birth & & & & $\begin{array}{c}-0.0200 \\
(0.0360)\end{array}$ & $\begin{array}{l}-0.0165 \\
(0.0367)\end{array}$ \\
\hline Height z-score at birth & & & & $\begin{array}{l}0.00309 \\
(0.0245)\end{array}$ & $\begin{array}{l}0.00302 \\
(0.0247)\end{array}$ \\
\hline Head circumference z-score at birth & & & & $\begin{array}{c}0.0167 \\
(0.0257)\end{array}$ & $\begin{array}{c}0.0172 \\
(0.0261)\end{array}$ \\
\hline Thorax circumference at birth z-score & & & & $\begin{array}{c}-0.00174 \\
(0.0339)\end{array}$ & $\begin{array}{l}0.00782 \\
(0.0341)\end{array}$ \\
\hline Abdomen circumference z-score at birth & & & & $\begin{array}{l}0.00754 \\
(0.0253)\end{array}$ & $\begin{array}{c}0.000450 \\
(0.0260)\end{array}$ \\
\hline Month at first pre-natal visit & & & & & $\begin{array}{r}-0.00142 \\
(0.0117)\end{array}$ \\
\hline Number of Pre-natal visits & & & & & $\begin{array}{c}-0.00667 \\
(0.00647)\end{array}$ \\
\hline Prenatal quality $0-10$ & & & & & $\begin{array}{c}0.0134 \\
(0.0117)\end{array}$ \\
\hline Smoked during pregnancy & & & & & $\begin{array}{c}-0.0588 \\
(0.0374)\end{array}$ \\
\hline Constant & $\begin{array}{c}0.0156 \\
(0.0162)\end{array}$ & $\begin{array}{c}0.370 \\
(0.570)\end{array}$ & $\begin{array}{l}-0.0668 \\
(0.552)\end{array}$ & $\begin{array}{l}-0.325 \\
(0.562)\end{array}$ & $\begin{array}{l}-0.436 \\
(0.582)\end{array}$ \\
\hline Observations & 3,699 & 3,681 & 3,358 & 3,273 & 3,128 \\
\hline R-squared & 0.032 & 0.038 & 0.183 & 0.184 & 0.191 \\
\hline
\end{tabular}


Table A.11: SDQ peer relations problems score age 11

\begin{tabular}{|c|c|c|c|c|c|}
\hline VARIABLES & $\begin{array}{c}1) \\
\text { Peer }\end{array}$ & $\begin{array}{c}(2) \\
\text { Peer }\end{array}$ & $\begin{array}{c}(3) \\
\text { Peer } \\
\end{array}$ & $\begin{array}{c}(4) \\
\text { Peer }\end{array}$ & $\begin{array}{c}5) \\
\text { Peer }\end{array}$ \\
\hline Family income at birth in $\log$ & $\begin{array}{c}0.102^{* * *} \\
(0.0194)\end{array}$ & $\begin{array}{c}0.106^{* * *} \\
(0.0196)\end{array}$ & $\begin{array}{c}0.0417^{*} \\
(0.0215)\end{array}$ & $\begin{array}{c}0.0420^{*} \\
(0.0219)\end{array}$ & $\begin{array}{c}0.0303 \\
(0.0225)\end{array}$ \\
\hline Family income at age 11 in $\log$ & $\begin{array}{c}0.140^{* * *} * \\
(0.0193)\end{array}$ & $\begin{array}{c}0.138^{* * *} \\
(0.0196)\end{array}$ & $\begin{array}{c}0.0592^{* * *} \\
(0.0215)\end{array}$ & $\begin{array}{c}0.0570^{* * *} * \\
(0.0219)\end{array}$ & $\begin{array}{c}0.0561^{* *} \\
(0.0225)\end{array}$ \\
\hline Male & & $\begin{array}{c}0.0257 \\
(0.0319)\end{array}$ & $\begin{array}{c}0.0435 \\
(0.0319)\end{array}$ & $\begin{array}{c}0.0387 \\
(0.0325)\end{array}$ & $\begin{array}{c}0.0353 \\
(0.0330)\end{array}$ \\
\hline Child is black or brown & & $\begin{array}{c}0.0288 \\
(0.0370)\end{array}$ & $\begin{array}{c}0.0445 \\
(0.0382)\end{array}$ & $\begin{array}{c}0.0483 \\
(0.0390)\end{array}$ & $\begin{array}{c}0.0523 \\
(0.0397)\end{array}$ \\
\hline Age in decimals 2004 & & $\begin{array}{c}-0.107^{* *} \\
(0.0498)\end{array}$ & $\begin{array}{c}-0.0936^{*} \\
(0.0497)\end{array}$ & $\begin{array}{c}-0.0867^{*} \\
(0.0507)\end{array}$ & $\begin{array}{l}-0.0745 \\
(0.0516)\end{array}$ \\
\hline Number of pregnancies 1993 & & $\begin{array}{c}-0.0202^{*} \\
(0.0104)\end{array}$ & $\begin{array}{c}0.0134 \\
(0.0111)\end{array}$ & $\begin{array}{c}0.0114 \\
(0.0112)\end{array}$ & $\begin{array}{l}0.0214^{*} \\
(0.0119)\end{array}$ \\
\hline Lives with husband or partner & & $\begin{array}{l}0.121^{* *} \\
(0.0562)\end{array}$ & $\begin{array}{c}0.0930 \\
(0.0623)\end{array}$ & $\begin{array}{c}0.0954 \\
(0.0630)\end{array}$ & $\begin{array}{c}0.0796 \\
(0.0656)\end{array}$ \\
\hline Mother's education 1993 & & & $\begin{array}{c}0.0365^{* * *} \\
(0.00642)\end{array}$ & $\begin{array}{c}0.0371 * * * \\
(0.00650)\end{array}$ & $\begin{array}{c}0.0339 * * * \\
(0.00661)\end{array}$ \\
\hline Father's education 1993 & & & $\begin{array}{r}-0.000100 \\
(0.00605)\end{array}$ & $\begin{array}{r}-0.000467 \\
(0.00611)\end{array}$ & $\begin{array}{r}-0.000265 \\
(0.00625)\end{array}$ \\
\hline Mother psychological index (SQR-20)(-) & & & $\begin{array}{c}0.207^{* * *} \\
(0.0194)\end{array}$ & $\begin{array}{c}0.204^{* * *} \\
(0.0197)\end{array}$ & $\begin{array}{c}0.200^{* * *} \\
(0.0200)\end{array}$ \\
\hline Mother's social activity 2004 & & & $\begin{array}{c}0.00895 \\
(0.00599)\end{array}$ & $\begin{array}{c}0.00831 \\
(0.00606)\end{array}$ & $\begin{array}{c}0.00466 \\
(0.00607)\end{array}$ \\
\hline Mother or father had emotional problems & & & $\begin{array}{c}-0.107^{* * *} \\
(0.0385)\end{array}$ & $\begin{array}{c}-0.110^{* * *} \\
(0.0392)\end{array}$ & $\begin{array}{c}-0.0905^{* *} \\
(0.0398)\end{array}$ \\
\hline Mother's height z-score & & & $\begin{array}{c}0.00696 \\
(0.0185)\end{array}$ & $\begin{array}{c}-0.00276 \\
(0.0193)\end{array}$ & $\begin{array}{c}-0.00606 \\
(0.0198)\end{array}$ \\
\hline Mother's weight z-score & & & $\begin{array}{c}0.00726 \\
(0.0183)\end{array}$ & $\begin{array}{c}0.00902 \\
(0.0188)\end{array}$ & $\begin{array}{l}0.00586 \\
(0.0191)\end{array}$ \\
\hline Dubowitz gestational age z-score & & & & $\begin{array}{c}-0.0106 \\
(0.0203)\end{array}$ & $\begin{array}{c}-0.00940 \\
(0.0209)\end{array}$ \\
\hline Weight z-score at birth & & & & $\begin{array}{c}-0.0572 \\
(0.0387)\end{array}$ & $\begin{array}{c}-0.0688^{*} \\
(0.0385)\end{array}$ \\
\hline Height z-score at birth & & & & $\begin{array}{c}0.0628^{* *} \\
(0.0249)\end{array}$ & $\begin{array}{c}0.0634^{* *} \\
(0.0251)\end{array}$ \\
\hline Head circumference z-score at birth & & & & $\begin{array}{l}-0.0275 \\
(0.0272)\end{array}$ & $\begin{array}{l}-0.0244 \\
(0.0272)\end{array}$ \\
\hline Thorax circumference at birth z-score & & & & $\begin{array}{c}0.0159 \\
(0.0327)\end{array}$ & $\begin{array}{c}0.0164 \\
(0.0323)\end{array}$ \\
\hline Abdomen circumference z-score at birth & & & & $\begin{array}{c}0.0646 * * \\
(0.0254)\end{array}$ & $\begin{array}{c}0.0594^{* *} \\
(0.0260)\end{array}$ \\
\hline Month at first pre-natal visit & & & & & $\begin{array}{c}-0.00636 \\
(0.0117)\end{array}$ \\
\hline Number of Pre-natal visits & & & & & $\begin{array}{c}0.00547 \\
(0.00661)\end{array}$ \\
\hline Prenatal quality $0-10$ & & & & & $\begin{array}{c}0.0162 \\
(0.0122)\end{array}$ \\
\hline Smoked during pregnancy & & & & & $\begin{array}{c}-0.125 * * * \\
(0.0376)\end{array}$ \\
\hline Constant & $\begin{array}{c}0.0115 \\
(0.0160)\end{array}$ & $\begin{array}{c}1.145^{* *} \\
(0.566)\end{array}$ & $\begin{array}{c}0.648 \\
(0.568)\end{array}$ & $\begin{array}{c}0.579 \\
(0.579)\end{array}$ & $\begin{array}{c}0.374 \\
(0.602)\end{array}$ \\
\hline Observations & 3,702 & 3,684 & 3,362 & 3,275 & 3,129 \\
\hline R-squared & 0.046 & 0.050 & 0.115 & 0.119 & 0.119 \\
\hline
\end{tabular}


Table A.12: SDQ pro-social behaviour score age 11

\begin{tabular}{|c|c|c|c|c|c|}
\hline VARIABLES & $\begin{array}{c}(1) \\
\text { Pro-social } \\
\end{array}$ & $\begin{array}{c}(2) \\
\text { Pro-social } \\
\end{array}$ & $\begin{array}{c}(3) \\
\text { Pro-social } \\
\end{array}$ & $\begin{array}{c}(4) \\
\text { Pro-social }\end{array}$ & $\begin{array}{c}5) \\
\text { Pro-social } \\
\end{array}$ \\
\hline Family income at birth in $\log$ & $\begin{array}{c}0.0335^{*} \\
(0.0200)\end{array}$ & $\begin{array}{c}0.0337^{*} \\
(0.0200)\end{array}$ & $\begin{array}{c}0.0106 \\
(0.0220)\end{array}$ & $\begin{array}{l}0.00913 \\
(0.0226)\end{array}$ & $\begin{array}{l}0.00567 \\
(0.0233)\end{array}$ \\
\hline Family income at age 11 in log & $\begin{array}{l}0.0356^{*} \\
(0.0198)\end{array}$ & $\begin{array}{c}0.0316 \\
(0.0200)\end{array}$ & $\begin{array}{c}-0.00459 \\
(0.0224)\end{array}$ & $\begin{array}{c}-0.000318 \\
(0.0229)\end{array}$ & $\begin{array}{c}-0.00144 \\
(0.0235)\end{array}$ \\
\hline Male & & $\begin{array}{c}-0.124^{* * * *} \\
(0.0323)\end{array}$ & $\begin{array}{c}-0.114^{* * *} \\
(0.0334)\end{array}$ & $\begin{array}{c}-0.115^{* * * *} \\
(0.0343)\end{array}$ & $\begin{array}{c}-0.117^{* * * *} \\
(0.0346)\end{array}$ \\
\hline Child is black or brown & & $\begin{array}{l}0.00403 \\
(0.0373)\end{array}$ & $\begin{array}{c}0.0245 \\
(0.0395)\end{array}$ & $\begin{array}{c}0.0324 \\
(0.0402)\end{array}$ & $\begin{array}{c}0.0309 \\
(0.0408)\end{array}$ \\
\hline Age in decimals 2004 & & $\begin{array}{l}-0.0506 \\
(0.0477)\end{array}$ & $\begin{array}{l}-0.0570 \\
(0.0497)\end{array}$ & $\begin{array}{c}-0.0624 \\
(0.0513)\end{array}$ & $\begin{array}{l}-0.0680 \\
(0.0526)\end{array}$ \\
\hline Number of pregnancies 1993 & & $\begin{array}{c}-0.0131 \\
(0.0109)\end{array}$ & $\begin{array}{c}-0.00141 \\
(0.0123)\end{array}$ & $\begin{array}{c}-0.00249 \\
(0.0125)\end{array}$ & $\begin{array}{l}0.00377 \\
(0.0134)\end{array}$ \\
\hline Lives with husband or partner & & $\begin{array}{c}0.105^{*} \\
(0.0545)\end{array}$ & $\begin{array}{c}0.0706 \\
(0.0637)\end{array}$ & $\begin{array}{c}0.0741 \\
(0.0656)\end{array}$ & $\begin{array}{c}-0.0198 \\
(0.0657)\end{array}$ \\
\hline Mother's education 1993 & & & $\begin{array}{l}-0.00305 \\
(0.00671)\end{array}$ & $\begin{array}{l}-0.00319 \\
(0.00681)\end{array}$ & $\begin{array}{l}-0.00374 \\
(0.00691)\end{array}$ \\
\hline Father's education 1993 & & & $\begin{array}{c}0.0120^{*} \\
(0.00648)\end{array}$ & $\begin{array}{c}0.0129 * \\
(0.00659)\end{array}$ & $\begin{array}{c}0.0103 \\
(0.00669)\end{array}$ \\
\hline Mother psychological index (SQR-20)(-) & & & $\begin{array}{c}0.0820^{* * *} * \\
(0.0208)\end{array}$ & $\begin{array}{c}0.0821 * * * \\
(0.0212)\end{array}$ & $\begin{array}{c}0.0772^{* * *} \\
(0.0213)\end{array}$ \\
\hline Mother's social activity 2004 & & & $\begin{array}{c}0.0168^{* *} \\
(0.00670)\end{array}$ & $\begin{array}{c}0.0173^{* *} \\
(0.00679)\end{array}$ & $\begin{array}{l}0.0148^{* *} \\
(0.00678)\end{array}$ \\
\hline Mother or father had emotional problems & & & $\begin{array}{c}-0.0826^{* *} \\
(0.0395)\end{array}$ & $\begin{array}{c}-0.0706^{*} \\
(0.0404)\end{array}$ & $\begin{array}{l}-0.0604 \\
(0.0408)\end{array}$ \\
\hline Mother's height z-score & & & $\begin{array}{l}-0.0119 \\
(0.0201)\end{array}$ & $\begin{array}{l}-0.0192 \\
(0.0212)\end{array}$ & $\begin{array}{l}-0.0275 \\
(0.0215)\end{array}$ \\
\hline Mother's weight z-score & & & $\begin{array}{c}0.0205 \\
(0.0195)\end{array}$ & $\begin{array}{c}0.0218 \\
(0.0201)\end{array}$ & $\begin{array}{c}0.0239 \\
(0.0201)\end{array}$ \\
\hline Dubowitz gestational age z-score & & & & $\begin{array}{c}-0.00164 \\
(0.0203)\end{array}$ & $\begin{array}{l}0.00596 \\
(0.0209)\end{array}$ \\
\hline Weight z-score at birth & & & & $\begin{array}{c}-0.00404 \\
(0.0427)\end{array}$ & $\begin{array}{c}-0.00295 \\
(0.0412)\end{array}$ \\
\hline Height z-score at birth & & & & $\begin{array}{c}-0.00909 \\
(0.0268)\end{array}$ & $\begin{array}{c}-0.00323 \\
(0.0269)\end{array}$ \\
\hline Head circumference z-score at birth & & & & $\begin{array}{c}-0.00266 \\
(0.0272)\end{array}$ & $\begin{array}{c}-0.000160 \\
(0.0273)\end{array}$ \\
\hline Thorax circumference at birth z-score & & & & $\begin{array}{c}-0.00540 \\
(0.0314)\end{array}$ & $\begin{array}{l}-0.0151 \\
(0.0300)\end{array}$ \\
\hline Abdomen circumference z-score at birth & & & & $\begin{array}{c}0.0304 \\
(0.0257)\end{array}$ & $\begin{array}{c}0.0222 \\
(0.0266)\end{array}$ \\
\hline Month at first pre-natal visit & & & & & $\begin{array}{c}-0.00831 \\
(0.0127)\end{array}$ \\
\hline Number of Pre-natal visits & & & & & $\begin{array}{c}0.00185 \\
(0.00702)\end{array}$ \\
\hline Prenatal quality $0-10$ & & & & & $\begin{array}{l}0.00363 \\
(0.0129)\end{array}$ \\
\hline Smoked during pregnancy & & & & & $\begin{array}{c}-0.0610 \\
(0.0392)\end{array}$ \\
\hline Constant & $\begin{array}{l}0.00477 \\
(0.0162)\end{array}$ & $\begin{array}{c}0.577 \\
(0.543)\end{array}$ & $\begin{array}{c}0.496 \\
(0.572)\end{array}$ & $\begin{array}{c}0.539 \\
(0.592)\end{array}$ & $\begin{array}{c}0.720 \\
(0.626)\end{array}$ \\
\hline Observations & 3,709 & 3,691 & 3,368 & 3,281 & 3,134 \\
\hline R-squared & 0.004 & 0.009 & 0.022 & 0.023 & 0.021 \\
\hline
\end{tabular}


Table A.13: SDQ internalising scores age 11

\begin{tabular}{|c|c|c|c|c|c|}
\hline VARIABLES & $\begin{array}{c}1) \\
\text { Internal }\end{array}$ & $\begin{array}{c}(2) \\
\text { Internal }\end{array}$ & $\begin{array}{c}(3) \\
\text { Internal } \\
\end{array}$ & $\begin{array}{c}4) \\
\text { Internal }\end{array}$ & $\begin{array}{c}5) \\
\text { Internal }\end{array}$ \\
\hline Family income at birth in log & $\begin{array}{c}0.0701^{* * *} \\
(0.0193)\end{array}$ & $\begin{array}{c}0.0704^{* * *} \\
(0.0195)\end{array}$ & $\begin{array}{c}-0.00237 \\
(0.0205)\end{array}$ & $\begin{array}{c}-0.00100 \\
(0.0209)\end{array}$ & $\begin{array}{l}-0.0153 \\
(0.0214)\end{array}$ \\
\hline Family income at age 11 in $\log$ & $\begin{array}{c}0.182^{* * *} \\
(0.0191)\end{array}$ & $\begin{array}{c}0.173^{* * *} \\
(0.0194)\end{array}$ & $\begin{array}{c}0.0775^{* * *} * \\
(0.0200)\end{array}$ & $\begin{array}{c}0.0752^{* * * *} \\
(0.0203)\end{array}$ & $\begin{array}{c}0.0782^{* * *} \\
(0.0207)\end{array}$ \\
\hline Male & & $\begin{array}{c}0.0975^{* * *} \\
(0.0320)\end{array}$ & $\begin{array}{c}0.120^{* * *} \\
(0.0305)\end{array}$ & $\begin{array}{c}0.111^{* * *} \\
(0.0310)\end{array}$ & $\begin{array}{c}0.102^{* * * *} \\
(0.0315)\end{array}$ \\
\hline Child is black or brown & & $\begin{array}{c}-0.0628^{*} \\
(0.0373)\end{array}$ & $\begin{array}{l}-0.0438 \\
(0.0367)\end{array}$ & $\begin{array}{l}-0.0413 \\
(0.0372)\end{array}$ & $\begin{array}{c}-0.0458 \\
(0.0382)\end{array}$ \\
\hline Age in decimals 2004 & & $\begin{array}{l}-0.0728 \\
(0.0498)\end{array}$ & $\begin{array}{l}-0.0558 \\
(0.0474)\end{array}$ & $\begin{array}{l}-0.0365 \\
(0.0484)\end{array}$ & $\begin{array}{l}-0.0245 \\
(0.0489)\end{array}$ \\
\hline Number of pregnancies 1993 & & $\begin{array}{l}-0.0162 \\
(0.0101)\end{array}$ & $\begin{array}{c}0.0296^{* * *} * \\
(0.0101)\end{array}$ & $\begin{array}{c}0.0270^{* * * *} \\
(0.0103)\end{array}$ & $\begin{array}{r}0.0299 * * * \\
(0.0108)\end{array}$ \\
\hline Lives with husband or partner & & $\begin{array}{c}0.0556 \\
(0.0541)\end{array}$ & $\begin{array}{c}0.0133 \\
(0.0569)\end{array}$ & $\begin{array}{c}0.0218 \\
(0.0576)\end{array}$ & $\begin{array}{c}0.00879 \\
(0.0606)\end{array}$ \\
\hline Mother's education 1993 & & & $\begin{array}{c}0.0335^{* * *} \\
(0.00631)\end{array}$ & $\begin{array}{c}0.0336^{* * * *} \\
(0.00639)\end{array}$ & $\begin{array}{c}0.0331^{* * *} \\
(0.00658)\end{array}$ \\
\hline Father's education 1993 & & & $\begin{array}{c}0.00611 \\
(0.00592)\end{array}$ & $\begin{array}{c}0.00611 \\
(0.00597)\end{array}$ & $\begin{array}{c}0.00644 \\
(0.00609)\end{array}$ \\
\hline Mother psychological index (SQR-20)(-) & & & $\begin{array}{c}0.347^{* * *} \\
(0.0183)\end{array}$ & $\begin{array}{c}0.345^{* * *} \\
(0.0185)\end{array}$ & $\begin{array}{c}0.342^{* * *} \\
(0.0189)\end{array}$ \\
\hline Mother's social activity 2004 & & & $\begin{array}{c}0.00464 \\
(0.00572)\end{array}$ & $\begin{array}{c}0.00456 \\
(0.00573)\end{array}$ & $\begin{array}{c}0.00281 \\
(0.00583)\end{array}$ \\
\hline Mother or father had emotional problems & & & $\begin{array}{c}-0.149^{* * *} \\
(0.0369)\end{array}$ & $\begin{array}{c}-0.154^{* * *} \\
(0.0374)\end{array}$ & $\begin{array}{c}-0.151^{* * *} \\
(0.0378)\end{array}$ \\
\hline Mother's height z-score & & & $\begin{array}{c}0.0136 \\
(0.0174)\end{array}$ & $\begin{array}{c}0.0101 \\
(0.0183)\end{array}$ & $\begin{array}{c}0.0116 \\
(0.0188)\end{array}$ \\
\hline Mother's weight z-score & & & $\begin{array}{c}-0.00204 \\
(0.0176)\end{array}$ & $\begin{array}{c}0.000432 \\
(0.0180)\end{array}$ & $\begin{array}{c}0.00167 \\
(0.0182)\end{array}$ \\
\hline Dubowitz gestational age z-score & & & & $\begin{array}{l}0.00377 \\
(0.0196)\end{array}$ & $\begin{array}{c}0.00641 \\
(0.0201)\end{array}$ \\
\hline Weight z-score at birth & & & & $\begin{array}{l}-0.0430 \\
(0.0361)\end{array}$ & $\begin{array}{c}-0.0459 \\
(0.0367)\end{array}$ \\
\hline Height z-score at birth & & & & $\begin{array}{c}0.0331 \\
(0.0246)\end{array}$ & $\begin{array}{c}0.0338 \\
(0.0248)\end{array}$ \\
\hline Head circumference z-score at birth & & & & $\begin{array}{c}-0.00172 \\
(0.0256)\end{array}$ & $\begin{array}{c}-0.000516 \\
(0.0261)\end{array}$ \\
\hline Thorax circumference at birth z-score & & & & $\begin{array}{l}0.00451 \\
(0.0341)\end{array}$ & $\begin{array}{c}0.0114 \\
(0.0342)\end{array}$ \\
\hline Abdomen circumference z-score at birth & & & & $\begin{array}{c}0.0380 \\
(0.0245)\end{array}$ & $\begin{array}{c}0.0305 \\
(0.0252)\end{array}$ \\
\hline Month at first pre-natal visit & & & & & $\begin{array}{r}-0.00357 \\
(0.0113)\end{array}$ \\
\hline Number of Pre-natal visits & & & & & $\begin{array}{c}-0.00201 \\
(0.00634)\end{array}$ \\
\hline Prenatal quality $0-10$ & & & & & $\begin{array}{c}0.0169 \\
(0.0117)\end{array}$ \\
\hline Smoked during pregnancy & & & & & $\begin{array}{c}-0.102 * * * \\
(0.0364)\end{array}$ \\
\hline Constant & $\begin{array}{c}0.0166 \\
(0.0160)\end{array}$ & $\begin{array}{c}0.800 \\
(0.568)\end{array}$ & $\begin{array}{c}0.254 \\
(0.544)\end{array}$ & $\begin{array}{l}0.0444 \\
(0.555)\end{array}$ & $\begin{array}{l}-0.132 \\
(0.572)\end{array}$ \\
\hline Observations & 3,689 & 3,671 & 3,349 & 3,264 & 3,120 \\
\hline R-squared & 0.052 & 0.057 & 0.208 & 0.210 & 0.213 \\
\hline
\end{tabular}


Table A.14: SDQ externalising scores age 11

\begin{tabular}{|c|c|c|c|c|c|}
\hline VARIABLES & $\begin{array}{c}(1) \\
\text { External }\end{array}$ & $\begin{array}{c}(2) \\
\text { External }\end{array}$ & $\begin{array}{c}(3) \\
\text { External }\end{array}$ & $\begin{array}{c}(4) \\
\text { External }\end{array}$ & $\begin{array}{c}(5) \\
\text { External }\end{array}$ \\
\hline Family income at birth in log & $\begin{array}{c}0.132^{* * * *} \\
(0.0186)\end{array}$ & $\begin{array}{c}0.124^{* * *} \\
(0.0185)\end{array}$ & $\begin{array}{c}0.0675 * * * \\
(0.0200)\end{array}$ & $\begin{array}{c}0.0614^{* * *} \\
(0.0203)\end{array}$ & $\begin{array}{c}0.0558^{* * * *} \\
(0.0207)\end{array}$ \\
\hline Family income at age 11 in log & $\begin{array}{c}0.102^{* * *} \\
(0.0196)\end{array}$ & $\begin{array}{c}0.0886^{* * *} \\
(0.0197)\end{array}$ & $\begin{array}{c}-0.00269 \\
(0.0213)\end{array}$ & $\begin{array}{c}-0.00290 \\
(0.0216)\end{array}$ & $\begin{array}{l}-0.0126 \\
(0.0223)\end{array}$ \\
\hline Male & & $\begin{array}{c}-0.289 * * * \\
(0.0317)\end{array}$ & $\begin{array}{c}-0.273^{* * *} \\
(0.0316)\end{array}$ & $\begin{array}{c}-0.270^{* * *} \\
(0.0322)\end{array}$ & $\begin{array}{c}-0.276^{* * *} \\
(0.0327)\end{array}$ \\
\hline Child is black or brown & & $\begin{array}{c}-0.101^{* * * *} \\
(0.0364)\end{array}$ & $\begin{array}{c}-0.0853^{* *} \\
(0.0370)\end{array}$ & $\begin{array}{c}-0.0706^{*} \\
(0.0376)\end{array}$ & $\begin{array}{c}-0.0653^{*} \\
(0.0389)\end{array}$ \\
\hline Age in decimals 2004 & & $\begin{array}{c}-0.0641 \\
(0.0484)\end{array}$ & $\begin{array}{l}-0.0522 \\
(0.0485)\end{array}$ & $\begin{array}{l}-0.0387 \\
(0.0497)\end{array}$ & $\begin{array}{l}-0.0481 \\
(0.0504)\end{array}$ \\
\hline Number of pregnancies 1993 & & $\begin{array}{c}-0.0319 * * * \\
(0.00997)\end{array}$ & $\begin{array}{l}0.00388 \\
(0.0105)\end{array}$ & $\begin{array}{c}0.000570 \\
(0.0106)\end{array}$ & $\begin{array}{l}0.00881 \\
(0.0112)\end{array}$ \\
\hline Lives with husband or partner & & $\begin{array}{c}0.217^{* * *} \\
(0.0542)\end{array}$ & $\begin{array}{c}0.195^{* * *} \\
(0.0599)\end{array}$ & $\begin{array}{c}0.204^{* * *} \\
(0.0612)\end{array}$ & $\begin{array}{c}0.172^{* * *} \\
(0.0653)\end{array}$ \\
\hline Mother's education 1993 & & & $\begin{array}{c}0.0174^{* * *} \\
(0.00627)\end{array}$ & $\begin{array}{c}0.0170^{* * *} \\
(0.00633)\end{array}$ & $\begin{array}{l}0.0149 * * \\
(0.00652)\end{array}$ \\
\hline Father's education 1993 & & & $\begin{array}{l}0.0136^{* *} \\
(0.00590)\end{array}$ & $\begin{array}{l}0.0147^{* *} \\
(0.00595)\end{array}$ & $\begin{array}{l}0.0139 * * \\
(0.00602)\end{array}$ \\
\hline Mother psychological index (SQR-20)(-) & & & $\begin{array}{c}0.267^{* * *} \\
(0.0191)\end{array}$ & $\begin{array}{c}0.265^{* * *} \\
(0.0194)\end{array}$ & $\begin{array}{c}0.256^{* * *} \\
(0.0198)\end{array}$ \\
\hline Mother's social activity 2004 & & & $\begin{array}{c}0.0244^{* * *} \\
(0.00626)\end{array}$ & $\begin{array}{c}0.0241^{* * *} \\
(0.00639)\end{array}$ & $\begin{array}{c}0.0230 * * * \\
(0.00655)\end{array}$ \\
\hline Mother or father had emotional problems & & & $\begin{array}{c}-0.134^{* * *} \\
(0.0380)\end{array}$ & $\begin{array}{c}-0.133^{* * *} \\
(0.0387)\end{array}$ & $\begin{array}{c}-0.140 * * * \\
(0.0394)\end{array}$ \\
\hline Mother's height z-score & & & $\begin{array}{c}0.0181 \\
(0.0179)\end{array}$ & $\begin{array}{l}0.00910 \\
(0.0188)\end{array}$ & $\begin{array}{c}-0.000173 \\
(0.0191)\end{array}$ \\
\hline Mother's weight z-score & & & $\begin{array}{c}-0.000664 \\
(0.0178)\end{array}$ & $\begin{array}{l}0.00457 \\
(0.0181)\end{array}$ & $\begin{array}{c}0.0168 \\
(0.0185)\end{array}$ \\
\hline Dubowitz gestational age z-score & & & & $\begin{array}{c}-0.00795 \\
(0.0207)\end{array}$ & $\begin{array}{c}-0.00764 \\
(0.0213)\end{array}$ \\
\hline Weight z-score at birth & & & & $\begin{array}{l}-0.0254 \\
(0.0366)\end{array}$ & $\begin{array}{l}-0.0265 \\
(0.0372)\end{array}$ \\
\hline Height z-score at birth & & & & $\begin{array}{l}0.00994 \\
(0.0235)\end{array}$ & $\begin{array}{l}0.00259 \\
(0.0236)\end{array}$ \\
\hline Head circumference z-score at birth & & & & $\begin{array}{c}0.0269 \\
(0.0277)\end{array}$ & $\begin{array}{c}0.0302 \\
(0.0283)\end{array}$ \\
\hline Thorax circumference at birth z-score & & & & $\begin{array}{r}-0.00878 \\
(0.0316)\end{array}$ & $\begin{array}{r}-0.00657 \\
(0.0317)\end{array}$ \\
\hline Abdomen circumference z-score at birth & & & & $\begin{array}{c}0.0399 \\
(0.0245)\end{array}$ & $\begin{array}{c}0.0258 \\
(0.0251)\end{array}$ \\
\hline Month at first pre-natal visit & & & & & $\begin{array}{r}-0.00929 \\
(0.0116)\end{array}$ \\
\hline Number of Pre-natal visits & & & & & $\begin{array}{c}0.00539 \\
(0.00622)\end{array}$ \\
\hline Prenatal quality $0-10$ & & & & & $\begin{array}{l}0.00388 \\
(0.0120)\end{array}$ \\
\hline Smoked during pregnancy & & & & & $\begin{array}{c}-0.172^{* * *} \\
(0.0374)\end{array}$ \\
\hline Constant & $\begin{array}{c}0.0132 \\
(0.0161)\end{array}$ & $\begin{array}{c}0.796 \\
(0.550)\end{array}$ & $\begin{array}{c}0.240 \\
(0.558)\end{array}$ & $\begin{array}{l}0.0784 \\
(0.571)\end{array}$ & $\begin{array}{c}0.234 \\
(0.592)\end{array}$ \\
\hline Observations & 3,686 & 3,670 & 3,351 & 3,265 & 3,119 \\
\hline R-squared & 0.042 & 0.072 & 0.166 & 0.166 & 0.171 \\
\hline
\end{tabular}




\section{B}

\section{Chapter 2 - Additional results}

Figure B.1: Distribution of latent variables
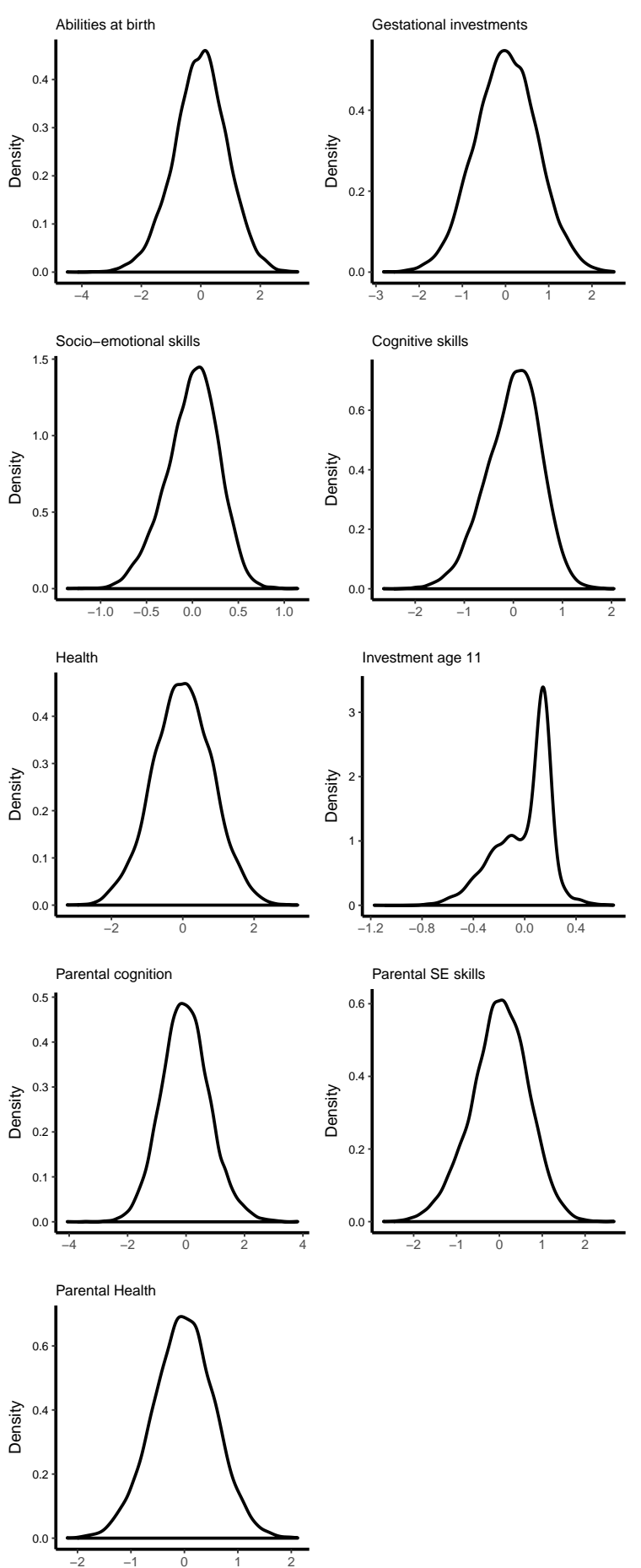
Table B.1: Endogenous CES Production function of children's abilities

\begin{tabular}{lcccc}
\hline \hline & Abilities at birth & Cognition & Socio-emotional & Health \\
& $(1)$ & $(2)$ & $(3)$ & $(4)$ \\
\hline Parental investment & 0.332 & 0.398 & 0.630 & 0.210 \\
& $(0.276,0.549)$ & $(0.226,0.490)$ & $(0.586,0.805)$ & $(0.120,0.262)$ \\
Ability at birth & & 0.015 & 0.010 & 0.074 \\
& & $(0.001,0.040)$ & $(-0.002,0.031)$ & $(0.033,0.116)$ \\
Parental Cognition & -0.045 & 0.188 & 0.045 & 0.085 \\
& $(-0.214,0.034)$ & $(0.127,0.399)$ & $(0.005,0.074)$ & $(0.047,0.154)$ \\
Parental socio-emotional skills & 0.111 & 0.373 & 0.251 & 0.058 \\
& $(0.054,0.189)$ & $(0.320,0.451)$ & $(0.126,0.300)$ & $(0.016,0.145)$ \\
Parental health & 0.602 & 0.025 & 0.063 & 0.573 \\
& $(0.499,0.644)$ & $(-0.089,0.039)$ & $(0.011,0.092)$ & $(0.479,0.620)$ \\
CES coefficient & -0.076 & -0.060 & 0.118 & -0.090 \\
& $(-0.251,0.046)$ & $(-0.117,0.016)$ & $(-0.050,0.415)$ & $(-0.235,0.021)$ \\
Controls & Yes & Yes & Yes & Yes \\
\hline \hline
\end{tabular}

$95 \%$ confidence intervals based on 100 bootstrap replications in parenthesis 
Table B.2: Nested CES Production function of children's abilities

\begin{tabular}{lcccc}
\hline \hline & Abilities at birth & Cognition & Socio-emotional & Health \\
& $(1)$ & $(2)$ & $(3)$ & $(4)$ \\
\hline Parental investment & 0.577 & 0.377 & 0.767 & $(0.066,0.248)$ \\
& $(0.407,0.745)$ & $(0.163,0.500)$ & $(0.661,0.934)$ & 0.078 \\
Abilities at birth & & 0.017 & -0.002 & $(0.032,0.118)$ \\
& & $(0.002,0.047)$ & $(-0.012,0.016)$ & 0.756 \\
Share of joint parental skills & 0.423 & 0.606 & 0.235 & $(0.658,0.868)$ \\
& $(0.255,0.593)$ & $(0.483,0.812)$ & $(0.063,0.329)$ & 0.125 \\
Parental Cognition & -0.410 & 0.318 & 0.088 & $(0.075,0.200)$ \\
& $(-1.052,-0.134)$ & $(0.261,0.570)$ & $(-0.191,0.218)$ & 0.092 \\
Parental socio-emotional skills & 0.156 & 0.628 & 0.854 & $(0.040,0.185)$ \\
& $(0.032,0.416)$ & $(0.508,0.732)$ & $(0.765,1.318)$ & 0.783 \\
Parental health & 1.254 & 0.054 & 0.058 & $(0.672,0.856)$ \\
Investment residual & $(0.931,1.967)$ & $(-0.104,0.086)$ & $(-0.154,0.196)$ & 0.189 \\
CES coefficient & -0.297 & 0.094 & -0.603 & $(-0.066,0.341)$ \\
& $(-0.463,-0.078)$ & $(-0.076,0.505)$ & $(-0.864,-0.372)$ & 0.303 \\
CES internal coefficient & -0.097 & -0.206 & -0.097 & $(0.131,0.652)$ \\
& $(-0.228,0.023)$ & $(-0.524,-0.057)$ & $(-0.180,0.060)$ & -0.308 \\
Controls & -0.111 & 0.013 & 0.275 & $(-0.525,-0.142)$ \\
\hline \hline
\end{tabular}

$95 \%$ confidence intervals based on 100 bootstrap replications in parenthesis 
C

\section{Chapter 3 - Additional results}

\section{C.1}

\section{Chile Crece Contigo}

The following table shows statistics of ChCC activities among beneficiaries in the public health system. The activities with the highest coverage are educational sessions.

Table C.1: ChCC Statistics

\begin{tabular}{lccccc}
\hline \hline & 2008 & 2009 & 2010 & 2011 & 2012 \\
\hline $\begin{array}{l}\text { Pregnant women with psycho-social evaluation } \\
\text { (in percentage) }\end{array}$ & & 92.0 & 88.3 & 96.7 & 97.1 \\
$\begin{array}{l}\text { Pregnant women with psycho-social risk (in } \\
\text { percentage) }\end{array}$ & 28.1 & 35.9 & 34.2 & 38.1 & 38.2 \\
$\begin{array}{l}\text { Home visits per pregnant women with psycho- } \\
\text { social risks }\end{array}$ & 0.9 & 0.9 & 1.1 & 1.1 & 1.2 \\
$\begin{array}{l}\text { Participants of group educational sessions on } \\
\text { pregnancy topics per pregnant women }\end{array}$ & 0.7 & 0.9 & 1.2 & 1.1 & 1.3 \\
\hline $\begin{array}{l}\text { Children under two with psychomotor evalua- } \\
\text { tion (in percentage) }\end{array}$ & 79.5 & 80.7 & 87.0 & 88.8 \\
$\begin{array}{l}\text { Children aged 24 to 47 months with psychomo- } \\
\text { tor evaluation (in percentage) }\end{array}$ & & 32.0 & 28.8 & 31.4 & 33.0 \\
$\begin{array}{l}\text { Evaluated children with developmental deficits } \\
\text { under treatment (in percentage) }\end{array}$ & 6.4 & 6.4 & 6.6 & 6.3 & 5.7 \\
$\begin{array}{l}\text { Home visits per children with developmental } \\
\text { deficits }\end{array}$ & 0.3 & 0.8 & 1.1 & 1.3 & 1.7 \\
$\begin{array}{l}\text { Participants of group educational sessions on } \\
\text { parenting per children under six }\end{array}$ & 0.3 & 0.3 & 0.4 & 0.4 & 0.4 \\
\hline \hline Source: DEIS 2008-2012 & & & & & \\
\hline
\end{tabular}


Table C.2: 2010 Descriptive Statistics - Socio-demographic characteristics

\begin{tabular}{lccc}
\hline \hline & \multicolumn{3}{c}{ 18-23 months } \\
\cline { 2 - 4 } & pre-ChCC & post-ChCC & P-val \\
\hline Working memory & 0.02 & -0.05 & 0.21 \\
Vocabulary & 0.07 & 0.15 & 0.18 \\
Mother education & 10.56 & 10.62 & 0.81 \\
Father education & 10.55 & 10.76 & 0.28 \\
Height & -0.01 & -0.00 & 0.90 \\
Weight & -0.09 & -0.15 & 0.43 \\
Gestation in weeks & 0.02 & 0.09 & 0.11 \\
Birth height & -0.06 & 0.00 & 0.25 \\
Birth weight & 0.02 & -0.04 & 0.35 \\
Sex of the child & 0.50 & 0.49 & 0.86 \\
Main caregiver's age & 27.55 & 27.61 & 0.81 \\
Minors < 7 & 1.43 & 1.45 & 0.65 \\
Minors $>7$ & 0.78 & 0.77 & 0.95 \\
Parents live together & 0.62 & 0.64 & 0.74 \\
Per capita income & 11.10 & 11.06 & 0.41 \\
\hline Observations & 904 & 469 & 1300 \\
\hline \hline Source: ELPI 2010 & &
\end{tabular}

Table C.3: 2012 Descriptive Statistics - Socio-demographic characteristics

\begin{tabular}{lccc}
\hline \hline & \multicolumn{3}{c}{$36-47$ months } \\
\cline { 2 - 4 } & pre-ChCC & post-ChCC & P-val \\
\hline Working memory & 0.10 & -0.01 & 0.11 \\
Vocabulary & 0.05 & 0.05 & 0.99 \\
Mother education & 11.10 & 11.01 & 0.55 \\
Father education & 11.07 & 10.89 & 0.29 \\
Height & -0.01 & 0.01 & 0.75 \\
Weight & 0.09 & 0.05 & 0.44 \\
Gestation in weeks & -0.01 & 0.00 & 0.77 \\
Birth height & -0.05 & -0.05 & 0.99 \\
Birth weight & -0.01 & -0.03 & 0.83 \\
Sex of the child & 0.51 & 0.51 & 0.93 \\
Main caregiver's age & 29.56 & 29.64 & 0.83 \\
Minors < 7 & 1.43 & 1.41 & 0.50 \\
Minors $>7$ & 0.78 & 0.77 & 0.85 \\
Parents live together & 0.63 & 0.64 & 0.66 \\
Per capita income & 11.30 & 11.32 & 0.57 \\
\hline Observations & 451 & 2066 & 2269 \\
\hline \hline Source: ELPI 2012 & & &
\end{tabular}


Figure C.1: Distribution of latent variables - Age 18-23 months
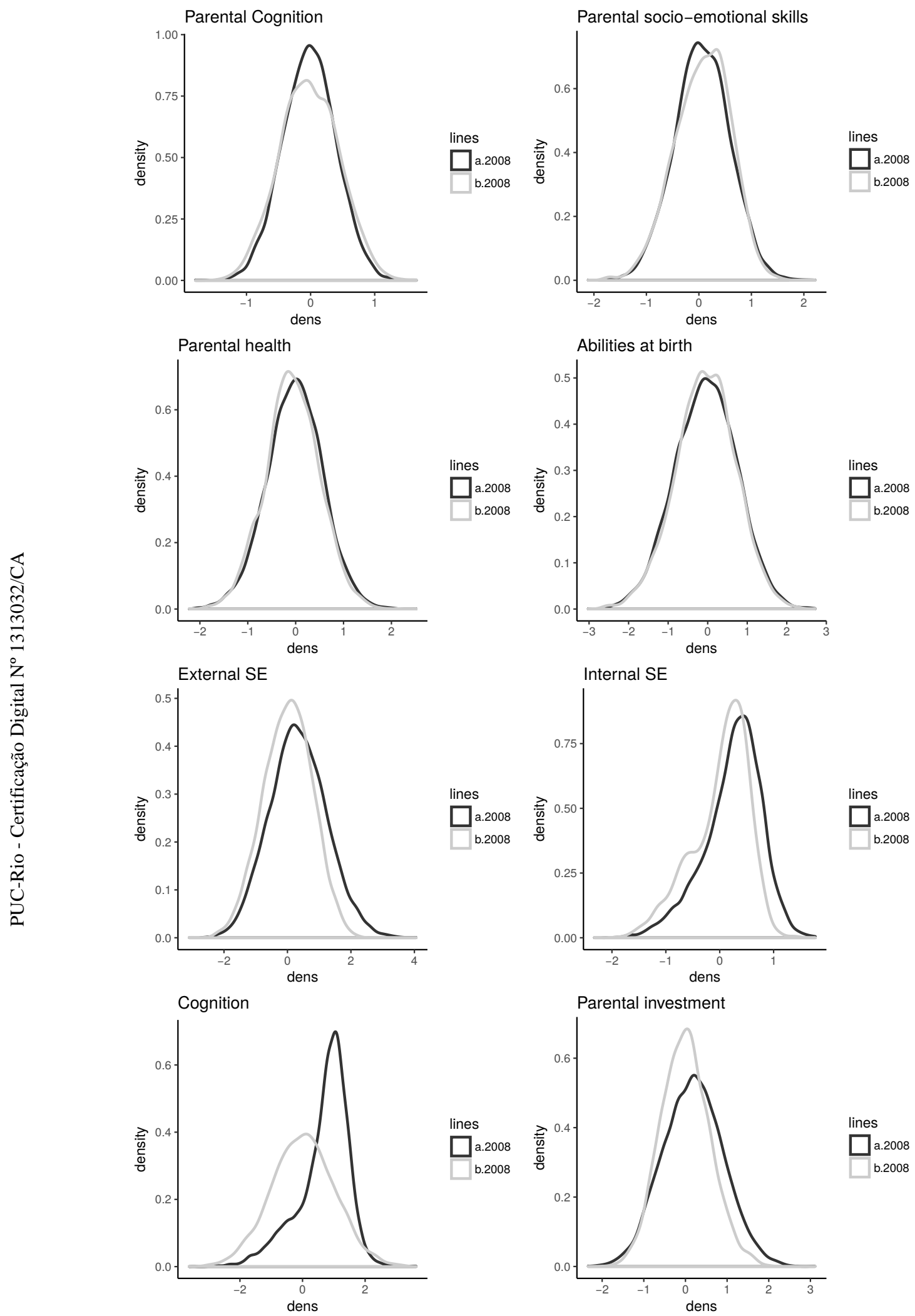

Source: Own elaboration based on EM results 
Figure C.2: Distribution of latent variables - Age 36-47 months
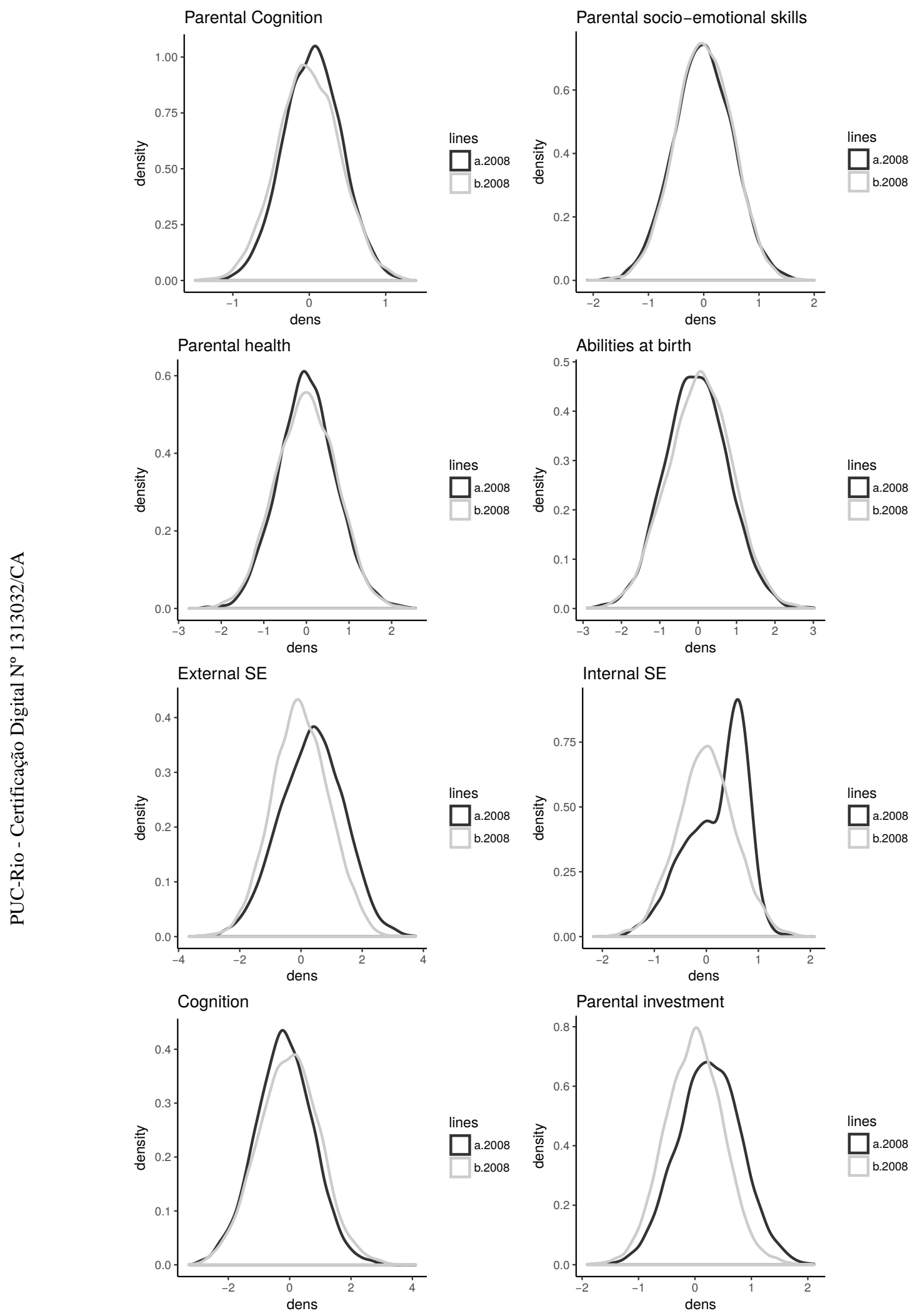

Source: Own elaboration based on EM results 